\title{
An ancient Kurdish Religion: Yarsan
}

\section{Zrian Jazni Mohammed ${ }^{1}$}

Received: Nov23, 2017 Reviewed: Feb23, 2018

Accepted: May13, 2018

\section{Abstract}

Yarsan is an ancient Kurdish Religion; it is based on the other old religions in Kurdistan such as Metrayi and Zardashti. (Saranjam) is the holy book of Yarsan Religion. Yarsan is considered as part of Kurdish national heritage and has its own particular secular ceremonies; it could continuously develop and renew itself.

In this thesis, we try to throw light on women class in the aspect of writing, music and religious education in Yarsan Religion along history, To enrich this subject more, we have referred to the wellknown cultured women mentioned in the holy book (Saranjam); those women held high position in community and whose poems were interpreted and played their role side by side with men to serve and circulate the message of Yarsan Religion and educating the people.

Keywords:Yarsan, Religion, Zardashti, Metrayi, Ancient religion

\section{Recommended citation:}

Mohammed,Z. J. (2018). An ancient Kurdish Religion: Yarsan. International Journal of Kurdish Studies 4 (2), 595-624. doi: 10.21600/ ijoks.454576

\footnotetext{
${ }^{1}$ Ph.D Candidate, University of Salahaddin, KRG, Iraq. E-mail: semaako75@gmail.com
} 


\author{
زن له ئايينى يارسان \\ زريان جيزنى محهمهد

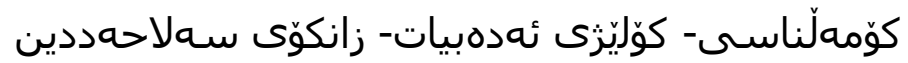

يوخته

ئايينى يارسان ئايينيّكى كوردييهو و لهسهر بنهماى نايينه ديّريينهكانى كوردستان وهك ميترايى و زهردهشتى و ئايينه كانى تر رهنكُريّزكراوه و(سهرنجام)، كتابى ييروّزى ئايينى يارسانه . ئايينى

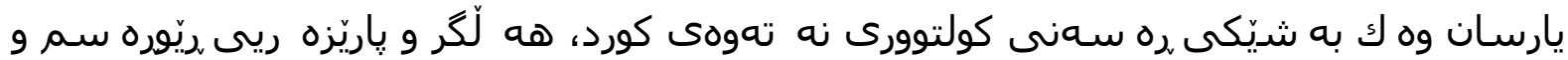

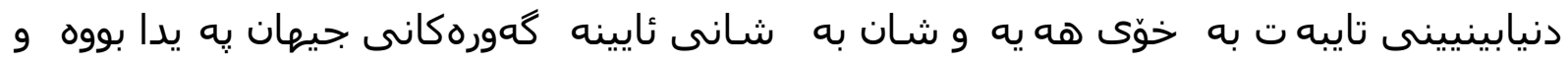
كَشـى سـنهووه و خوّى نويّكردووهتهوه.

لهم تويزرينه وهدا تيشك ده خهينه سهر ده ور و بِيّكَ ى زن له بوارى نووسين و موّسيقا و ئايين

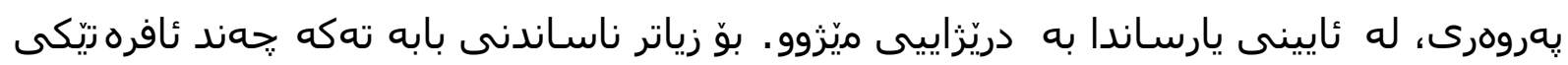

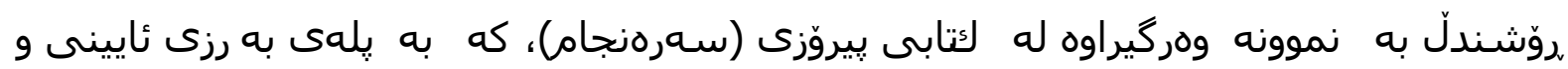

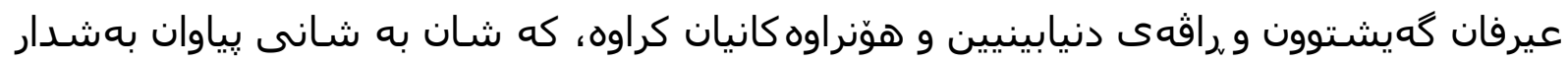

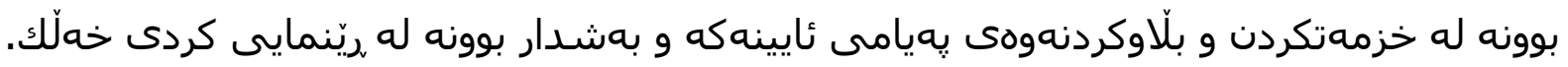

رِيِشهَى

ناسنامهى هه ر نه تهوهيهك بريتييه له سهرجهمى تايبه تكارهكانى كولتووره مادى و

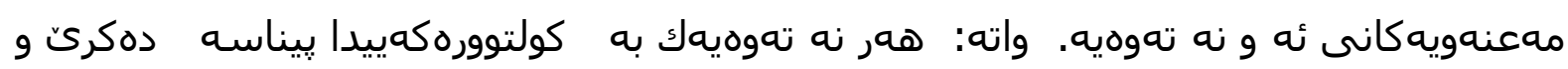
دهناسريّتوه. ئهگهر نا، مروّث له ههموو جيهاندا ههر مروّقن و، ئهوهى لهيهك جيايان ده كاتهوه،

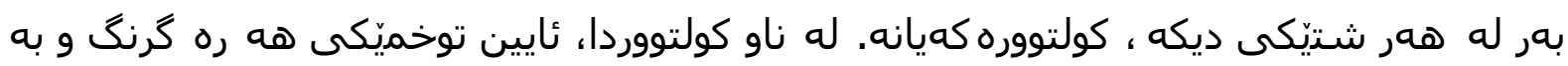

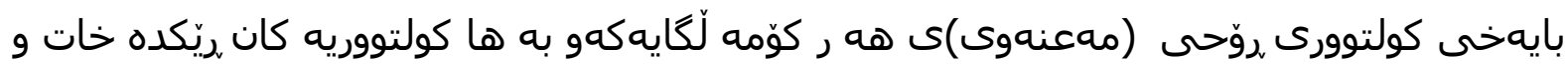

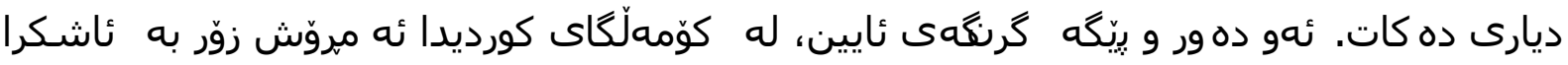
بهرجهسته بووه، به رادهيهك كه لههمموو بوارهكانى زيانى كولتوورى و ئاسايى ئه ندامانى

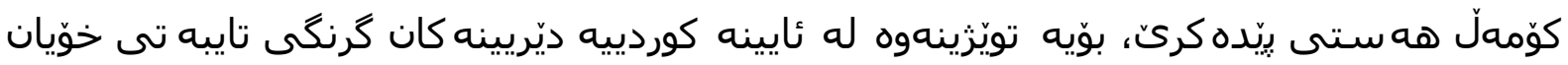

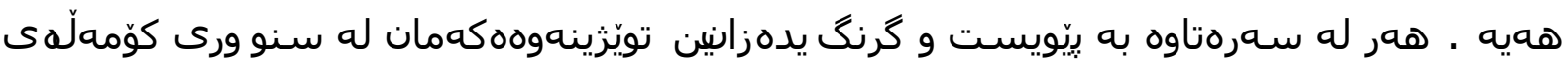

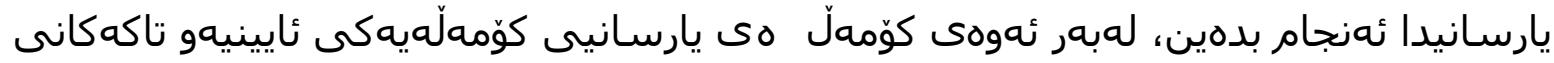

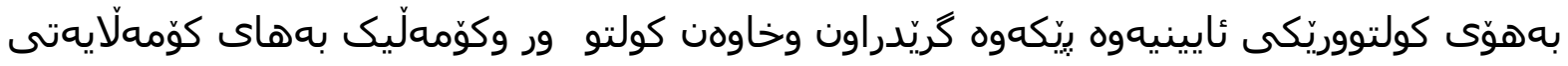

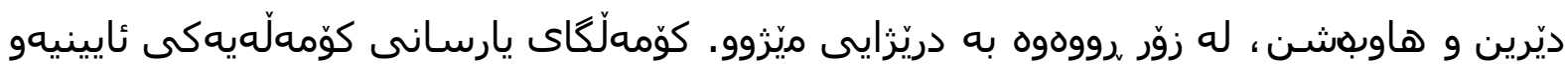




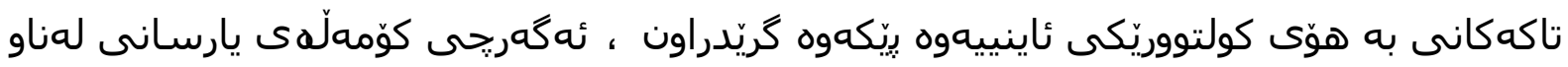

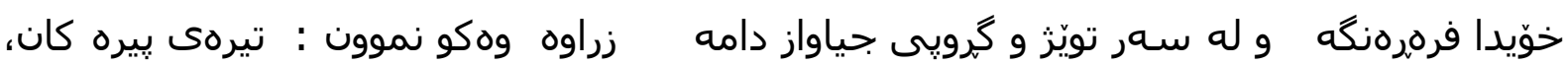

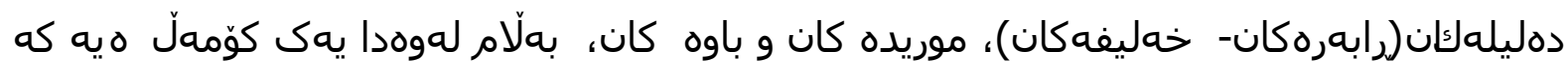
يهيرهوى له هممان ئاييندهكهن، ئهو كولتووره ديّرينهش كولتوورى ئايينكى يارسانه.

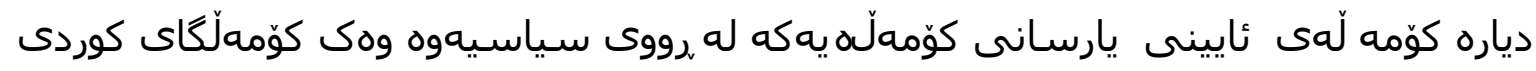

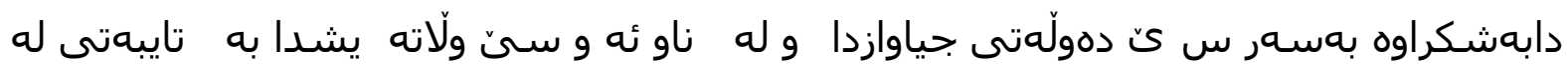

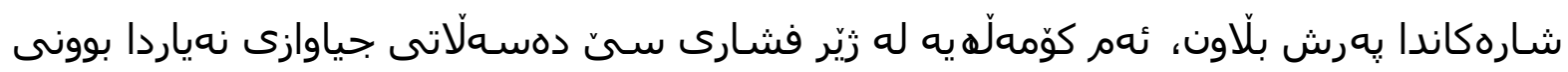

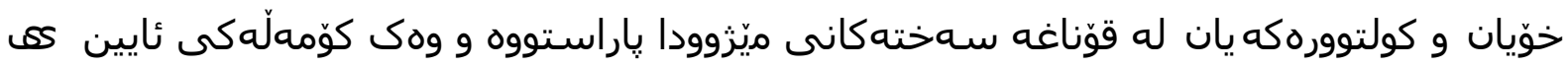
خاوهن موّركى تايبهتى خوّيان، توانيووكلنه ياريّزگارى له خوّيان بكهن. لهم تويّزينه وهدا تيشك ده خهينه سهر بِيككاتى ئايينى يارسان (كاكهيى)، كه ئيينيّكى كورديى

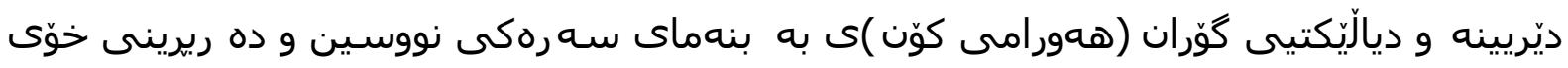

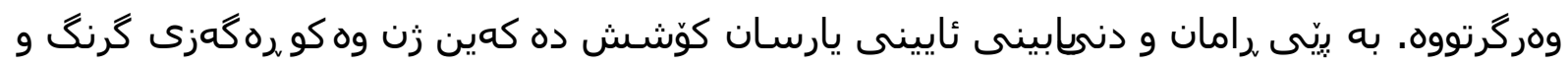

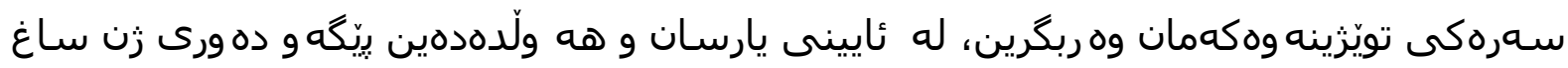

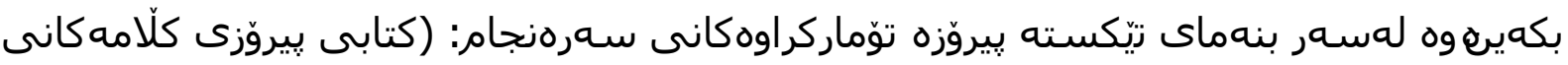

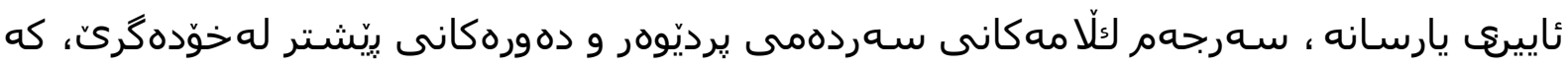

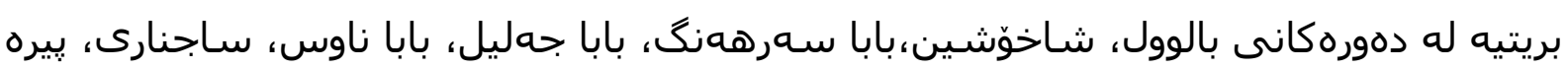

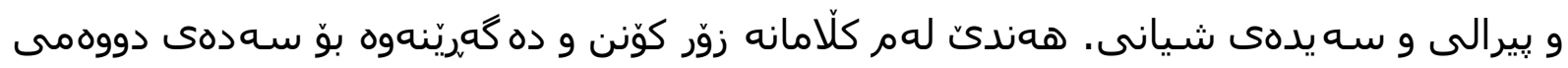
كوّيحى).

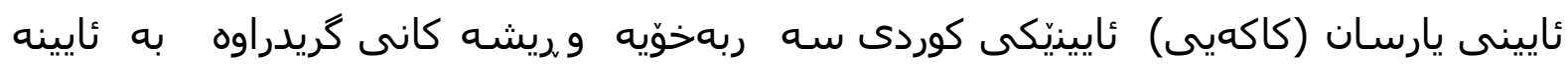

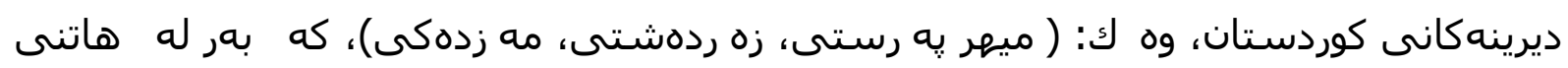

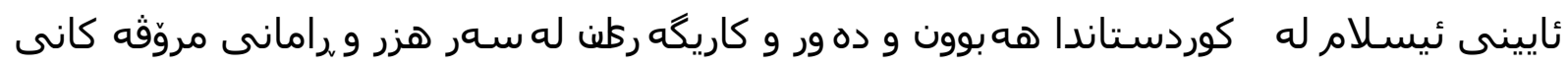

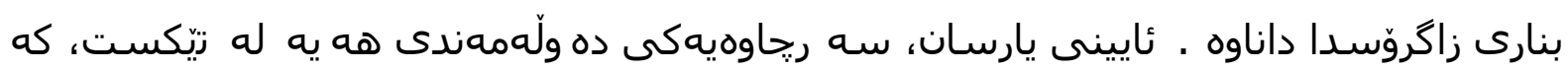
بهشيّكى باشـى له (سهرهنجام) كوّكراوهتهوه، كه بريتيه له فهرموودهكانى سولّتان سه هاك و

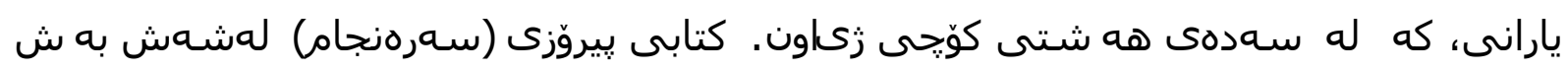
ريّكبهاتووه:

بارگه بارگه، ده ورى هه فتهوانه، كليم و كوّل، ده ورهى يُلّه ن، ده ورهى نابدين و ورده

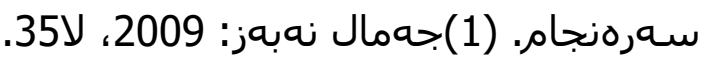

كلامهكانى ئايينى يارسان وه كو هه موو ئه دهبياتى ئايينى به دريّزايى دروّزَار ده وره به دوواى

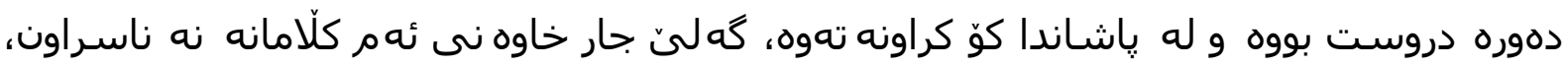

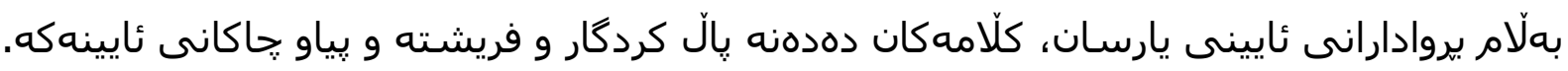

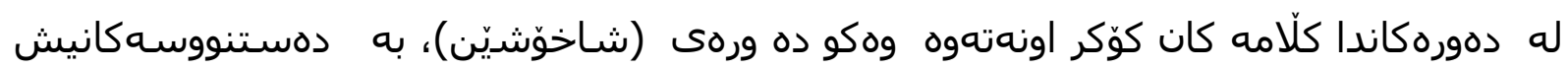
دهلّين(دهفتصر). 


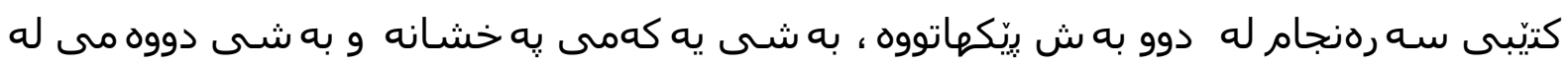

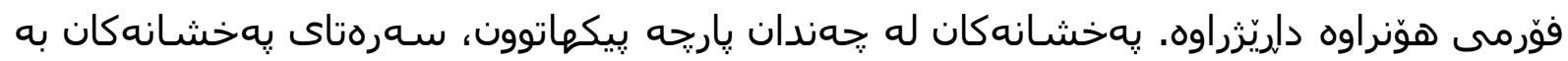
دروست بوونى (بوون- كهردوون)دهست بِيدهذكا، خوو و ،رهووشت و رهسم و عادهتى يارسانهكان

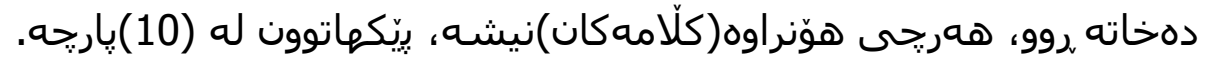

(2) مارف خهزنهدار:2010، ل254.

له سهردهمى سولّتان سه هاك، ئايينى يارسان ئاسوّيه كى به رينتر و بالاترى به خوّيهوه كرت،

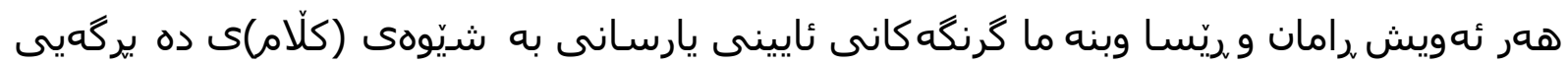

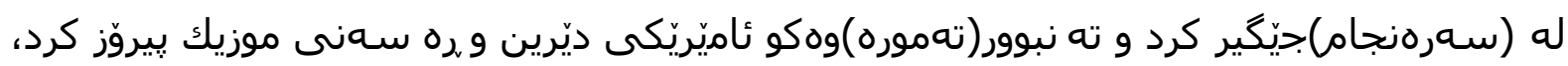

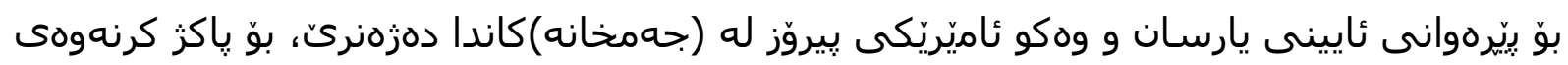

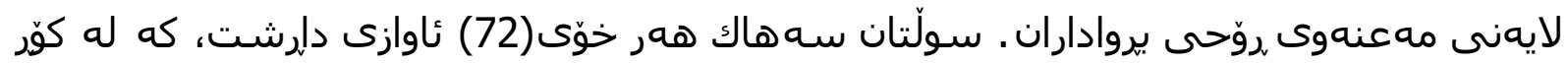

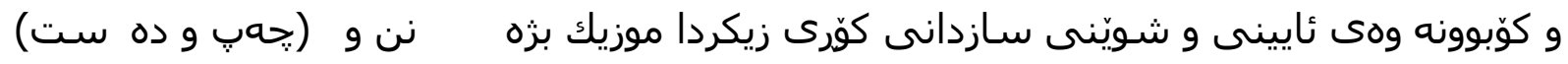

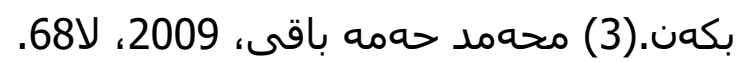

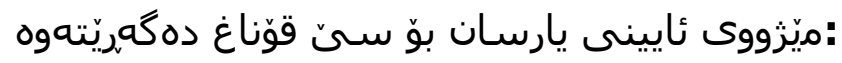

1. قوّناغى ناديار و كهسـهزان، كه دوّرَى خهلّقهتى جيهانه.

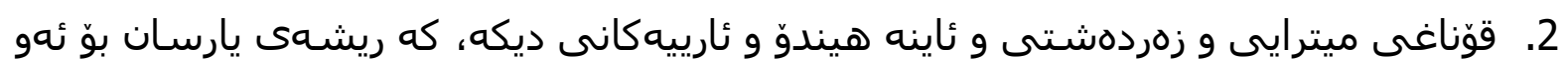

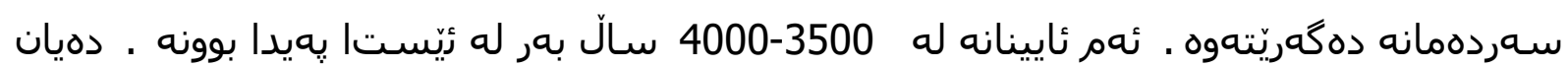

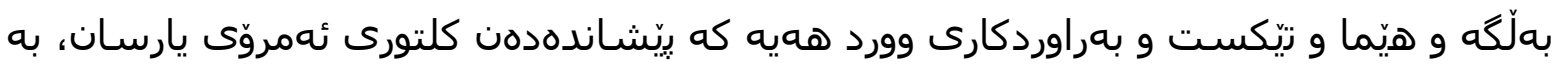
ئهسل و ريشه و فهلسهفووه، بوّ سهردهمانى ئايينى زهروانى و ميترايى و زهردهشتى و و مانى و ئهوانى ديكه دهگهريتهوه، وهههرهوهها زيّكهلاوى كلتورى ئاينى هيندوّسى و ب وودايى بوه له روّرَهمَلات.

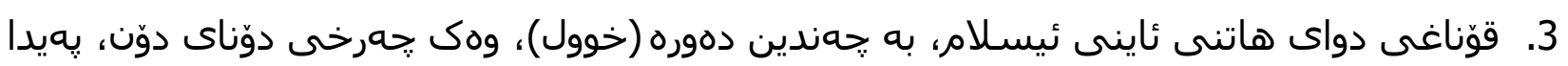

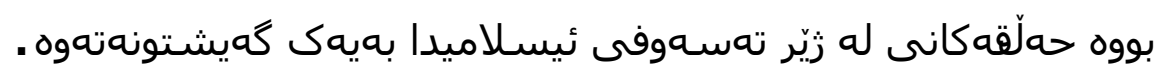

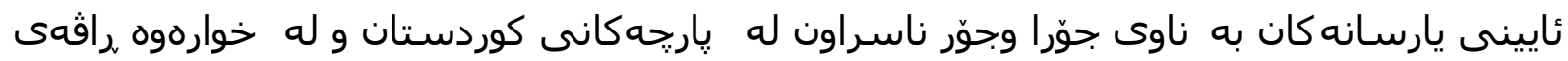
ئهو ناوانه دهكهين كه رِيِى ناسراون وه ك: (كاكهيى، ئههلى حهق، يارسان)، كه خوّشيان ئهم ناوانهيان قبولّه:

كرنكى تويّزينهوهكه

لهم تويزينهوهيهدا دهمانهوك تيشك بخه ينه سهر رن له ئايينى يارسان، كه كرنگه ئاشنابين به لورينه

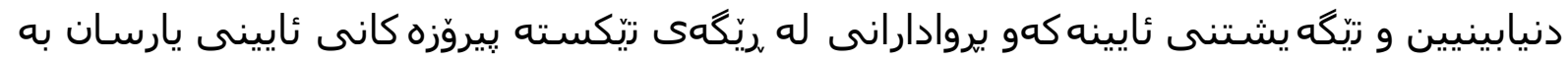

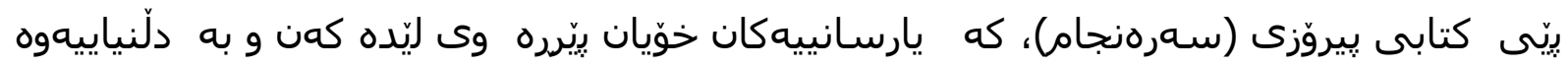

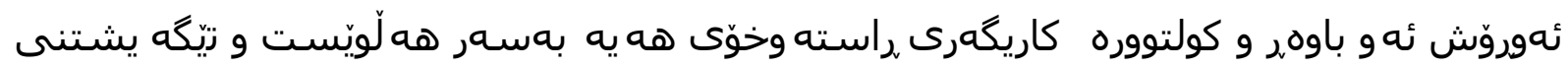


يروادارانى ئايينى يارسان و كولتوورى كوّمه لّكاى كوردى، ده ربارهى ئازادى و يِيّكَه و ده ور و ريزكرتنى ئافرهت.

:

له ئاوِيسـتادا كائاكا، كهئاكه، و كائهكا، وهكو ناو و ناوهلّناو بوّ زيّرو من بهكارهاتون كه واتاى

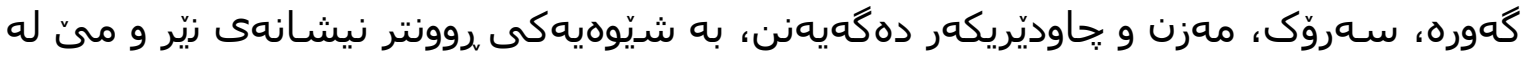

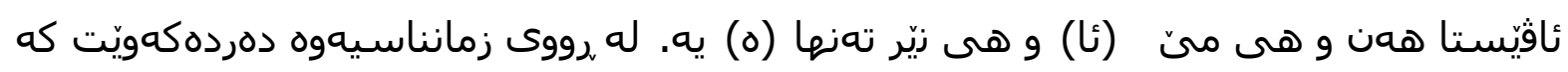
(يى) نسبه پِوّته ياشتكرى وشـهى (كاكه) وه و بووه به (كاكهيى).

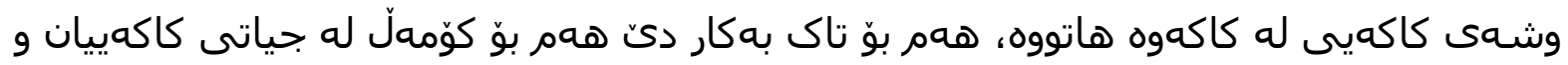

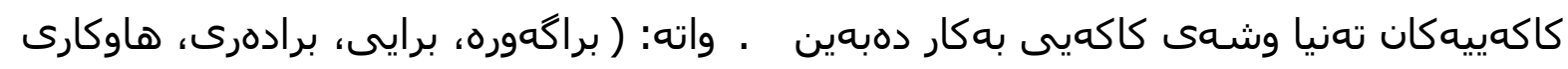

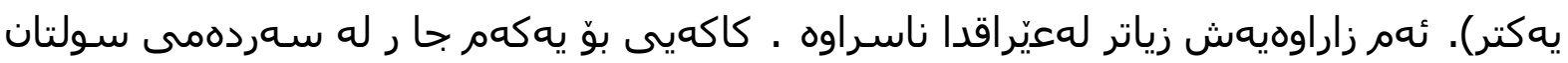
سههاكدا هاتوّته كايهوه، ييش ئوسـا به يارسـان ناسراوه وه ناوه ناوهش به (ئهلى حهق) و و تايفه ناو براون. (4) فهلكهدين، 2009، لاهوه

ئهمش ئهو كهلامانهيه كه له سهردهمى يرديوهر و سـولّان سههاكدا كُتراون و ئهم

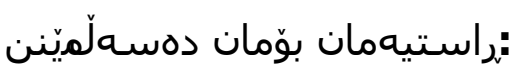

كاكوو كاكهييان نهزم خاوهندكار

عaبدرو گ كاكى ناميّما توَمار

واته: (كاكهو كاكهييهان له ئامادهردن و ريّكخستنى خاوهندكاره، بهندهى ههموو كاكهييهم و

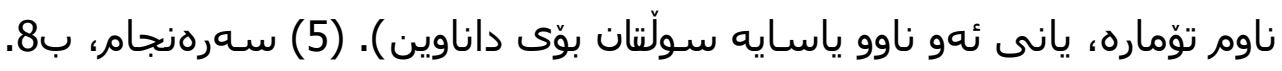

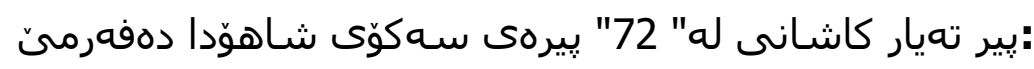

دوّن وه دوّن ئامايم يَّى وهرهو كاكان

واته: دوّن به دوّن هاتين بهرهو لاى كاكهييهان. (6) سهرهنجام، ب4.

وازهى كاكهيى هيج كاتيّك به ماناى خيّل و عهشيرهت نايهت، همنديّك دبيزرن كه كاكهيى ناوه

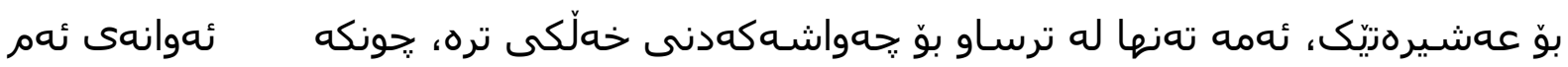

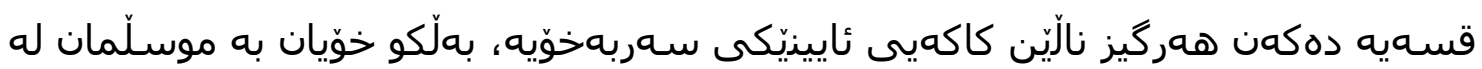
قلّمر دهدهن وههنديّكيان خوّيان بهلاى مهزههبى سونه و ههنديّكى تر خوّيان به لايهنكرى

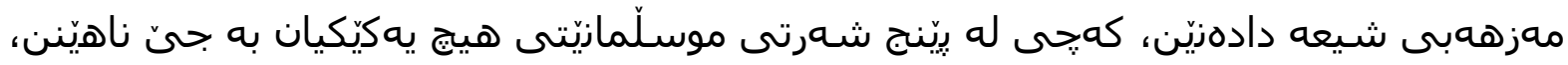

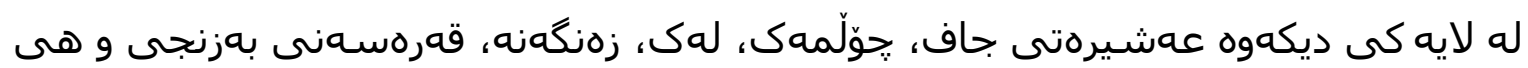

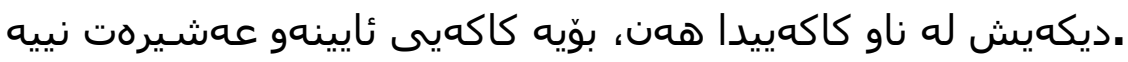

دووهمر: وازمى (ئهلى حهق). 
له دوو لايهنهوه به كاكهيى دهلّين، يهكيّك ئهوهيه كه وازرى (حهق) همميشه له ناو بهيازهكانى

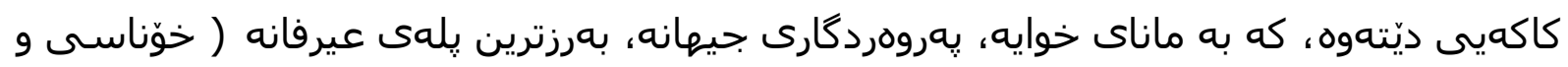

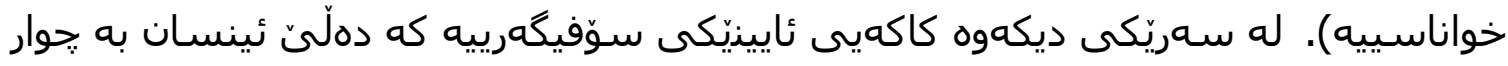

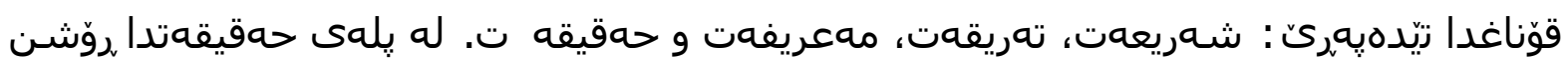

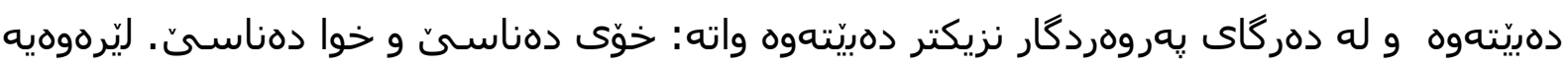

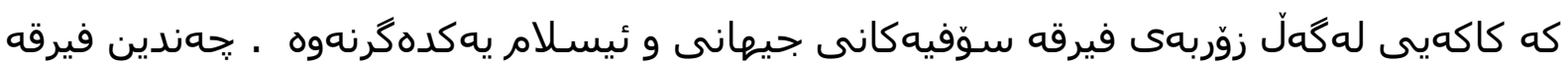

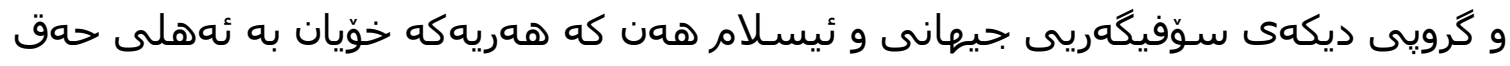

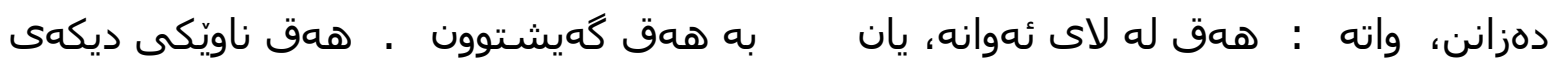

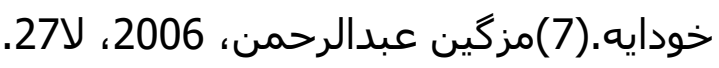

: سيّيهم: وازمى يارسان :

ناوى ئهسلّى ريّبازهكه نه كاكهييه، نه ئههلى همقه، نه عمل كى خودايى، بهلّكو ناوى يارسانه.

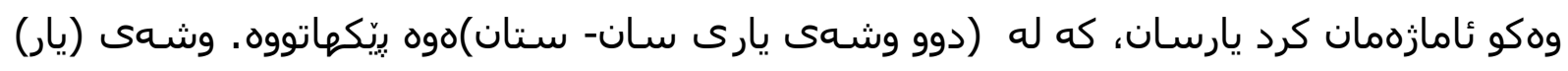

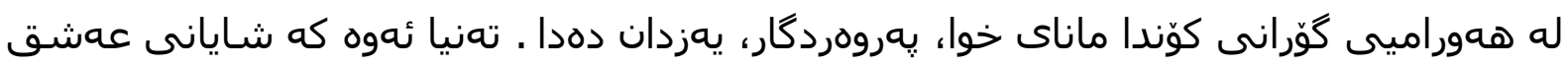

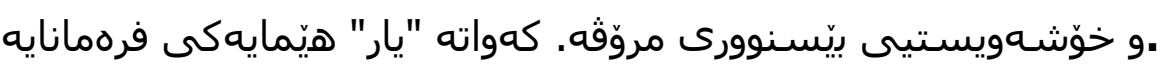

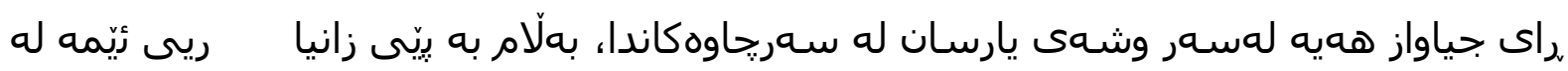

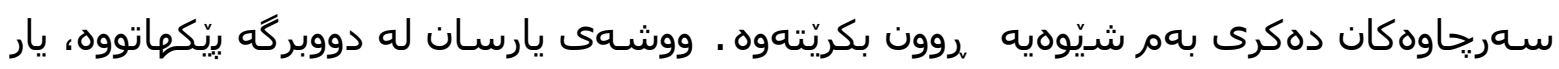

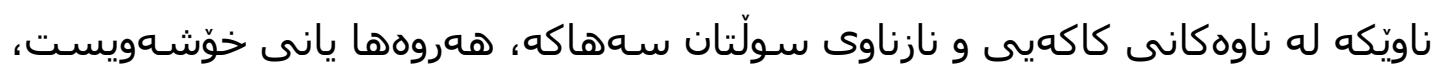

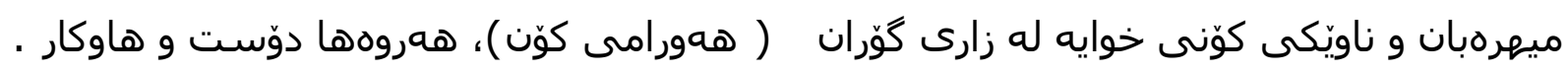

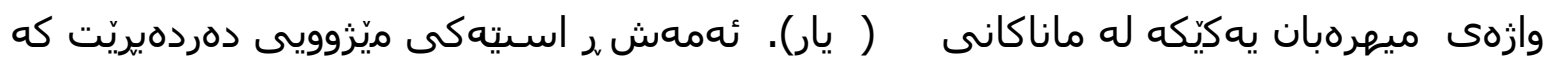

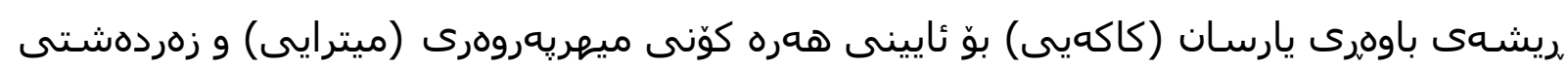

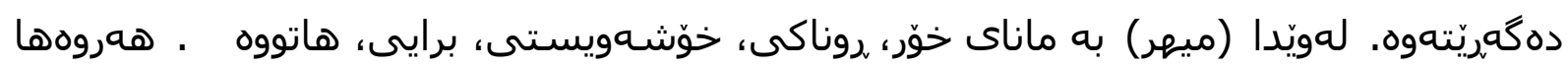

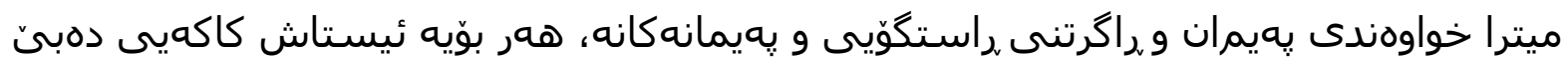

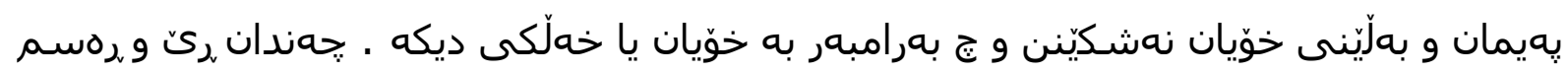

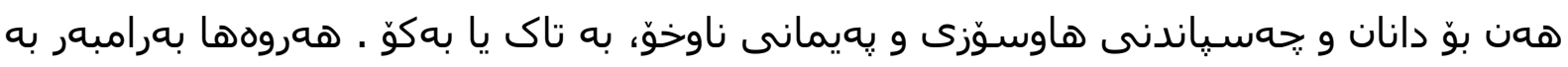

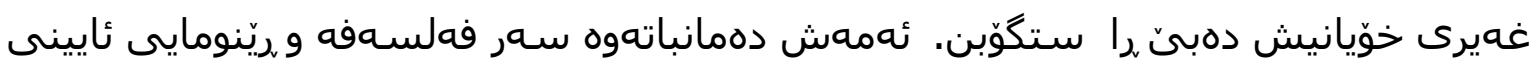

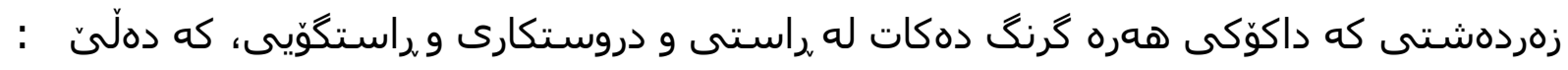
،راستى (ئهشا) ياساى جهوهـرى جيهانه.

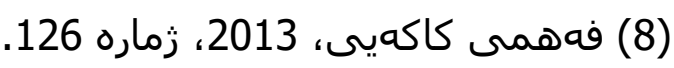

كاكهيى به كتيّبه كانيان دهلِّين دهفتهر ( بهياز). دهشبينين كه بهيازهكانى يارى (واته: يارسانى)

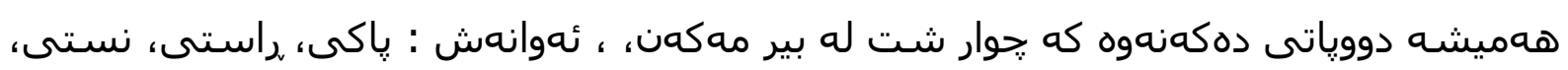

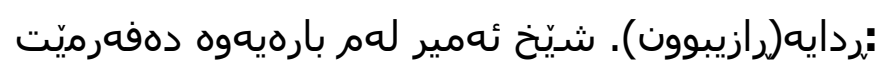


يارى جوار :جيوهن باوهرى وهجا

راستى و پإكى ونيستى ورددا

پاكى له ههموو شتيّكدا : زمان و بير و، ذفتار و جهسته و جل و بهرگ و ههموو زيان .نيستى: واته خاكه رايى، بـن فيزى (تواضع). ردا. واته: رازيبوون(قهناعهتكردن) جواميّرى و ميهرهبانى و و

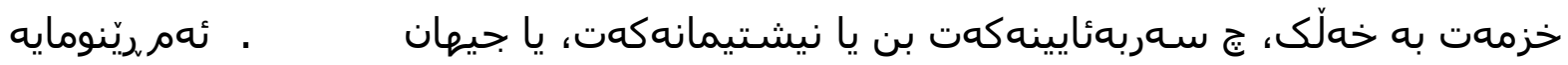

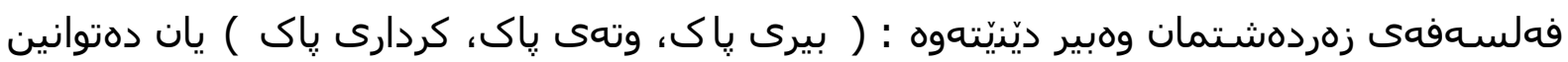

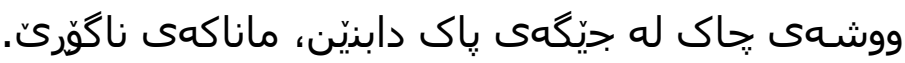

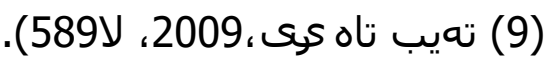

(سان) بركَى دووهمى(يارسانه) كه ماناى: سولّتان، مهزن، يِيروّز، و مهلّبهنده به نويّكهرهوهى ئايينى يارسان، يارانى سـولّان ئيسحاق، كه بهر له ههفت سـد سـالّ دهركهوتووه دهلِّين

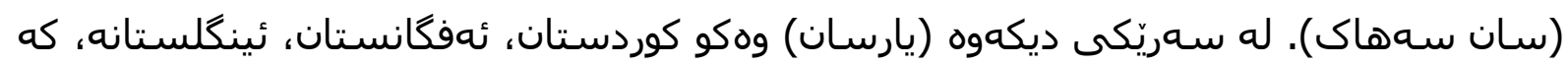

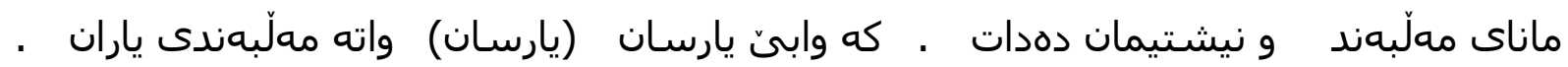

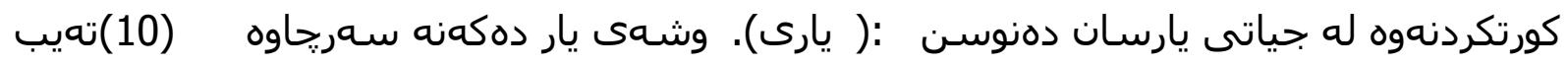
تاهيرى، لأباه.

ليّكدانهوهيهكى تر ههيه كه به راى ئيمه له راستيهوه نزيكتره ئهويش بهو بهلّكهيهى كه وشـى

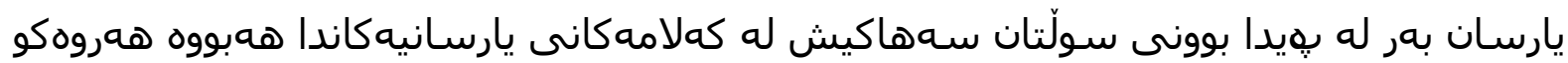

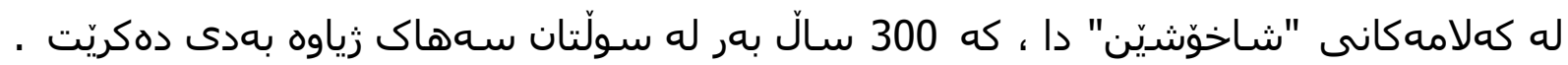

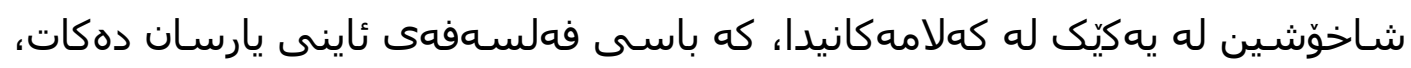

:دمفهرمويت:

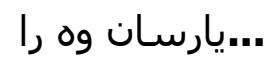

راى حهق ،راسييهن، يرانان وه ،را

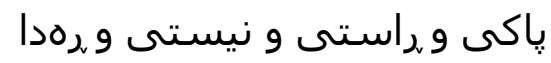

قهدمر وهقدهم، تا وه مهنزلّا

،روون و دياره ئهمروّش وشهى يارسـان ناسـامهيهى كورديى يهتيتر به ئايينهكه دهدات، ناويّكى

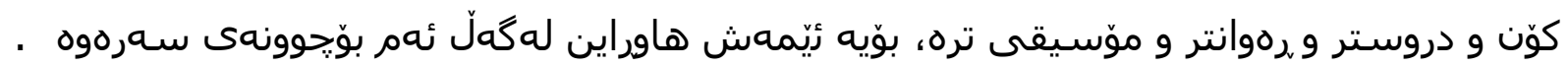

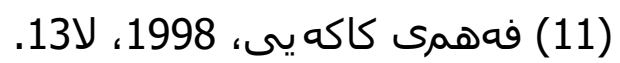

ئايينى يارسان.

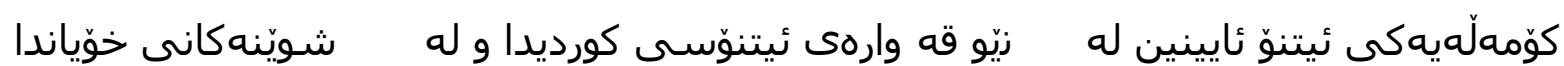

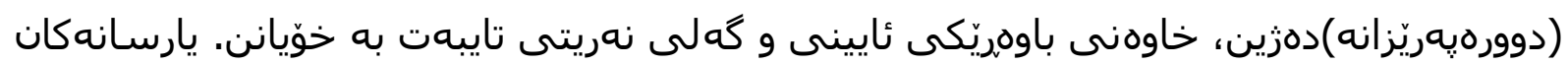

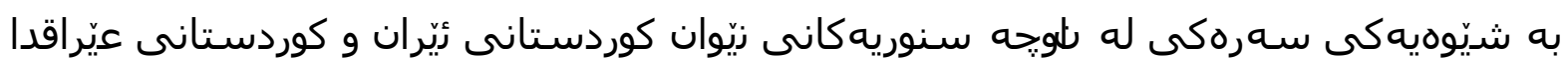

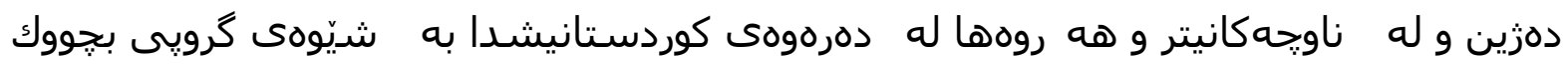


دذزين، تا ئيستا هيجِ مه تريالّ و سه ريجاوهيهك سه بارهت به زمارهى يارسانه كان له ئارادا نييه.

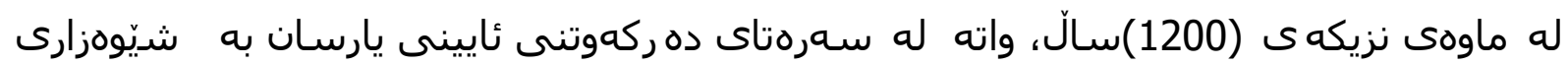

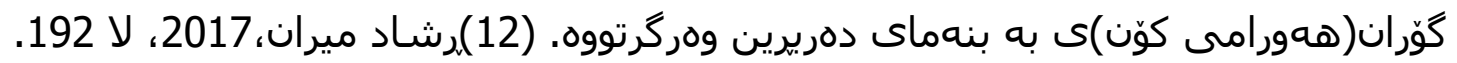

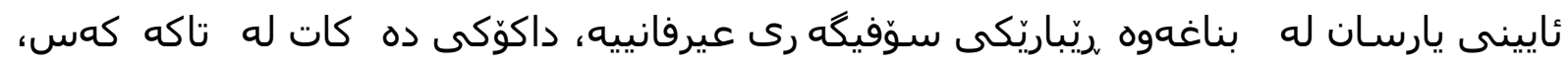

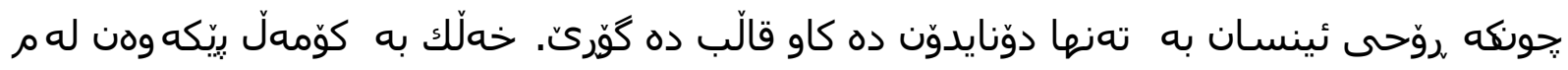

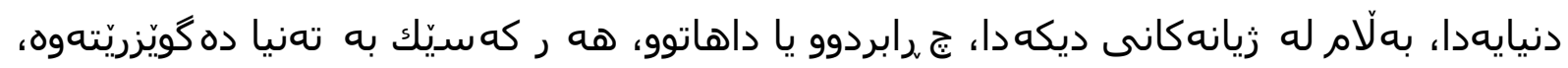

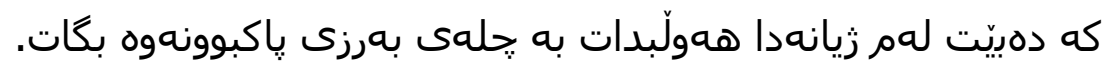

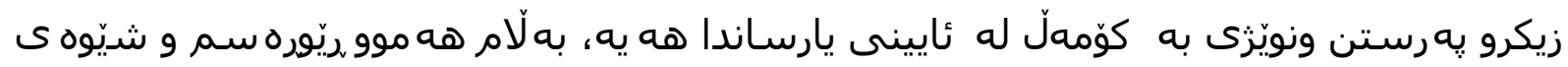

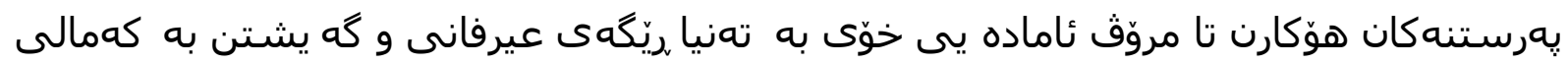

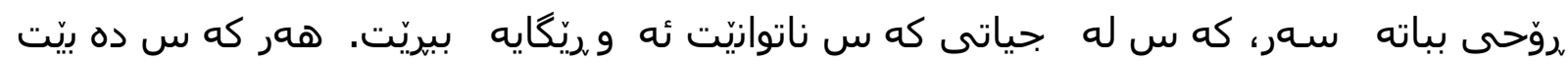

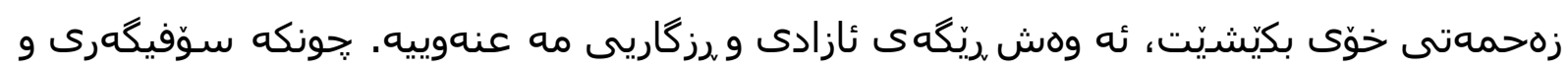

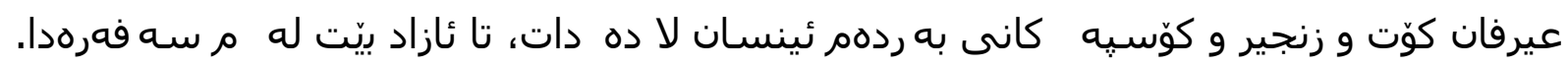

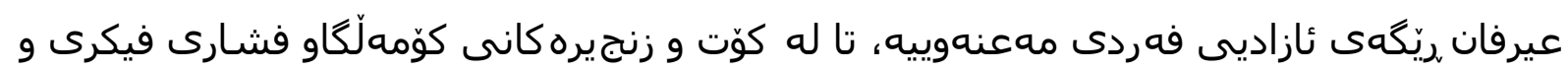
دابونهريت و وههمهكان درزخارى دهريت.

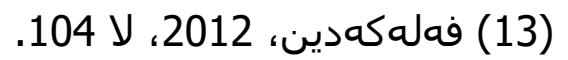

سوّفيكهرى و عيرفانى يارسان، له جهوههردا، هه مان ريّكَى سوّفى و عارفانى ئايينه كانى ديكهيه. ههربوّيه يارسـان سـوفى و عارفه كَوره ناودارهكانى جههانى ئيسلام بههى خوّيان

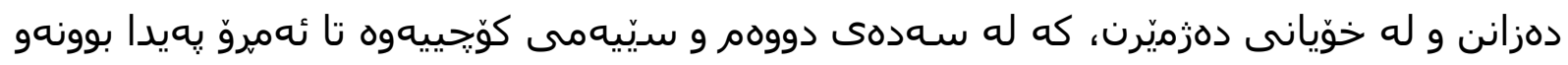

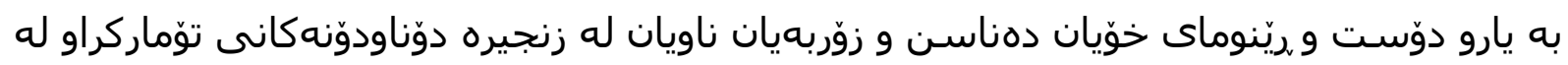
زيكسته بِيروّزكانييشياندا، ناويان هاتووه.

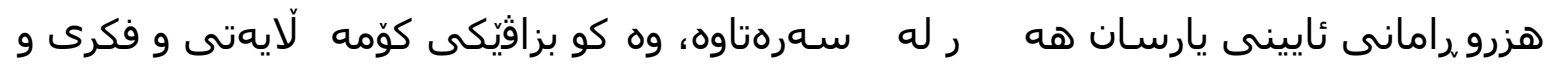

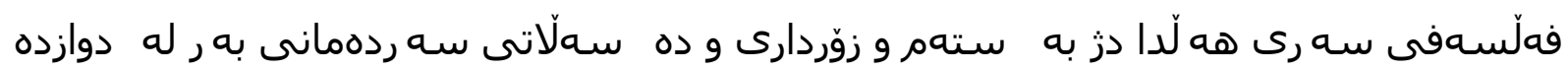

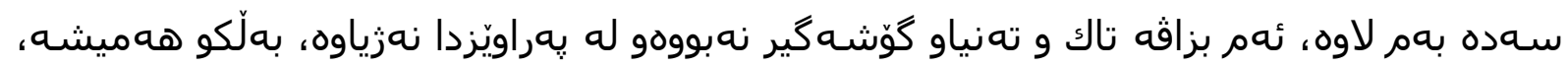

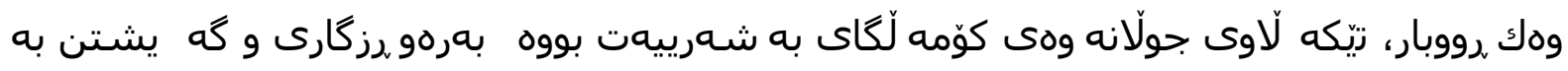

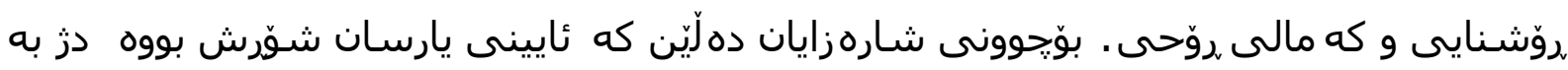

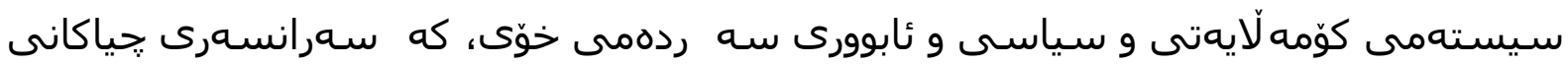

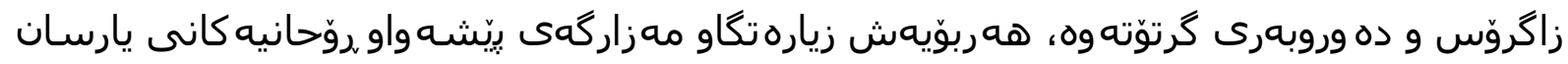

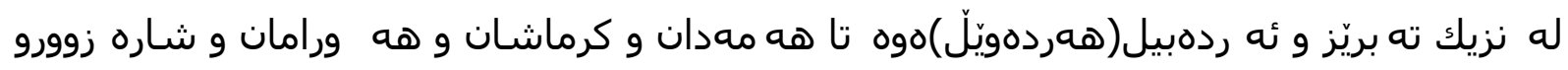

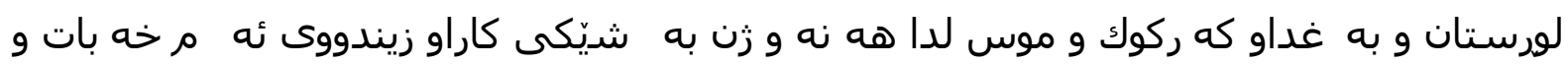

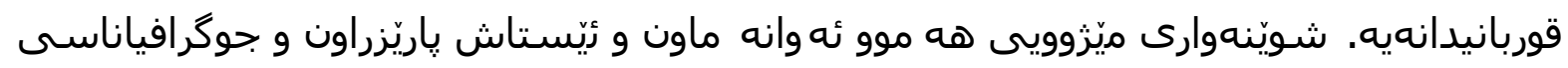

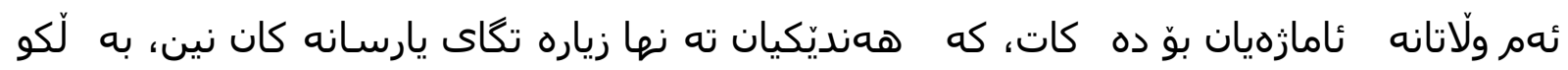
باوهردارانى ئايين و ئايينزاكانى ديكهى دهوروبهريش ياديان دهكهنهوه و زيارهتيان دهكهن. 


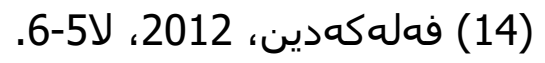

جيّكهو نشيمهنى يارسانيهكان

يارسانيهكان ئارى نه زادن، سـه به لقى هيند و ئه ورويين و له زممهزيكى نادياردا، واته زجهند

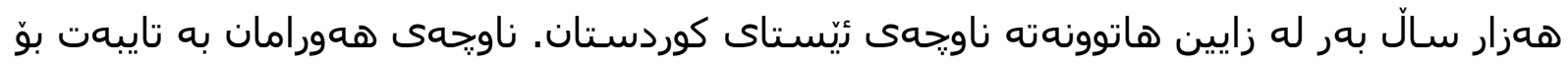

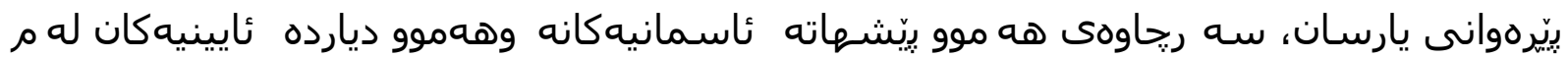
سهرزهمينهدا دهردهكهوكّ. شويّنهكانى نيشتهجنى بوونى يارسان له كوردستاندا، له كوّنهوه تا

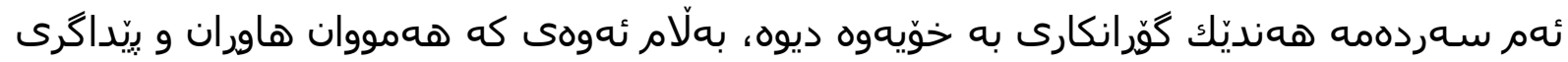
لهسهر دهكن ئهوهيه، كه له سهرةتادا ئايينى يارسان له ناويجهانى هaورامان و شاره زوور و

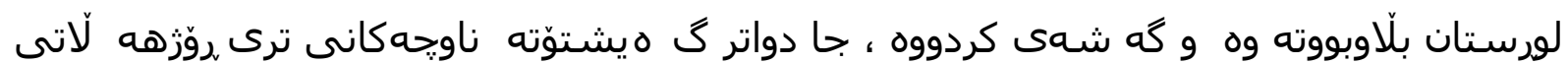
كوردستان. (15) تهيب تاهيرى، 2009، لاهون.

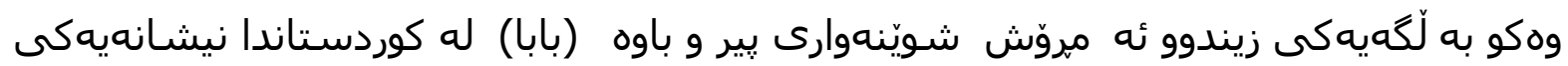
ديكهى ديروّكى ديّرينى ئايينى و نهتهوهيى كورده كه هيّشتا وهكو بِينويست كارى لهسهر نهكراوه. (بابا) له فهرههنگى كورديدا وهى و ييرى ييرانه و خاوهن وهجاخ (ئوجاخ) ى تايبهته.

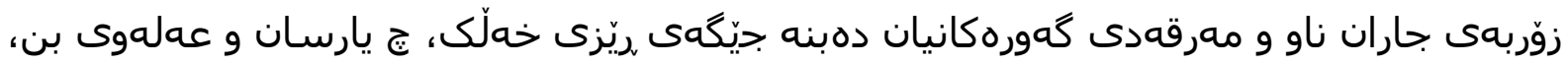
يا له مهزههب و ئايينى تر بن . ههر له لورستانهوه جيَّا و نشيمهنى باباكان تهماشا بكهين، تا ههورامان و كهركوك و ئازربايجان و دهرسيم، دهيان زيارهتكا و شـيّنهواريان دهبينين، وهكو : بابا ناووس، بابا يادگار، بابا تاهيرى هممه دانى، بابا جهليل و يارانى، بابا شاسوار (كفرى) بابا

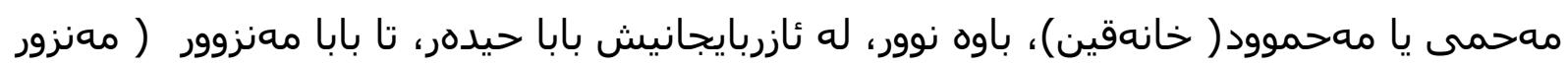
با با و مهنسور بابا و بهبهكانى دهرسيم و ناويحهانى ديكهى باكوورى كوردستان، كه به

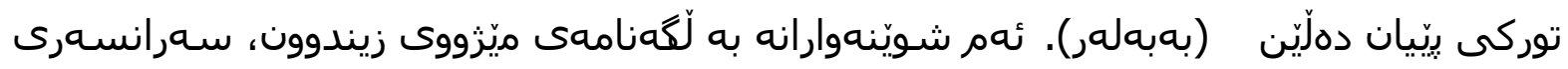

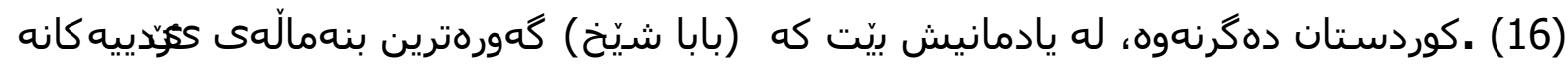

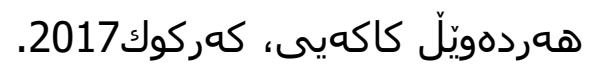

:حوّنيهتى دامهزراندنى ئايينى يارسان:

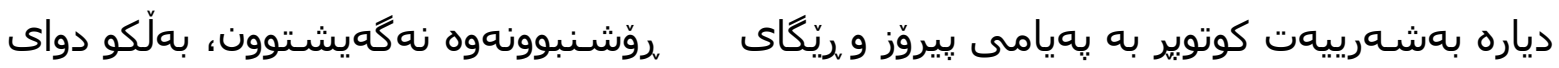

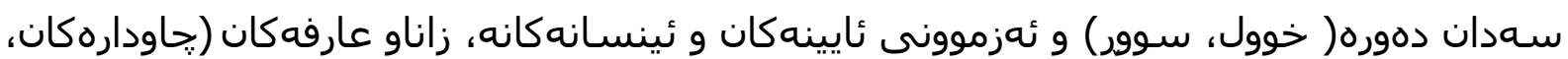

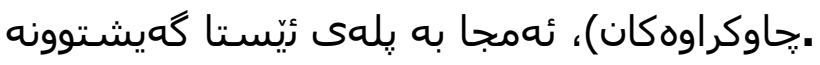

دياره له دهورهكانى يهى بهدوواييهكى هاتن و ئاشكرابوونى نايينى يارسانيش حيكمهت ههيه،

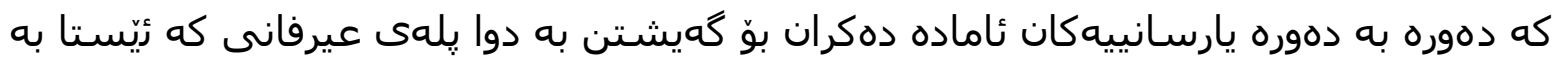

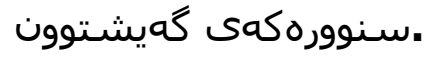

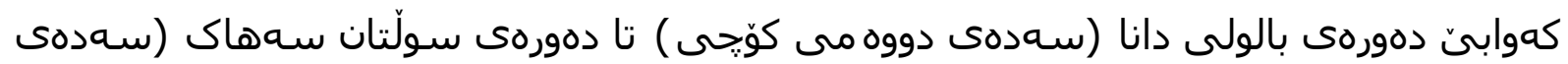
ههشتهمى كوّحى)و ئهمجا سهيد براكه و له زيّوانياندا دهيان دهو رهو دهركهوتنى ج اودار و زاناى 
ردوشـندل، لهبهر ئهوه بووه كه خهلّك له سهرهمى بالوولدا (سهدهى دووه مى كوّحى )ئاماده

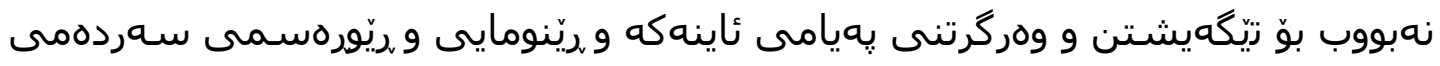

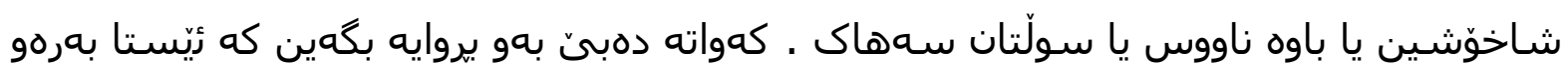

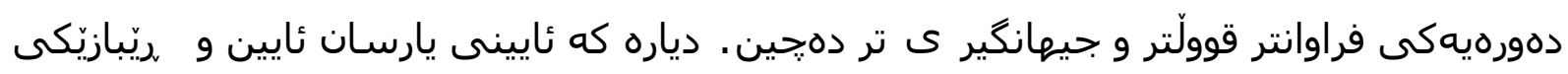

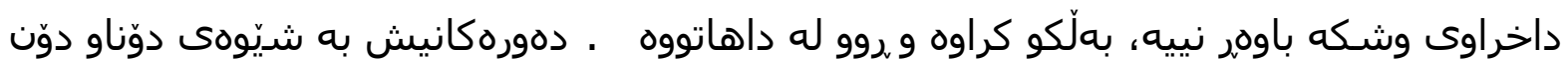

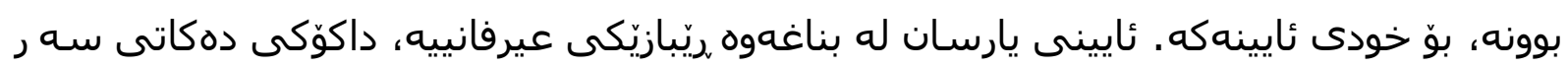

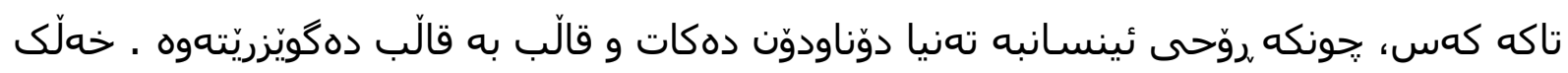

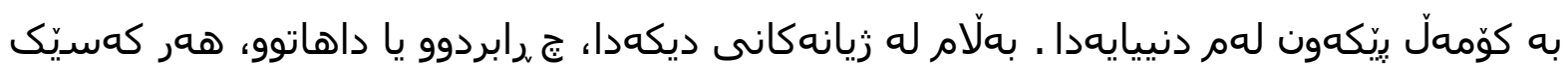

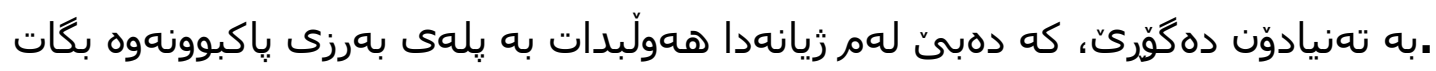

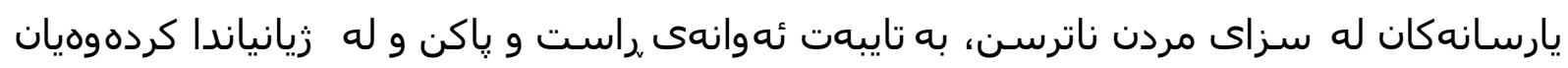
باش بووه. له سـرهنجامدا هاتووه:

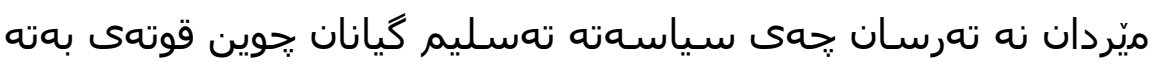

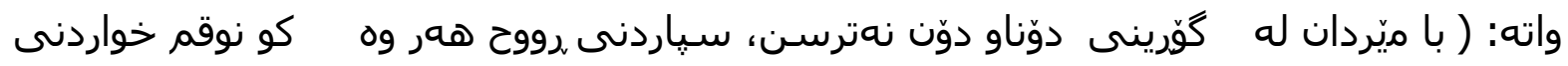

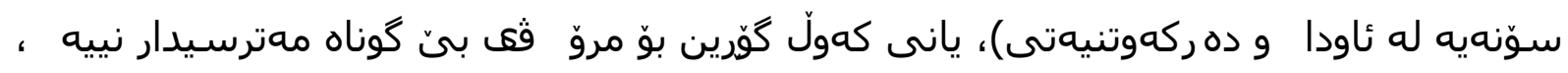

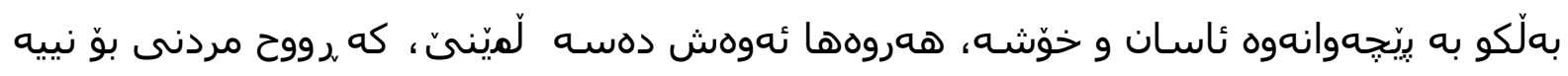

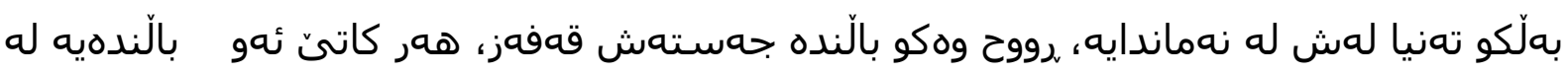

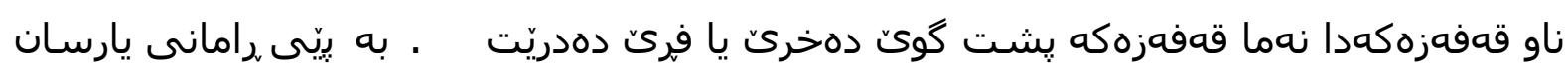

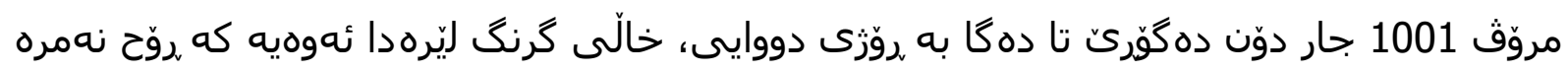

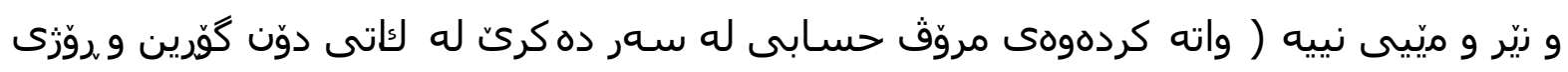

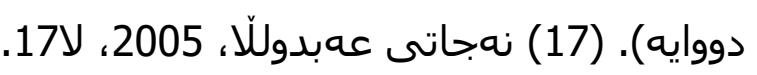

دوّكماكانى ئايينى (يارسان):

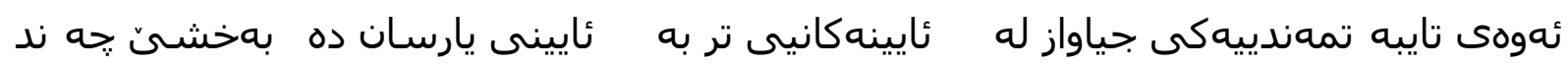

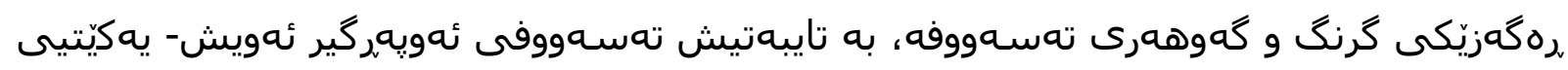
بوون (وهحده الوجود) و تجسيدى ئيلاهى (الحلول) و دوّناو دوّنه.

يهكيتيى بوون هه ميشه بهناوى شيّخى گهورهى ئهندهلوسى ابن العربى (1165- 1240) ييهوه

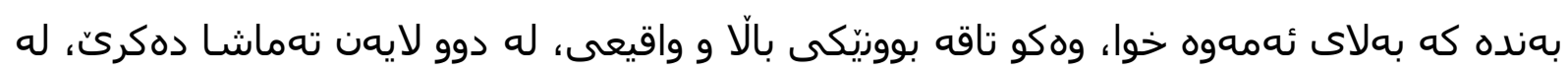

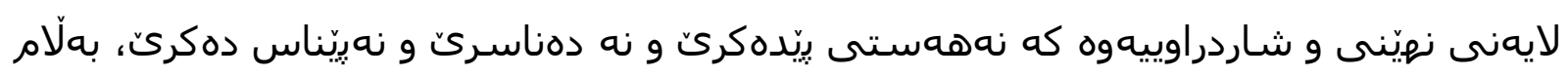

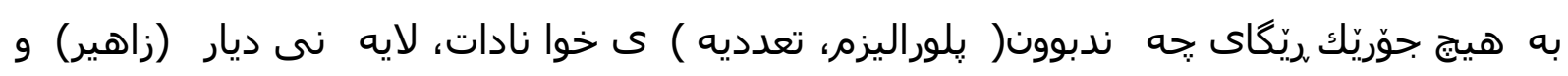

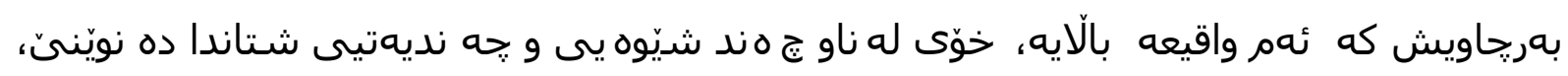

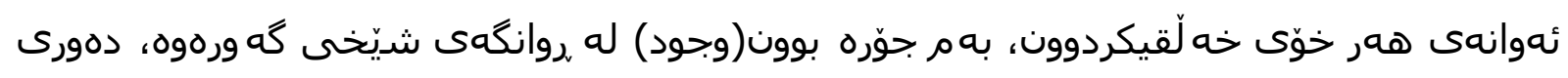

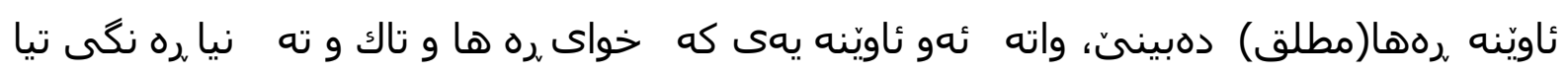


دهداتهوه. بوّ زيّتر دووونكردنهوهى هزرى يه كيّتى بوون ئه م ديّره شـيعرانهى ميرزا غاليب(1797 -

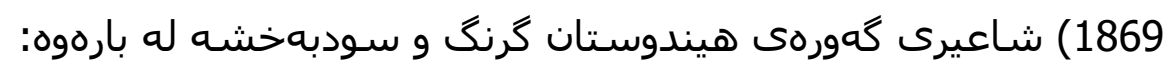

دونيا زجييه؟ ئاوينهى حهقيقهته،

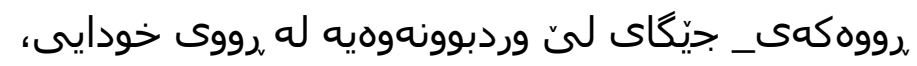

له همره بجنووكترين ياريحهيدا

دهبنى بهِّاوى خوّت نيشانهى تاقه خاليق.

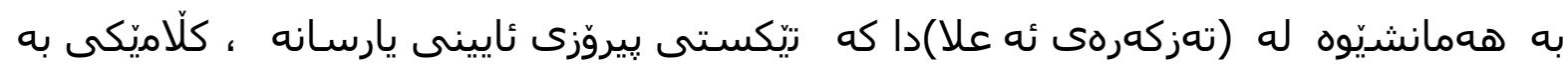

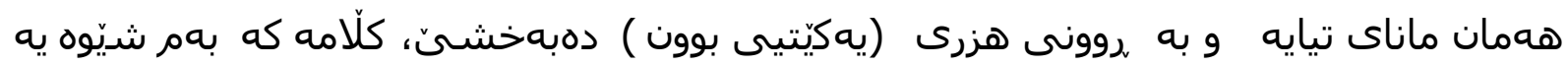

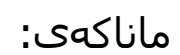

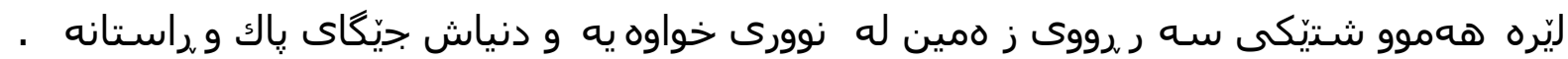

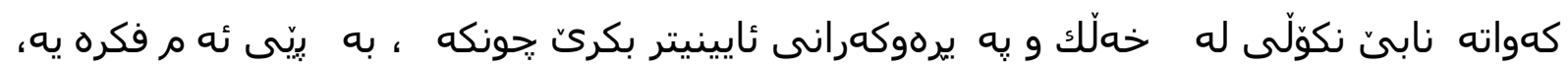

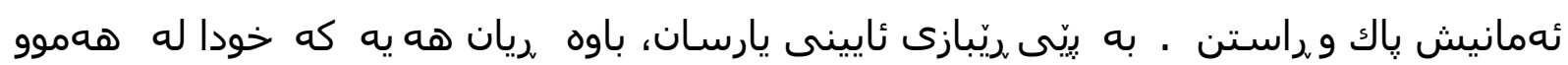

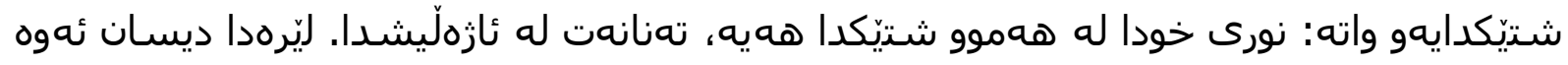

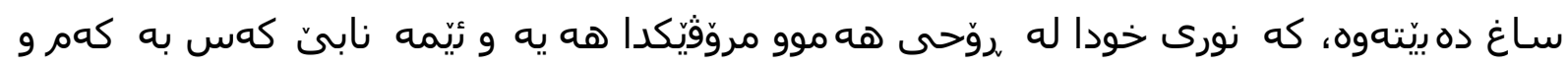

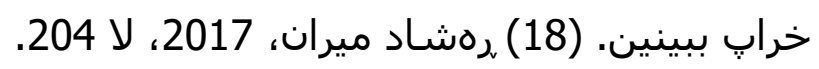

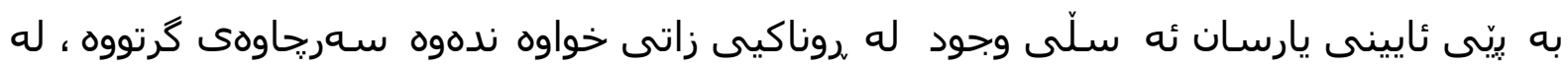

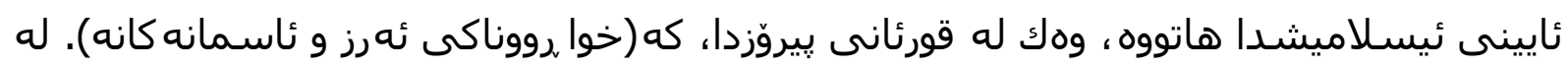

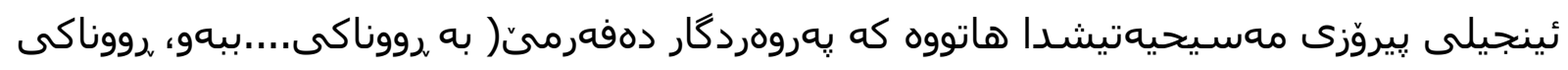
بوو). واته: يهكهم روووناكيه كهى خولّقاند. له كتيّبى ييروّزى (سابيئه مهنداييهكاندا) هاتووه كه

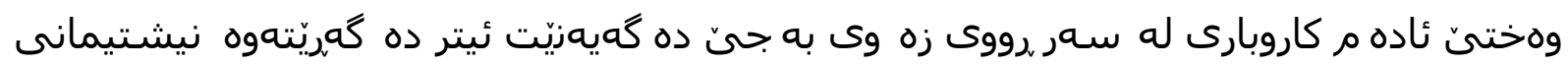

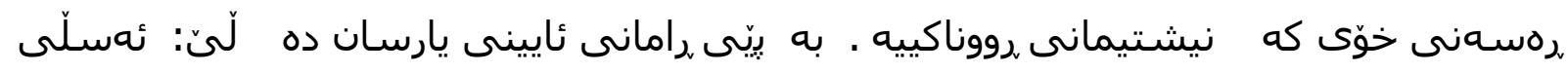

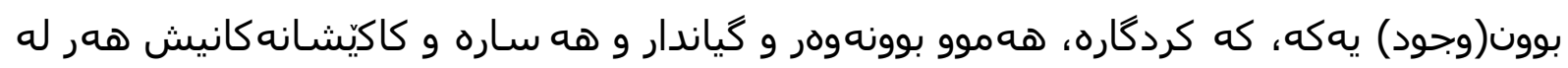
وجودى ئهوهوه يهيدا بوونه، ههموو بِينكهوه بوّ يهك مهرام دهروّن.

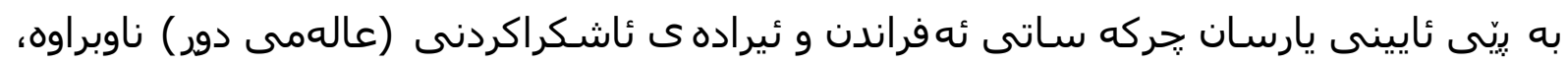
كه خوّى ئوستوورهى ئهفراندنه، له ئايينى يارستان، كه دهكاته يحركهـاتى(كن فيكون)، كه له له

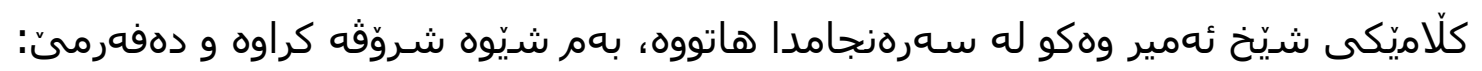

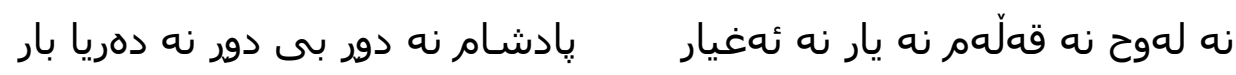

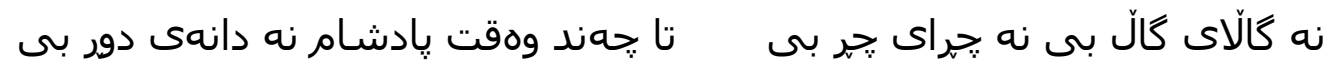

وه له كلّاميّكى تردا يِير بنيامين له سهرونجامدا دهفهرميَت

خواجام الله بى دامم دا نيشا

دامم دا نيشا.....

دورمان راما خواجام بيش كيشا

نه بهحر دورى شيطم ئهو ييشا 


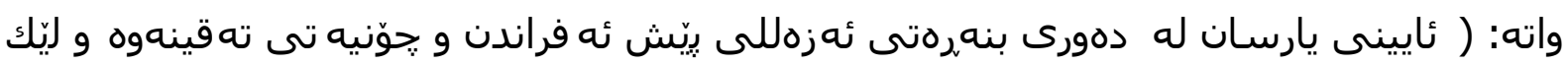

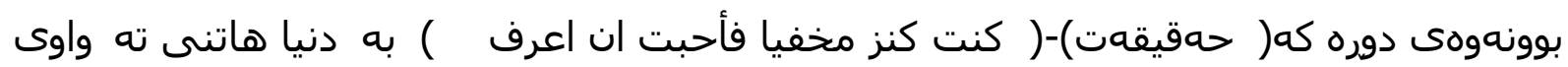

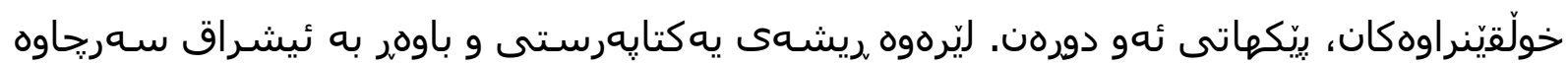

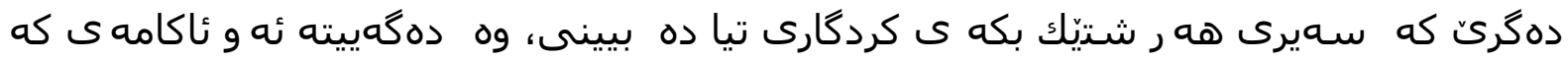
ههبوون و نهبوون حهققهو بهشيّك له زاتى ئيلاهى له جهوههرييدا يهنهان و نهينيه (شاراوهيه). (19) تهيب تاهيرى، 2009، لا 676.

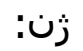

ههر كاتيّك باسـى فهيلهسـوف و عارف (خوّناسـين و خواناسـين)دذكهين، بهبى ئاكًا، مهبهستمان

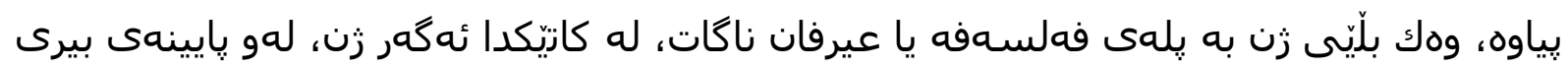

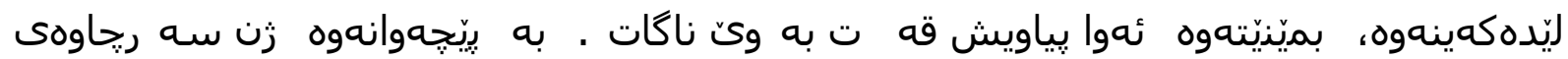

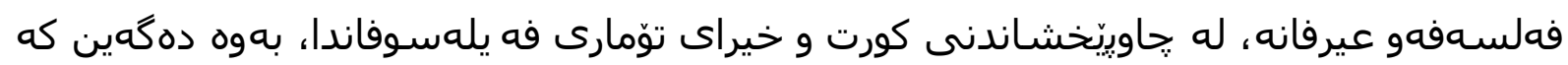

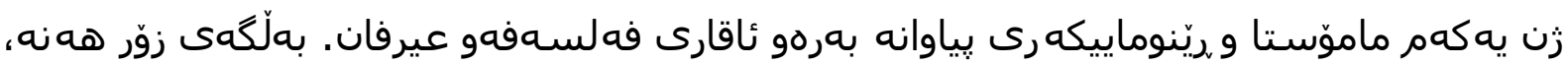

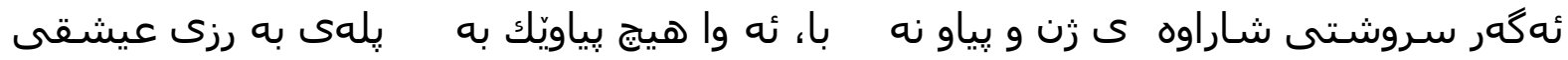
فهلسهفهو عيرفان نه دهكهيشت. له زيان و ئه زموونى هه رعاشقيّكى مه زن زن هه يه، ج ديار

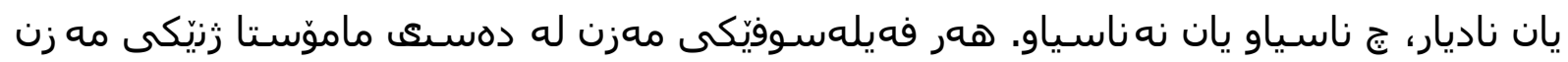

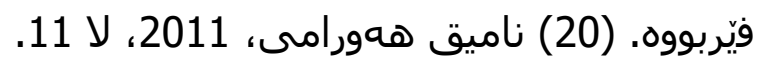

ئافرهت له ئايينى يارسان بِينكهى خوّى ههيه. بوّى ههيه، وهو بياو، به بهرزترين يلهى كهمالى

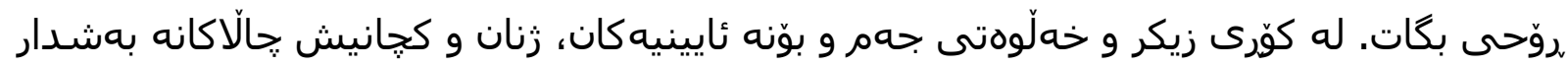
دهبن و موزيك دهزهنن و سـرود دهخويّننو خزمهت دهكهن. له دهورهكانى دهركهوتنى خواناسى و و

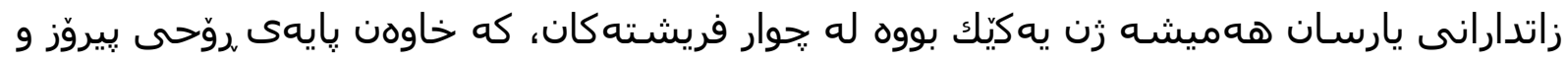

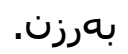

له تيّكستهكانى سهرهنجامدا ناوى زياتر له(16) زن و كج له ناو روّحانى و گهوره ياراندا هاتووه، كه ههنديكيان تهميره زهن(موزيك زهن)وخوينهرى به ئاوازى سـرود(كلام) ركانى يارسان بوونه و و

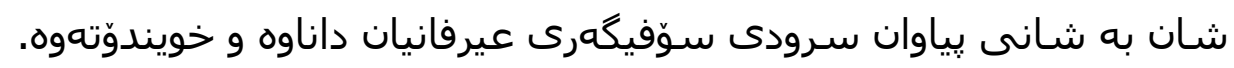

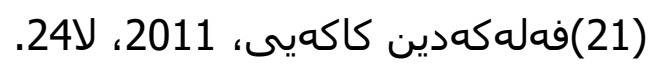

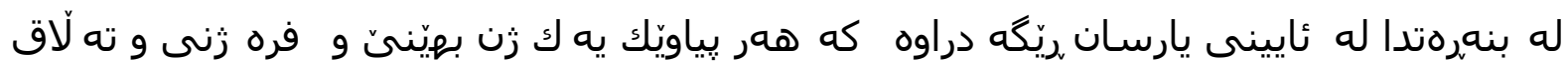

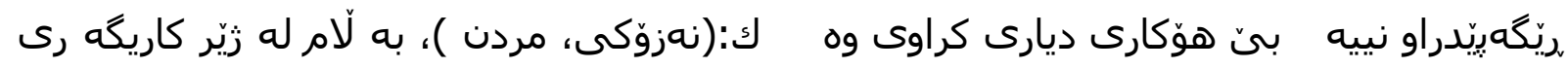

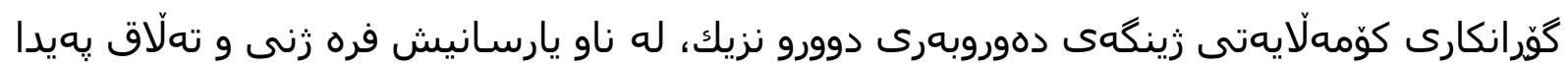

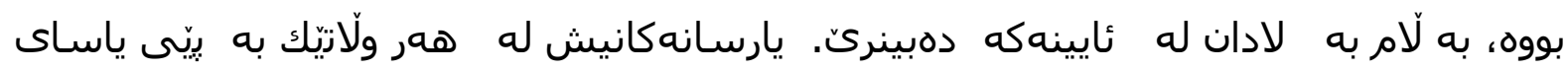

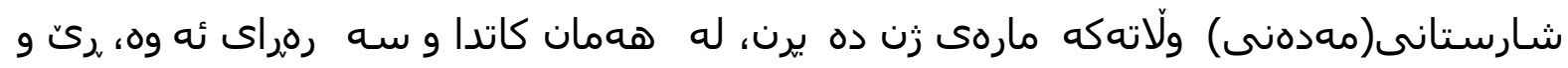

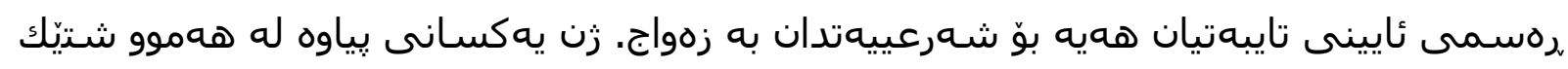


به ميراتهوه، هه روهها مافى زنان و كِانه لهسهر خيّزانه كانيان تا فيّرى زانست و ئايين بكريّن،

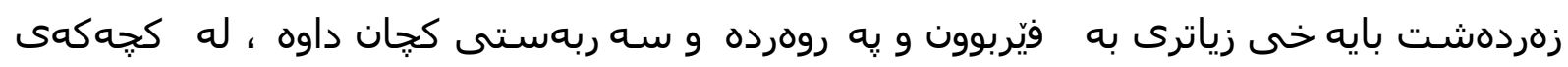

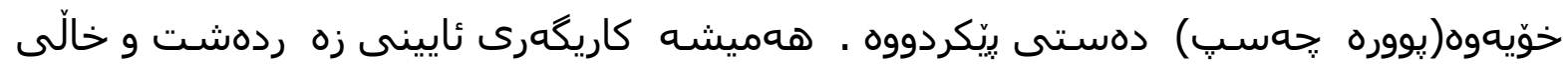

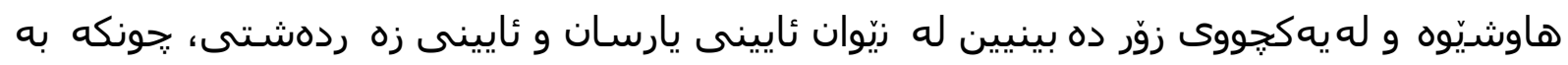

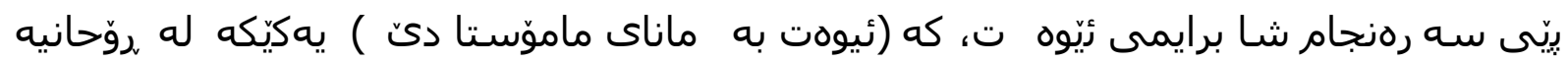

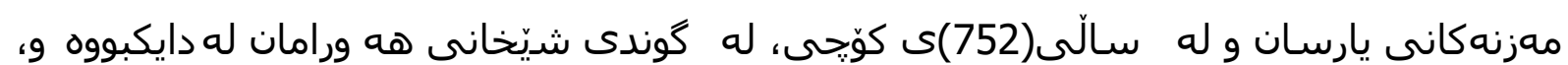

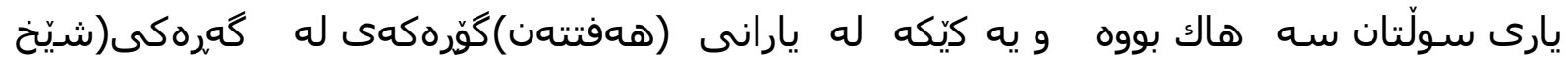

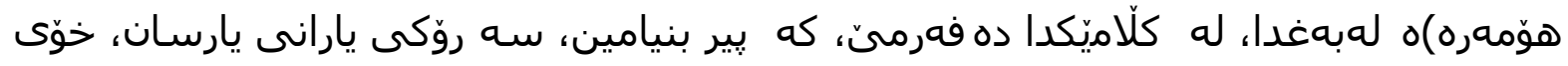

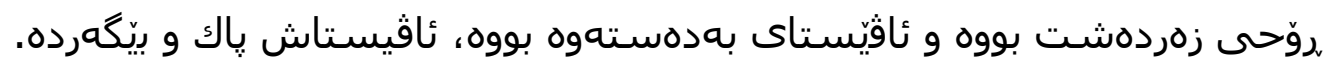

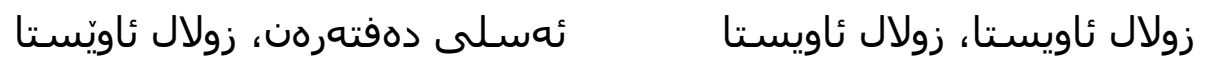

بنيام زهردهشتهن، دهفتهر وهدهستا زاتش جه بادهى شاهونشا مهستا

كه ليّره مهبهست له وشـى (شاههنشا)، كردگاره(خويّيه). (22)جهمال نهبهز: 2009، لا 27.

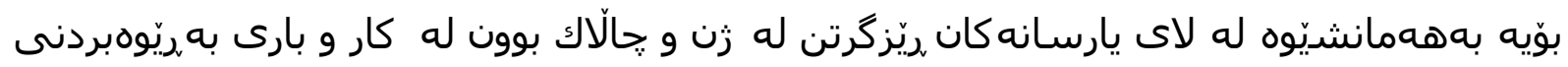

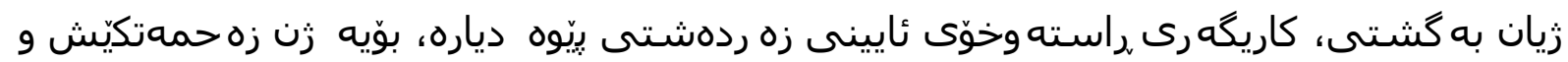

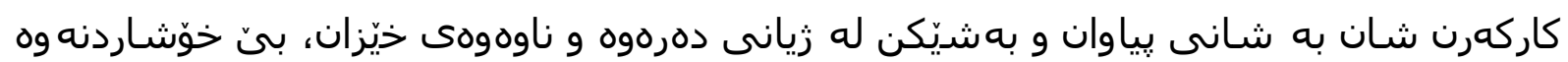

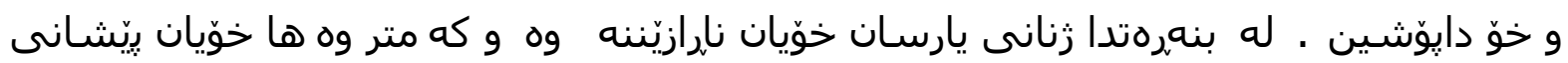

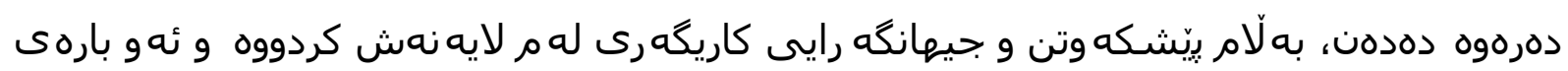

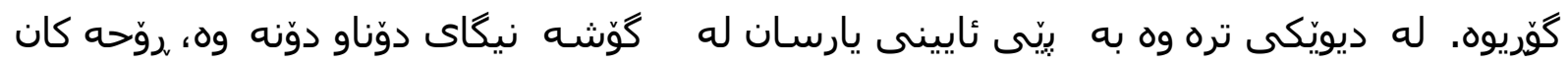

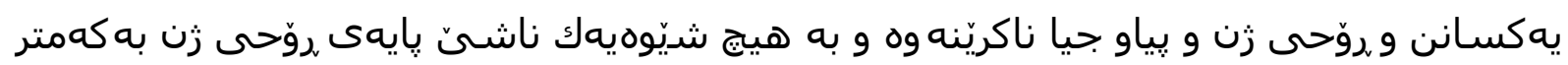

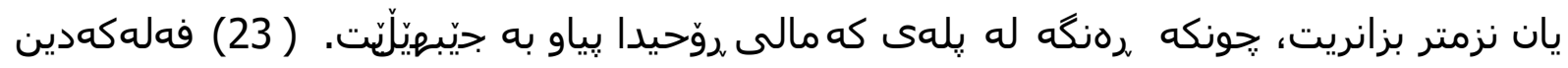
كاكويى، 2011، لا 25.

له ،ريشهدا ئاوهدانى و شـارستانى و فهرههنگ و هزر له ههر شـويّن و ناوِحهو ولّاتيكدا، تهنيا به

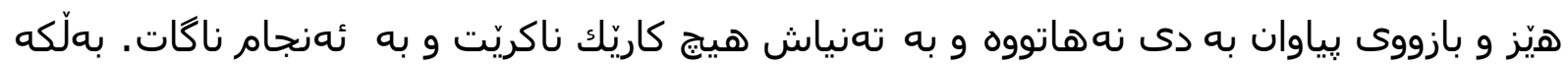

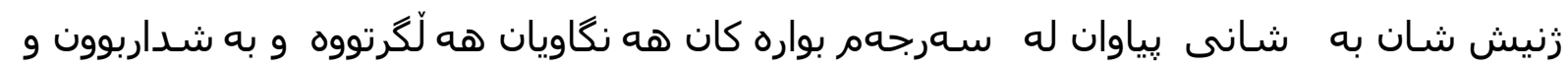

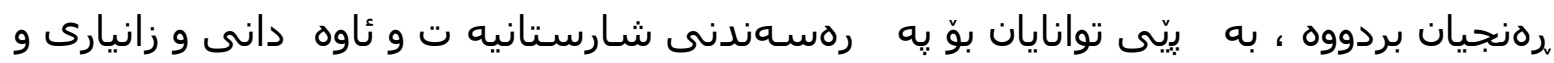

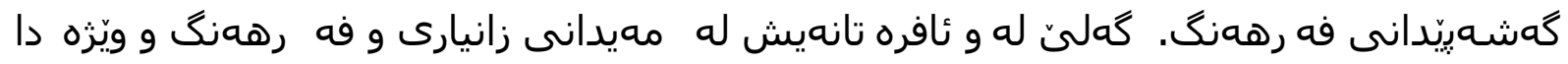

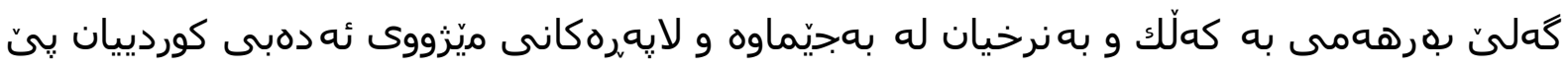
،رازاندووهتهوه. (24) همياس، هموليّر، 2017.

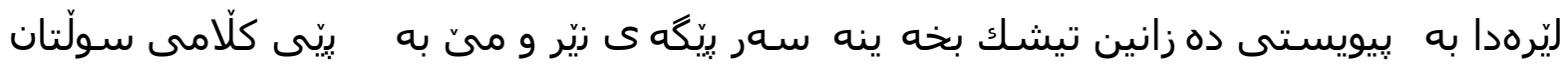

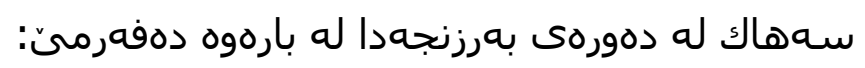

تهوفيرشان نييهن كناجهو كورى باهذره

كناجهو كورى 
بهش باتنهن ئهزهل هموهرى خاتوون دايهراك ئى بهشش خرى

يوّشاك يارى ئهو بالاش يرى

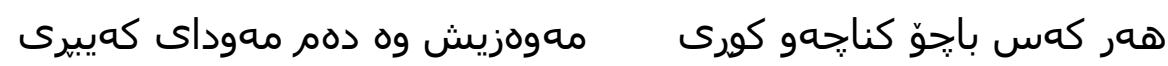

واته: (نابن به هيج شيّوهيهك جياوازى بكريّت له زيّوانى كور و كجدا، :جونكه له ديينى يارساندا

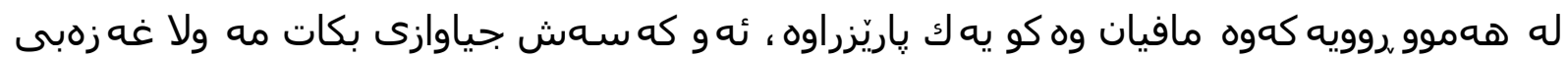

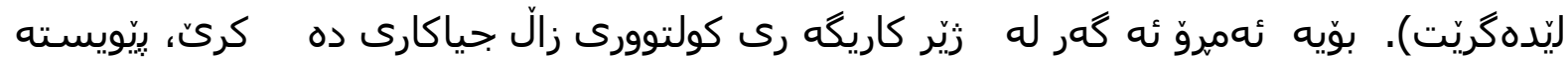

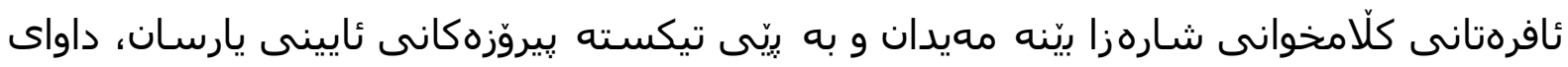

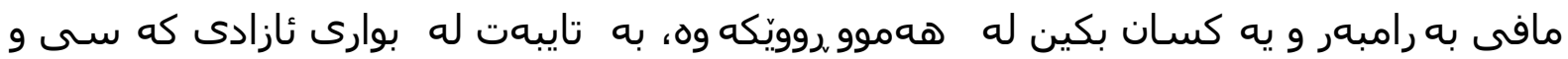
ميرات و مافه ياساييهكان.

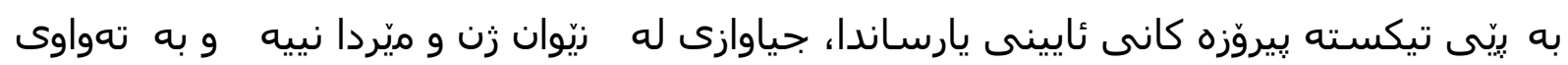

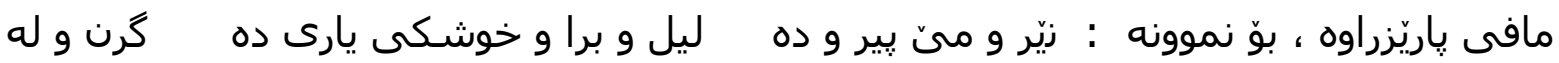

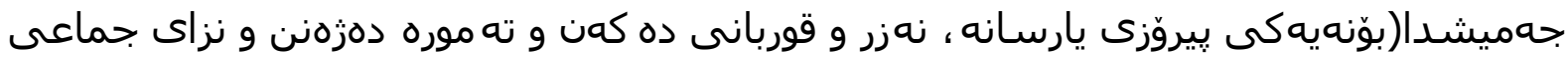

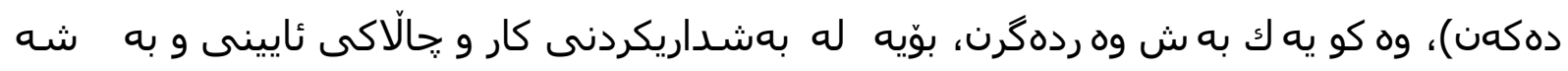

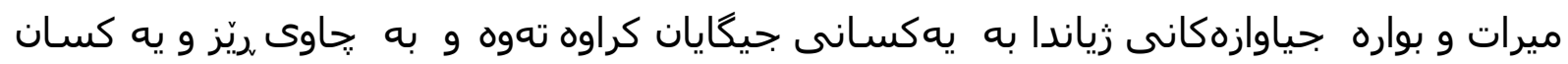

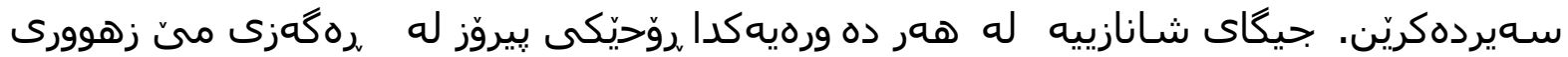
كردووه و ئافرهزيكك يا زياتر بهشـار بووه و دهورى گرنگ و كاريگهُريان بينيووه له بواره شـيعر و ويّزه

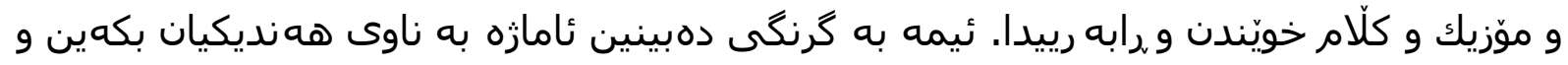

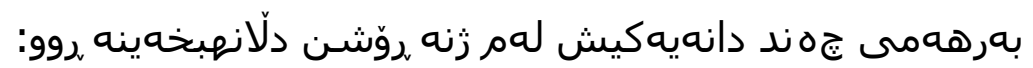

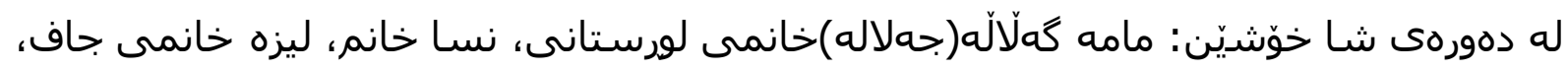

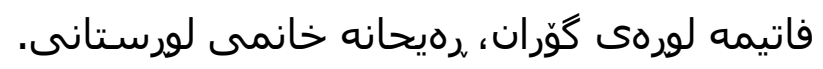

له دمورمى بابا جحليل: سممهن خانم

له دهورهى بابا ناوس: خاتوونه گُلّى و دادا يان دايیى خهزانى سهرگهتى.

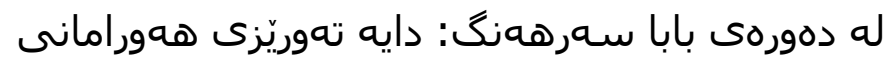

له دهورهى كاكه عابهدين: شـمينه و نهرگزه خانم

له دهورهى يرديّوهريشـا: دايه رهزبارى گهوره(دايراك)، دايكى سـولّان سههاكه.

له دهورهى شا ئيبراهيم : خاتو زهينهب.

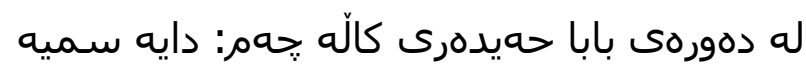

له دهورهى سـييد فهرزى خاموّشى : زهرين خانم.

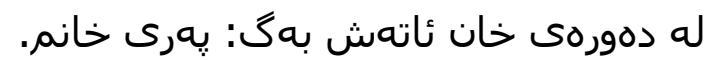

له دهورهى شا همياس: زهربانوّ خانم.

له دهورoى زهنوور: ئهسمهر خاتوون. 


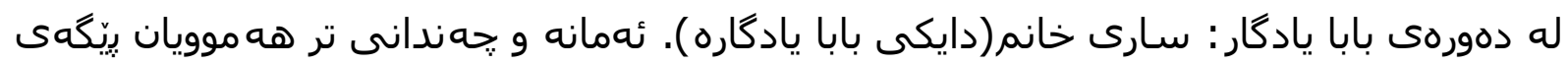
مهعنهوى بهرزيان ههيه له ئاينى يارسان و له ريّزى ميّردان حسابكراون و خزمه تيان كردووه له

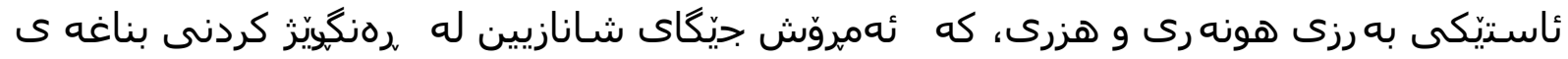
كولتوورى كوردا. (25) ههردهويّل كاكهيى ، 2016.

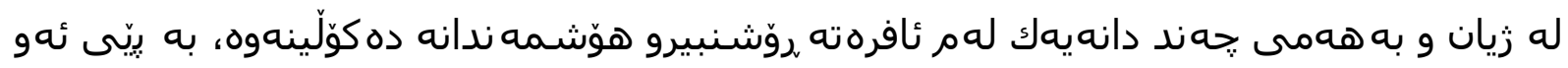
تيّكستانهى له بهردهستدان و به سود وه ركرتن له جهند سه رياوهيهكى سه رهكى تر، كه لويتين له كتيّب و ده ستنووس و كلامه كانى يارسان و سه رهنجام و زانيارى يِيره كانى يارسان،

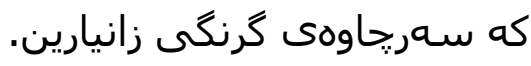

1 1. د دايه تهوريّى هaورامى

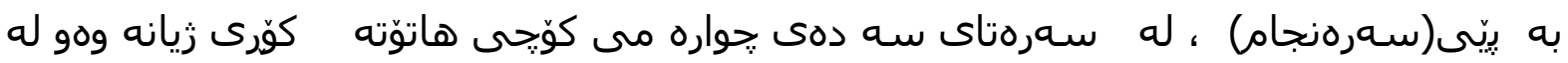

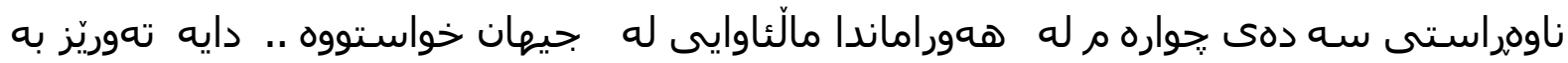
يهكى له يارانى بابه سهرههنگى دهودانى دهزميردرك، ئهم ئافرهته يهكهمين ئافرهت بووه كه

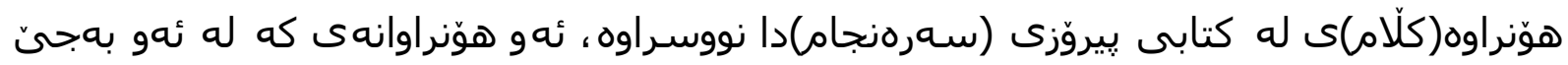

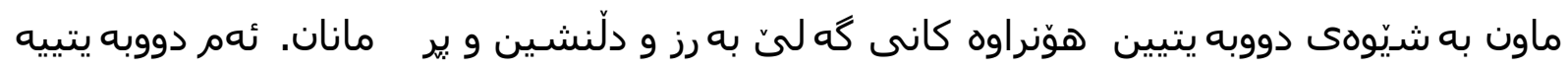
نموونهيهكه له هوّنراوهكانى:

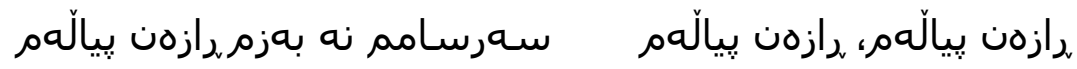

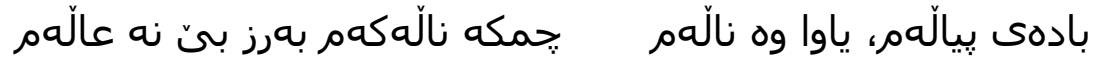

(26)تهيب تاهيرى، سهرهنجام، 2007.

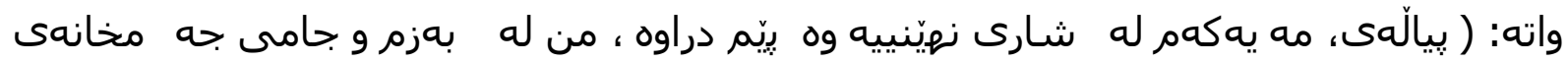

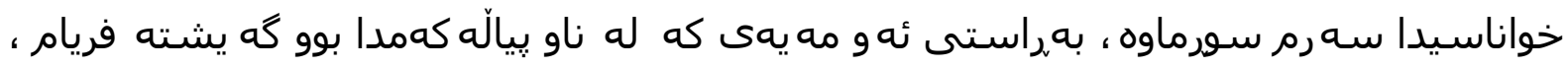

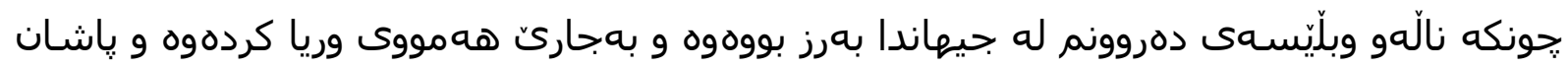
به هوّى خواردنهوهى ئهو مهيه ئيلاهيه كهميك ئههوهن بوومهوه.

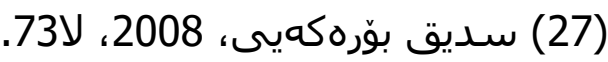

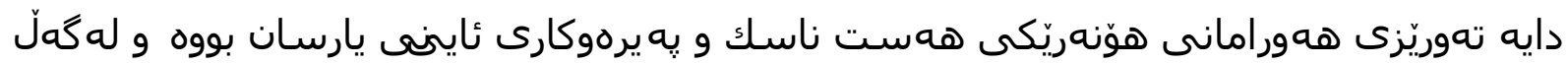

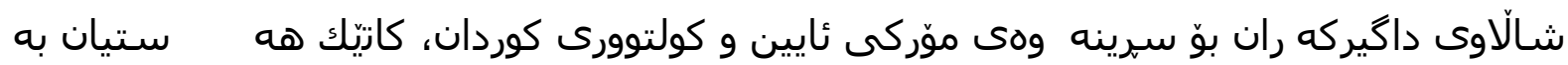

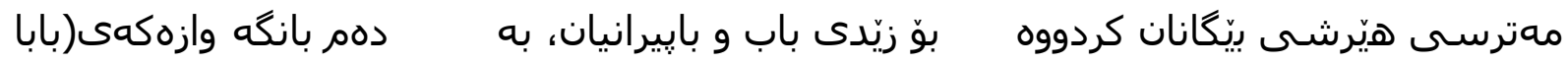

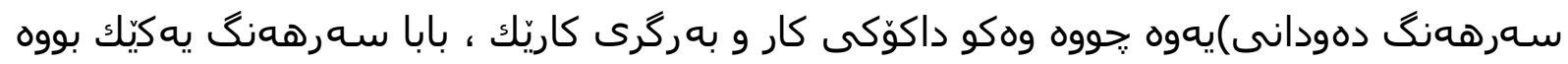
له بِيرهوانى ئايينى ديّرينى كوردان و لهو بِيناوهدا كيانى به خشيوه و زيّيستا ئارامكاكه ى له

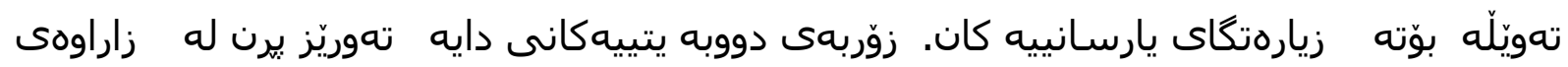
خواناسى. ئهم زاراوانه هور له كوّنهوه، هوّنه رانى(شاعيرانى)كورد وفارس له هوّنراوهكانياندا

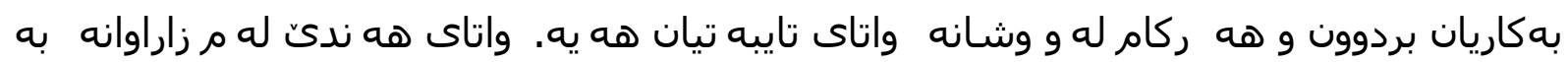


شيّوهيه(راز به واتاى ته ماشاكردن وراز خاوه ن كردنه. بِيالّه: بريتييه له يار و دلّدار، كه بادهى زانيارى و خواناسـ دهخواتهوه. باده: به واتاى كوّمهكى خودايى و ئهوينى بهرز و گُورهيه، نالّه:

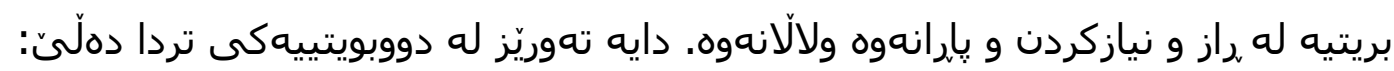

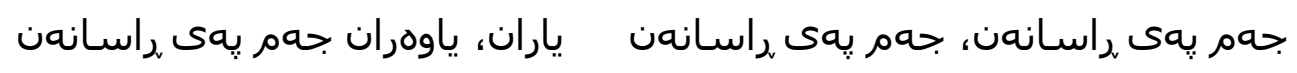

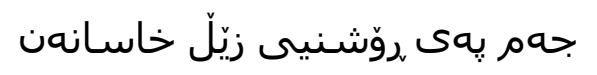

هaر كaس زيّوهكى كaروّ ئاسانهن

(28) تهيب تاهيرى، سهرهنجام، 2007.

واته: (ئهى يارانى يارسان، كوّبوونه وه له جهمخانهدا بوّ راستان و پاكانه . ههر كهسيّك لهويّدا

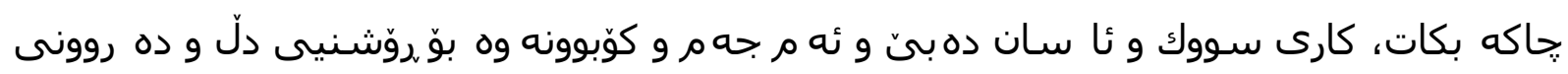

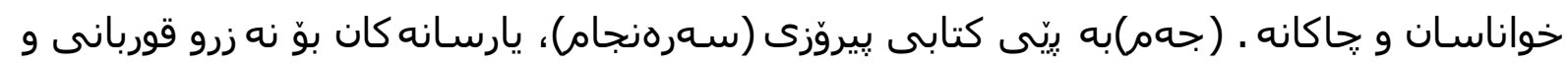

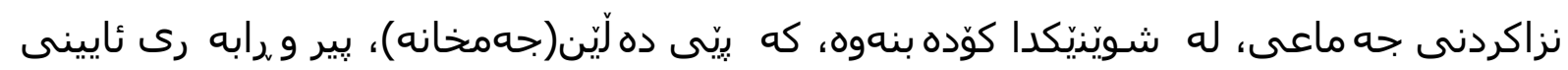

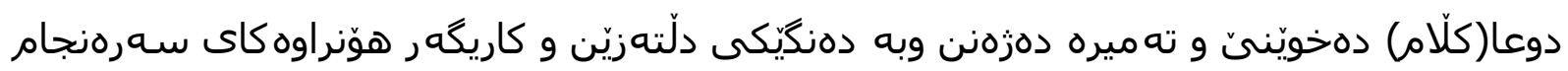

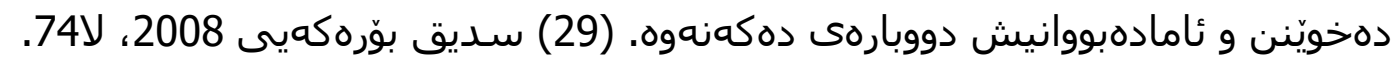

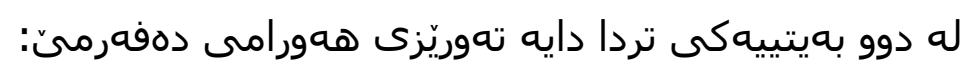

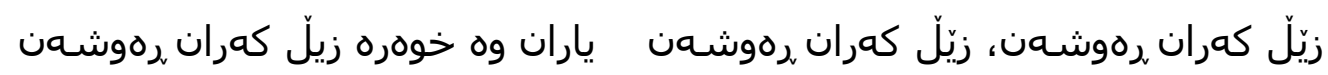

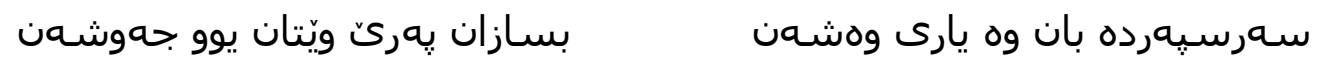

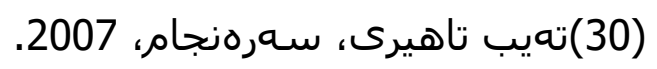

واته: (به رِيّى ،رامان وهزرى ئايينى يارسان به ئاكا وهرنهوه و سـهر به ريّبازى يارسان بسيِيرن و

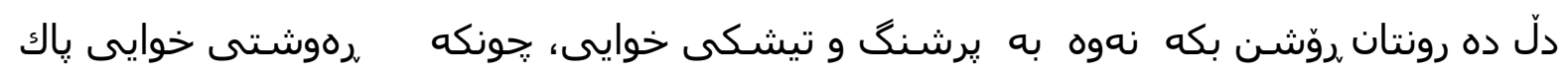
وجوانه). (31)ناميق هوررامى، 2011، 20نو، لا 81.

2. جملاله خانمى لورستانى(387 ى كوّيحى) جهلاله خانمى لورستانى يه كيّكه له ئهستيره كهشه كانى ئاسمانى لورستان و كجى ميرزا

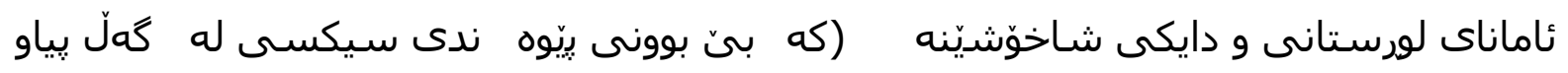

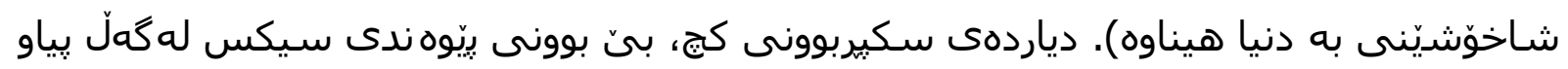

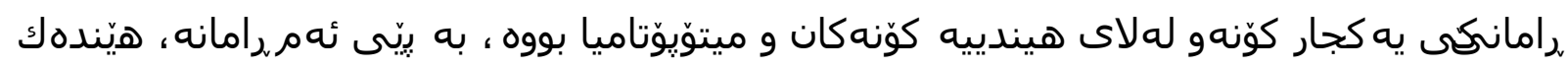

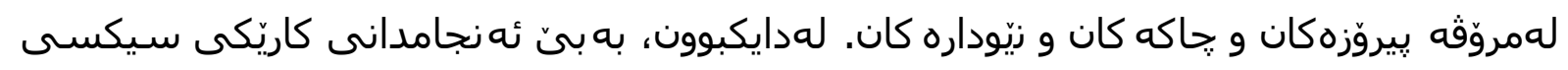

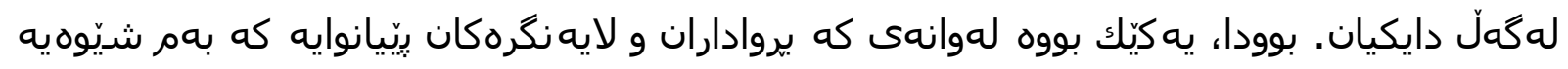

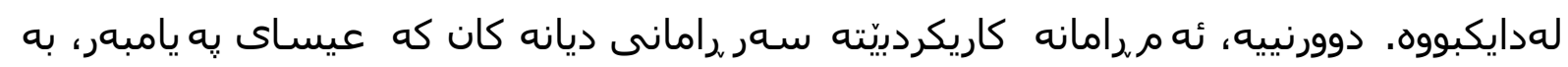

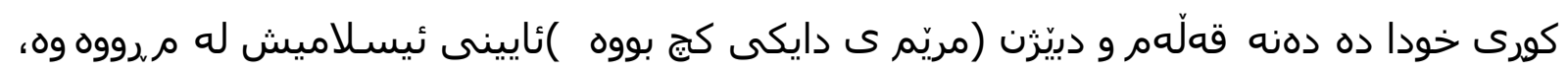

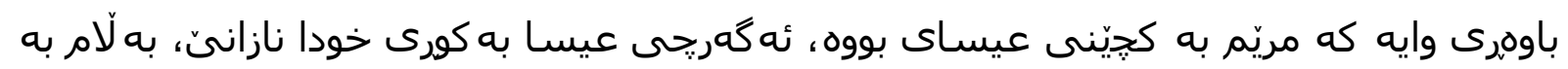

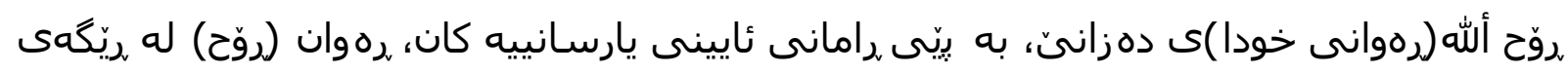


دوّناو دوّنه وه له جهستهيهكوه بوّ جه ستهيهكى ده كوازيّتهوه وه ههر به بِيّى باوه رى

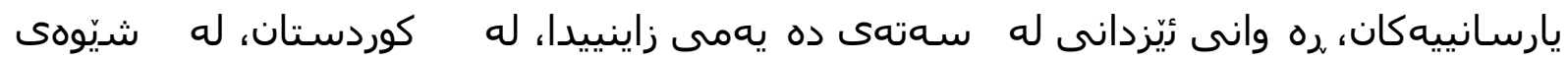

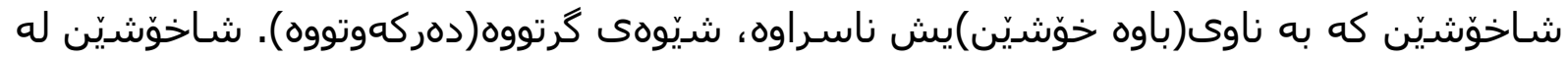

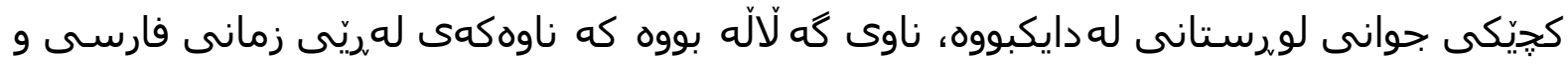
عaرهبييهوه كراوه به(جملاله).

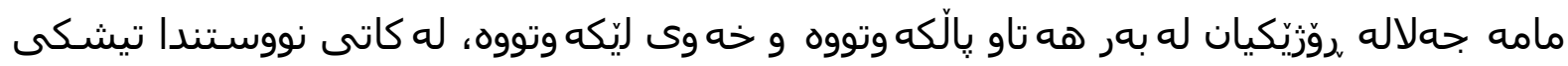
خوّر(كه خوّر زوّر يِيروّه لاى يارسانييه كان)يجووته دهميهوه و لهوهوه زگیى ير بووه ، زوّر ترساوه

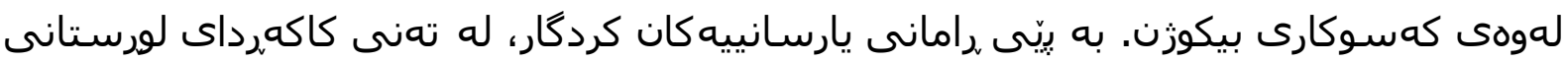

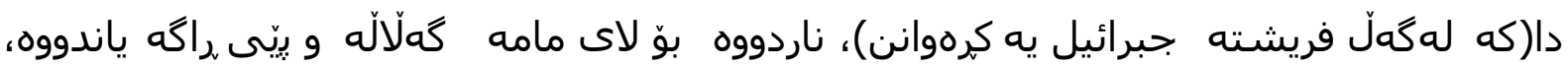

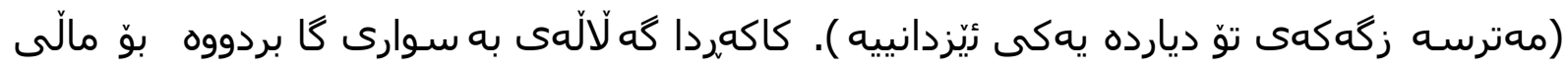

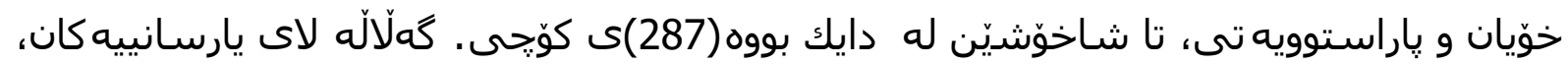

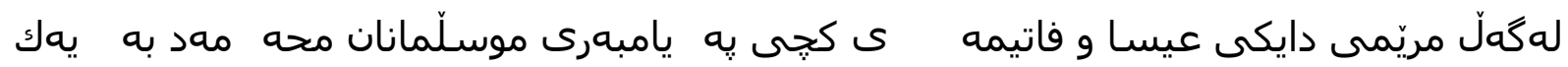

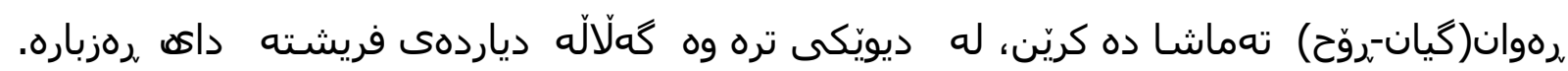

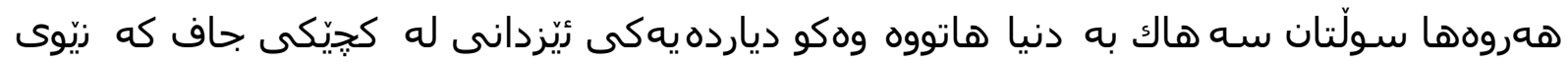

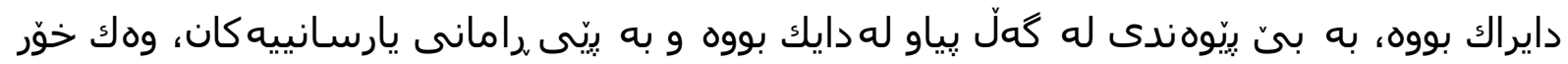

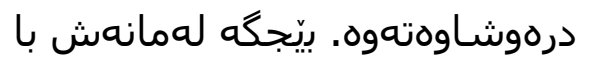

وه يادگاريش، ههر له كجِيْك له دايكبووه بهو شيّوهيه، كجه كه بهخواردنى دهنكه ههناريّك زگى

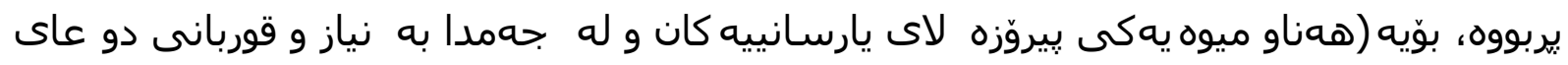

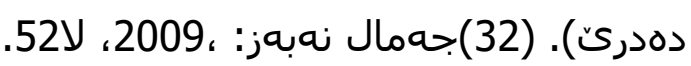

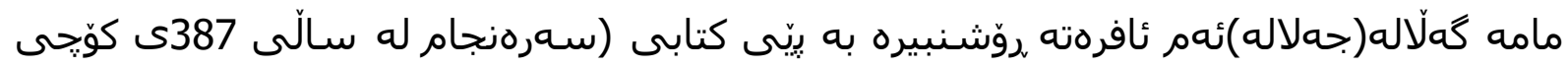

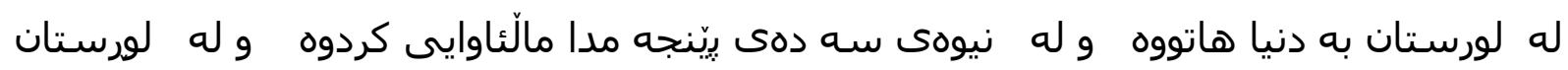

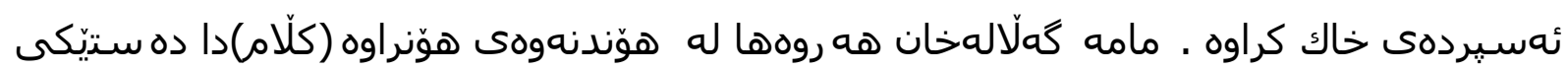

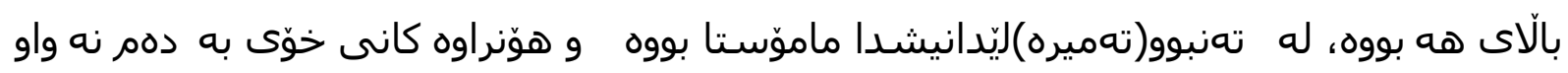

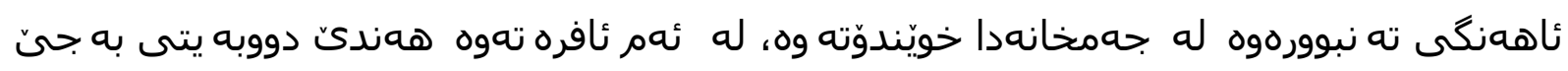

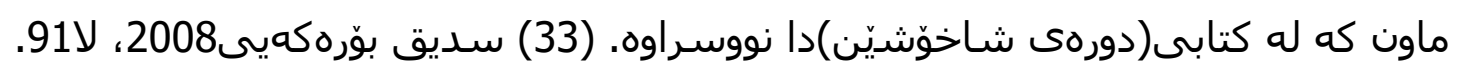

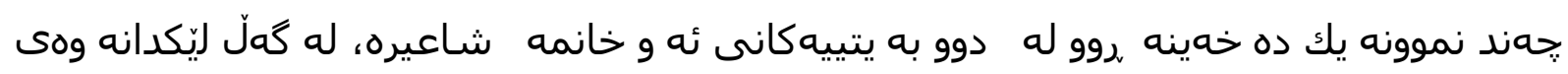
تيكستهكان: له (سهرهنجام)دا هاتووه له دهورهى شاخوّشيّن. مامه جهلاله وهكو هوّنه رانى تر

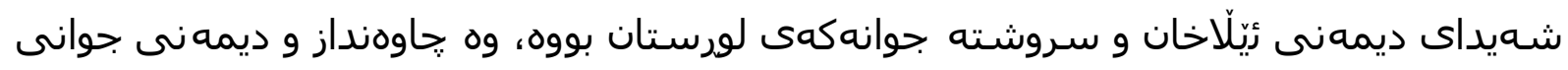

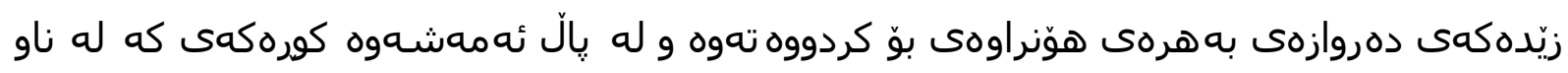

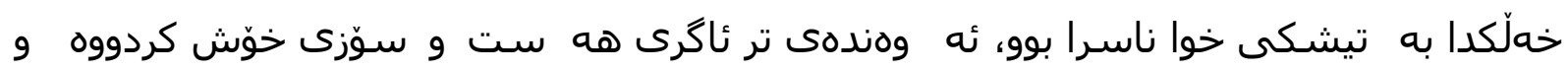

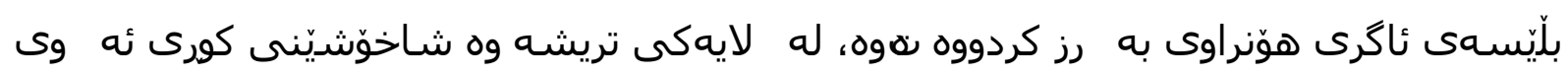

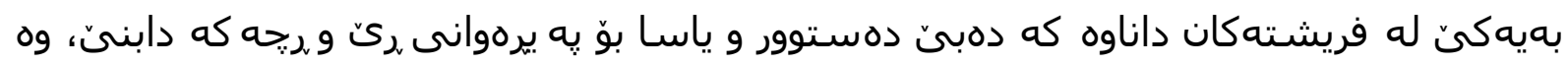


ئهمانه ههموو بووه هوّكارى ئهوهى كه جحلاله خانم هوّنراوه دابنين و ئاويّتهى سوّزى ده روونى

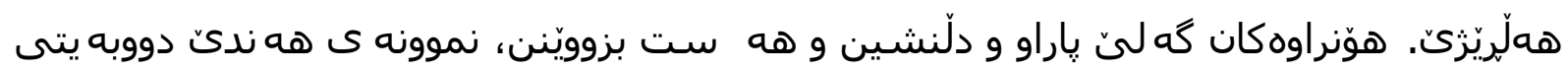
دهخهينه ،روو:

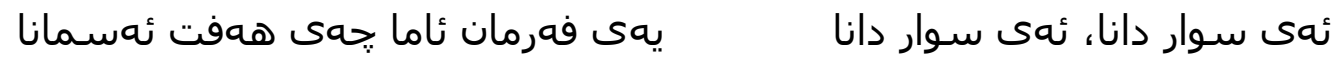

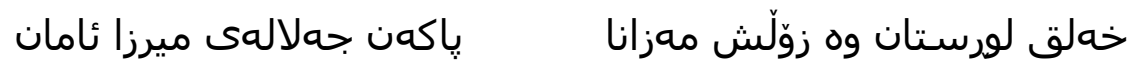

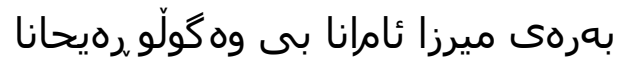

(34)تهيب تاهيرى2007)

واته: (ئهى كاكه ردا، ئهى شا سـوارى زنا، ئه مر فهرمانه كه له حهوت ئاسمانهوه هاتووه و كه

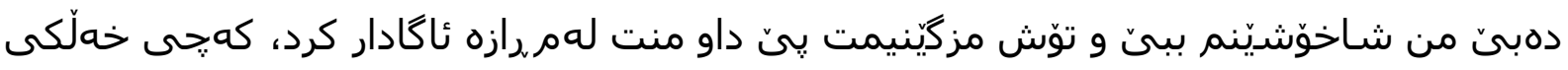

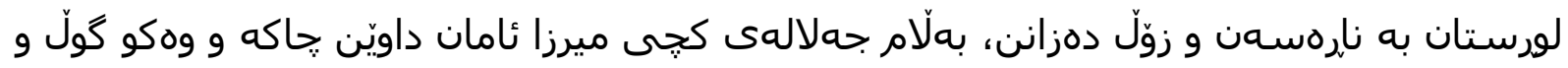

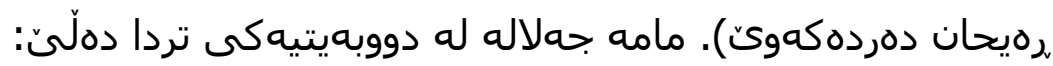

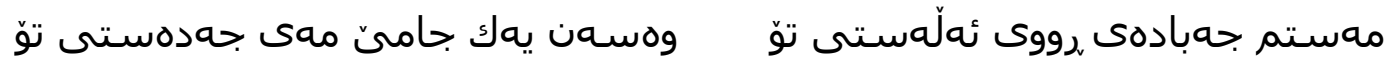

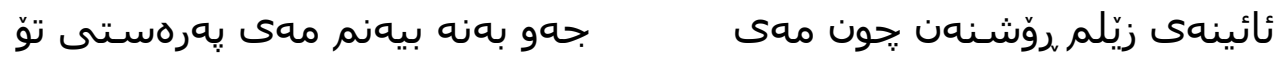

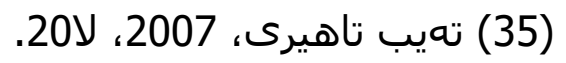

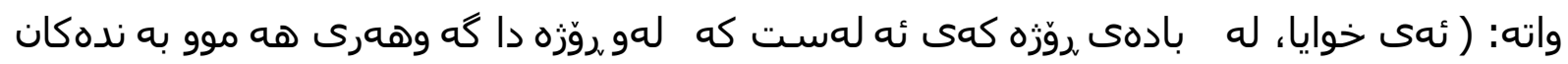

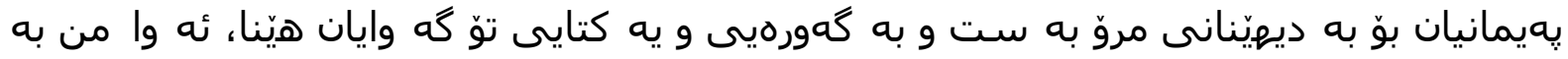
خواردنهوهى ئه و باده يه مهستم و ئه گهر ته نها جامى تر له و بادهيهم بدهيتى به سمه و ئه و

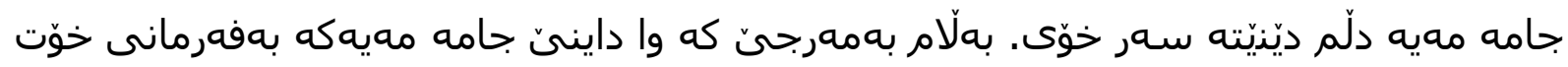

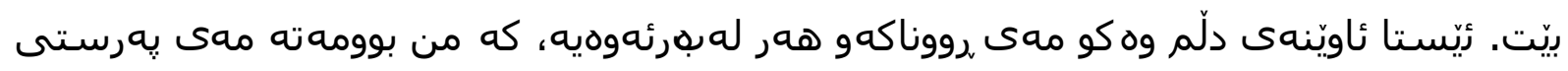
تو. نموونهى تريش زوّرن له هوّنراوهكانى ئهو ئافرهته هوّنه و ردوّشن دلّانهى وهكو مامه جهلاله و ئهوانى تر، بهلام ئيمه بوّ ههر يهكيّكيان تهنها جهند ديّريكك وهردهذكرين.

3. ـاتمه لورهى كَوّران

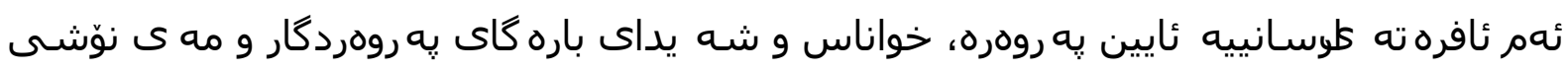
بادذى يهزدانى و ئهويندارى با تاهيرى ههمهدانى بووه، يه روهرده بووى رامان و هزرى عيرفانى

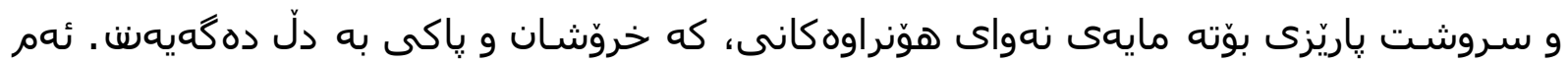

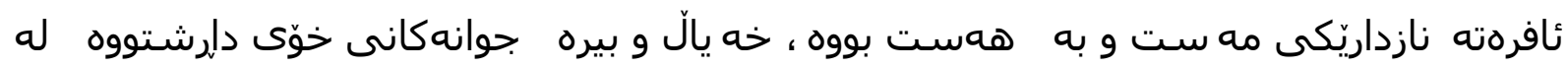
بوّتهيهى خوايهرستى دهرويَشانه.

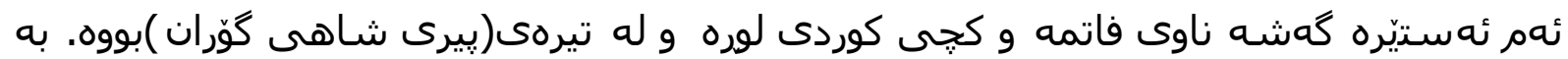

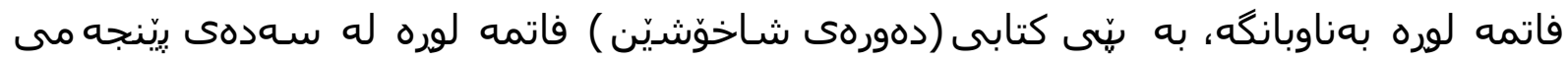

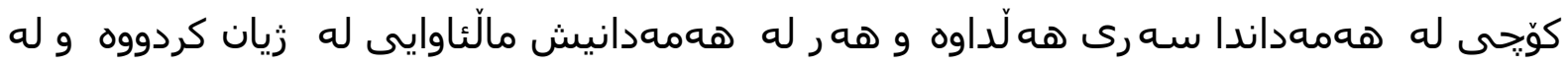
تهنيشت مهزارى، بابا تاهيرى هممهدان زيخراوه. 


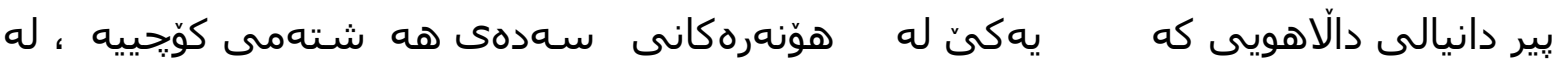

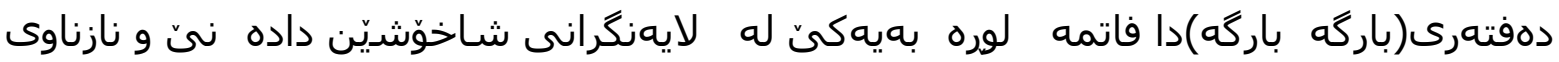

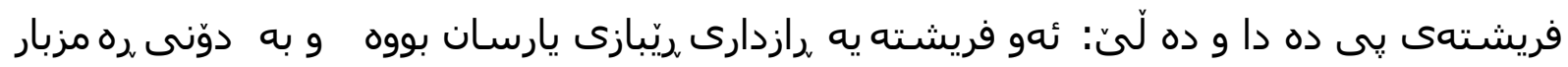

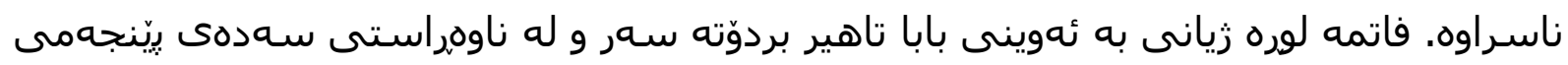
كوّيحهيدا شهرابى مهرگى له مهيكيّرى گهُدوون وهرگرتووه و خواردوويهتيهوه.

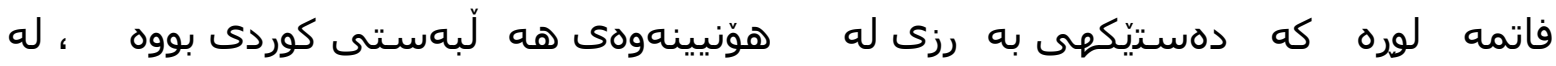

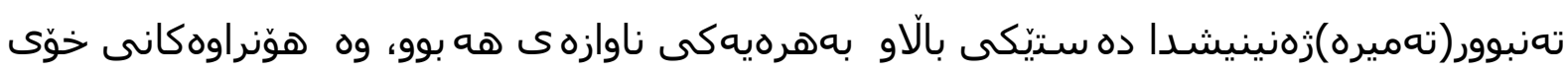

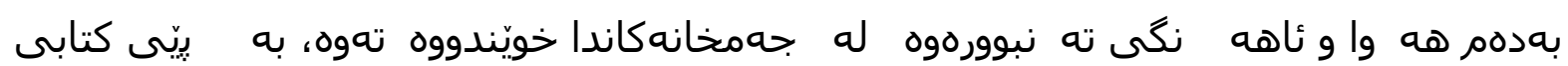

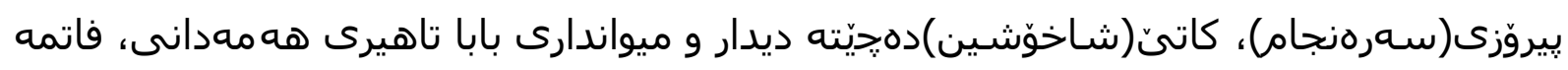
لوره له خانهقا خزمهتى كردووه لاى بابا تاهيرى ههمهدانى و له دووبهيتييهكيدا دهفهرمسن:

يارم ماهمانه، يارم مـمانه

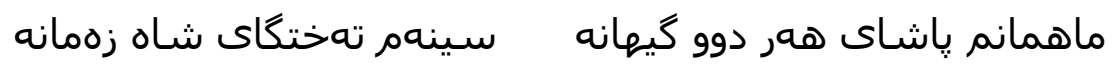

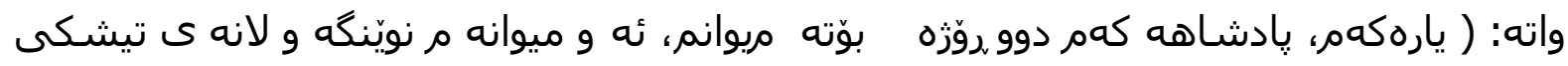
يادشاى ههردوو دنيايه، سينهم تهختگاى شاى زهمانه). هوّنهى يروادارى ئايينى يارسان بووه و و

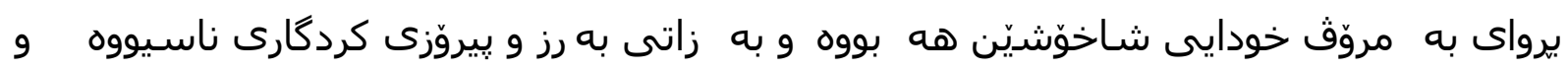

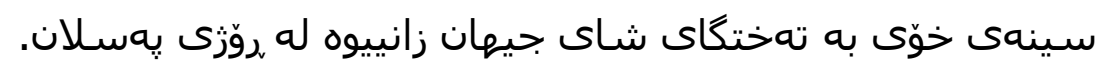

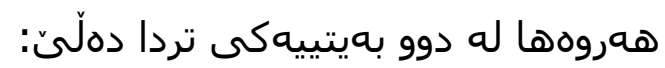

،رازدار ياريم، ،رازدار ياريم

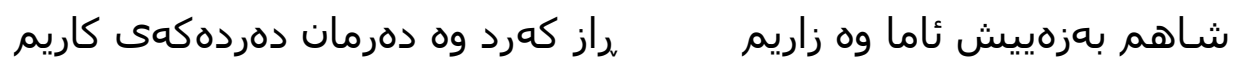

(سحرهنجام) دهورهى شاخوّشين.

واته: ( به فهرمان و ده ستوورى شاخوّشيّن، من دازدارى ريبازى ياريم، شا به زهيى هاتهوه به

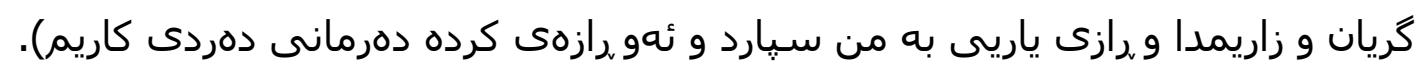

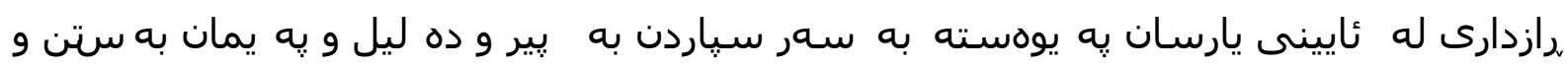

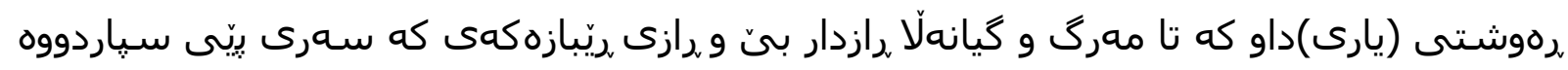
و يه يمانى به ستووه و سويّندى له سهر خواردووه ، به لاى كه سهوه نهيدركيّنى و ،راز ونهيّنى

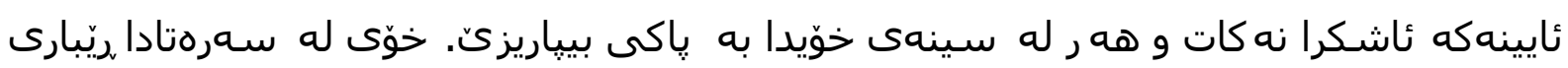

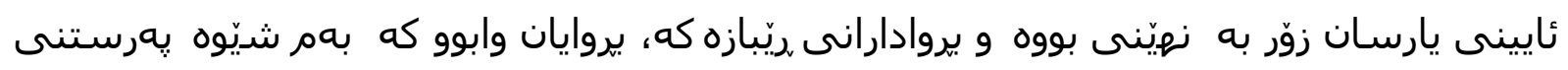

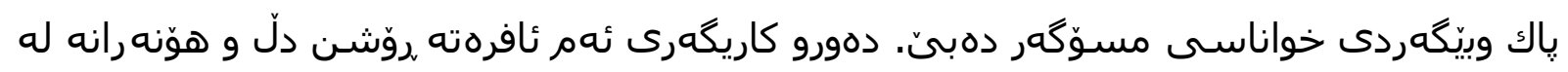

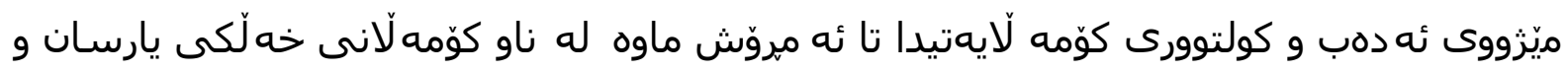

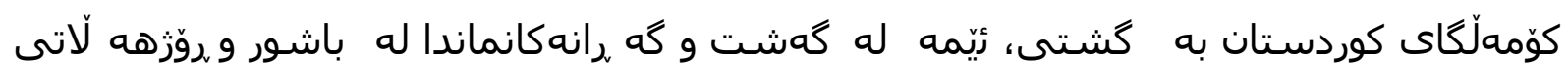

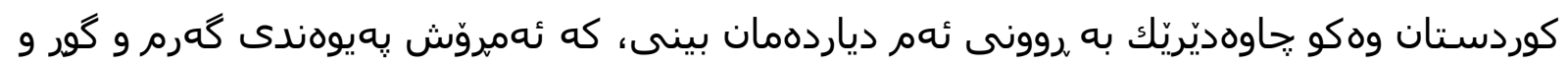

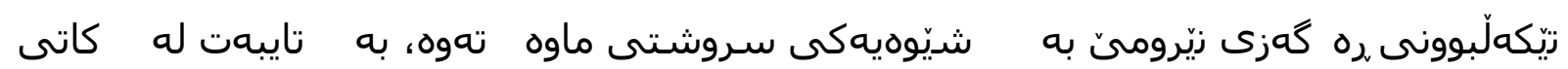


ئهنجامدانى نهزرو نياز و قوربانيكردن و كاره ههرهوززييه ئايينيهكان، كه به ئاشكرا ههست به

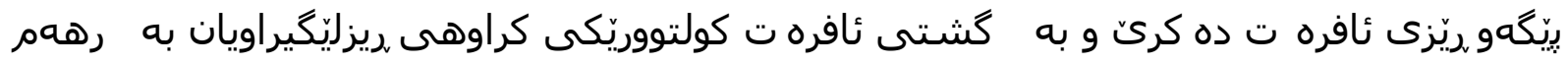

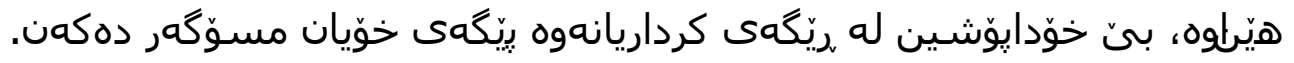

$$
\text { 4. خاتوون دايراكى ،رهزبار }
$$

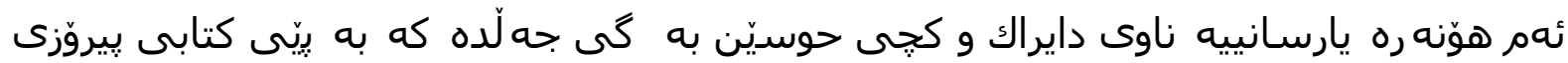
(سهرهنجام) له ناوهراستى سهدهى هه شتهمى كوّيحيدا له شارى حهلوان له دايك بووه، ههر له سهردهمى مندالّيدا باوكى ماموّستاى تايبه تى بوّ كُرتووه و لهلاى ئهو خهوريكى خويّندن بووه و پِاشـان پِووهته قوتابخانه و قورئانى يِروّز و كتابى ترى خويندوّته وه ئهوسـا فيّرى خه تخوّشيش

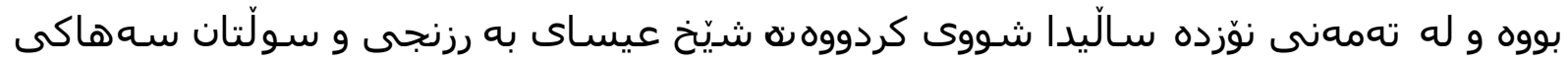

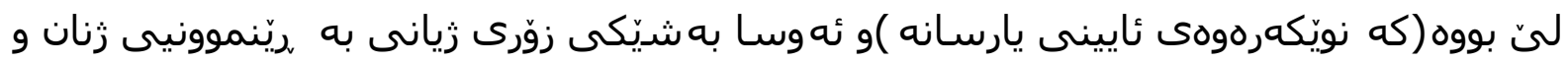

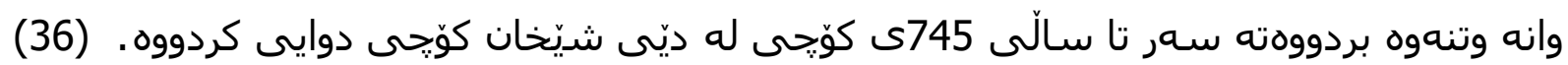

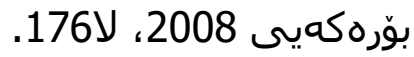

له كورتهى كتابى يِيروّى (سهرهنجام)دا هاتووه كه خاتوون دايراك، وه كو له بِيِشَوه ئامازهمان

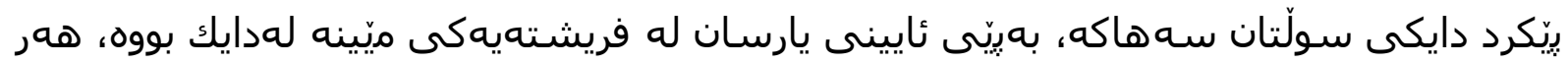
بهِيِيى ،رامانى يارسانييهكان له ههموو دياردهيهكى ئيزدانيشـا، فريشتهيهكى مرِينه، وهك ياريّك له يارانى ئيزدان ده ردهكووكّ. دهبين ئه وهش بزانين كه نهك هه ر يارسانييه كان به تهنى،

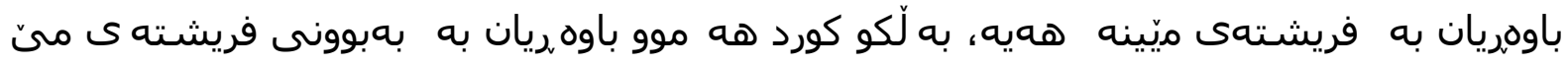

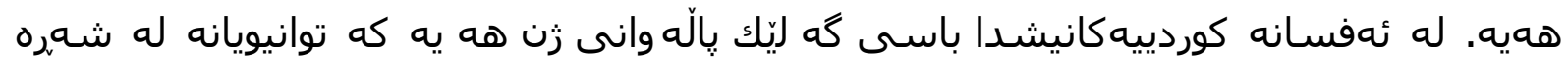

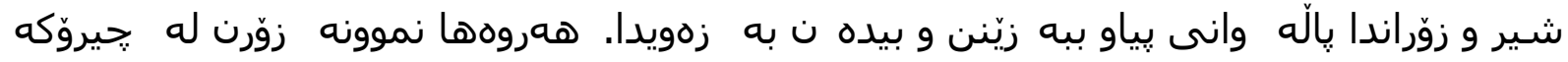

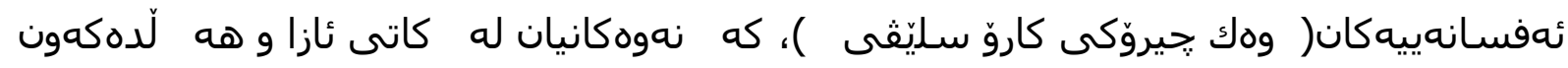

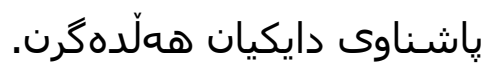

يرمان نه جِى كه خوداى خوّر ميّينه بووه و ئه وهته نيشانهى روّرّ له كوردى باكوردا نيشانه ى

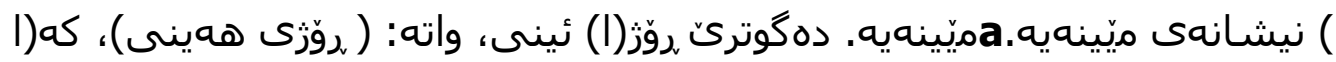

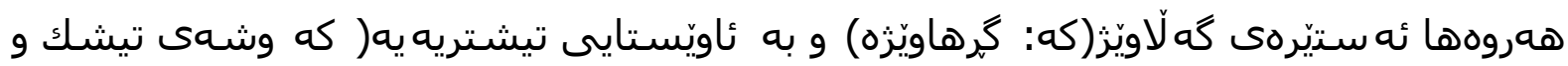
تريشقه لووهوه هاتووه) له ئايينى زهردهشتيشـا فريشتهيه. . (37)جهمال نهبهز،2009، لا58. زاهيرى خاتوو دايراك ز زيّكى يُاريزگًار و له خواترس بووه، كه له سهدهى هه شتهم زياوه و له

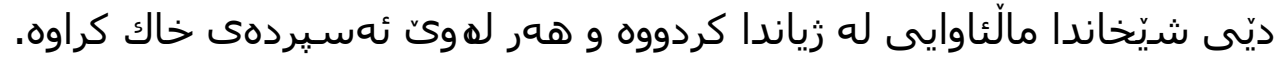

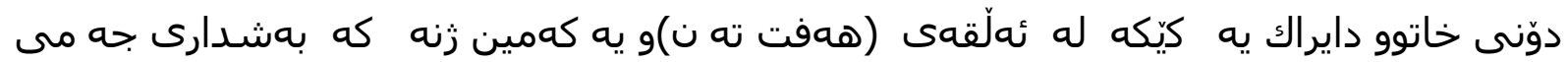

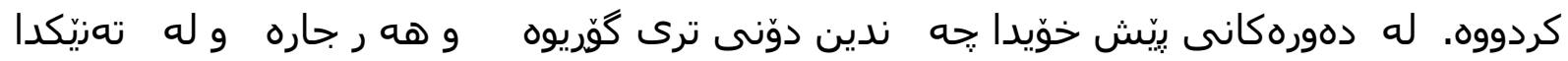

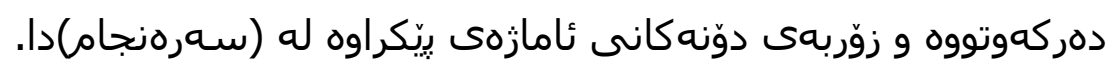


له خاتوو دايراك كه لنّ هوّنراوه بهجيّماون، كه له هوّنراوهكانى وا ده ردهكهون كه ئهوينى به كهوههرى هوّنراوه كانى زانيوه ، وه ك يارسـانيه ك يرواى به زيانى دوواى مردن هه بووه، بوّيه

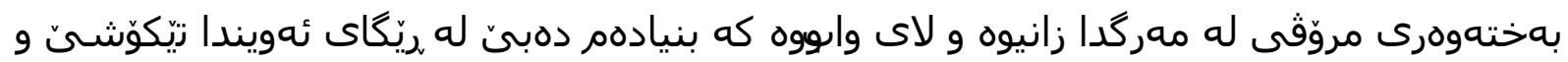

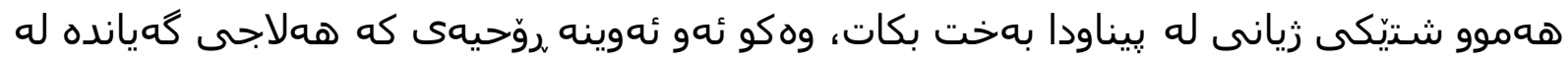
داردان! زوّربهى هوّنراوه كانى ئهو سه بارهت به ،ريّكاو ريحهى ئايينى يارسانن، خاتوو دايراك له

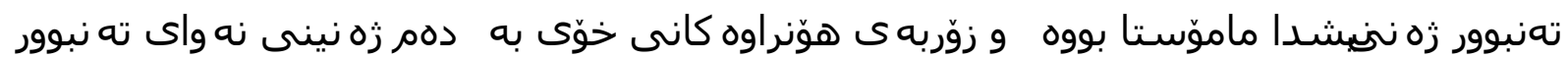

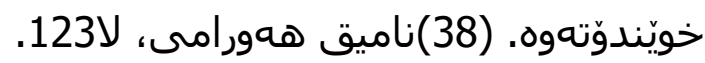

وا لِّره همندى نموونه له هوّنراوهكانى ديّنيينه وه به كورتى، له هوّنراوهيهكى دوازده دوو

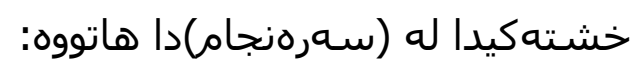

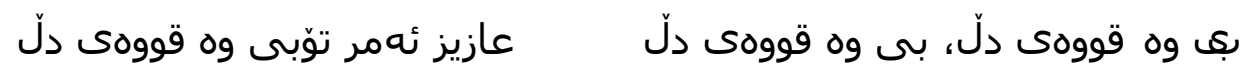

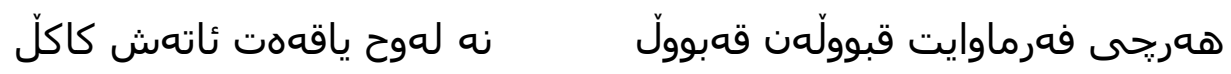

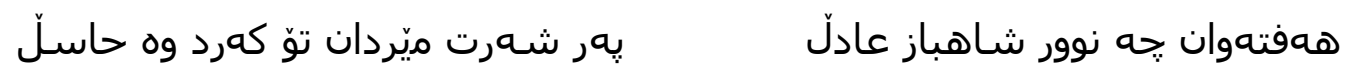

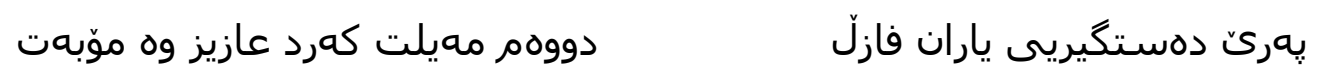

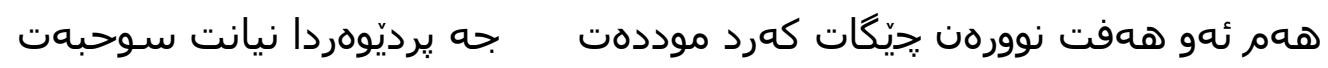

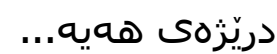

واته: ( ئهى خوّشهَ ويستهكهم، فه رمانى توّ بووه هيّزى دلّ، هه ريجى ده فهرمى يه سهندى

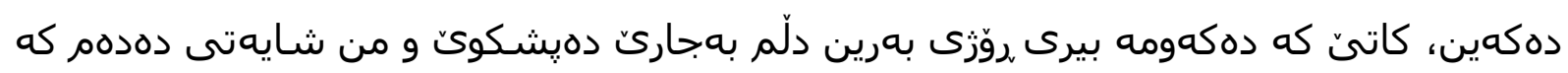

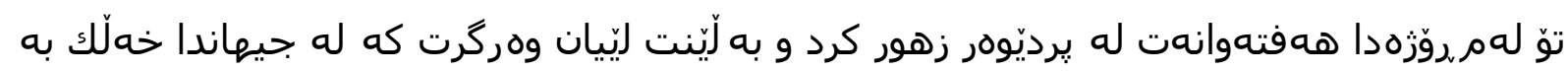

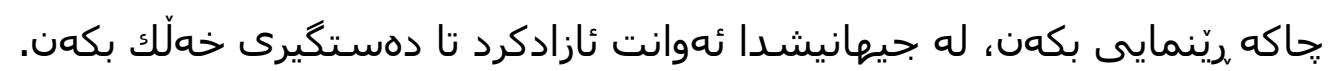

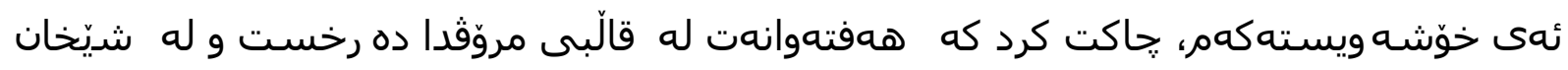
ديوانى مهولات سازدا، كهوابوو ههفتا و دوو يِر ده بن كيانى خوّيان له ريّى ئهواندا بهخت كهن

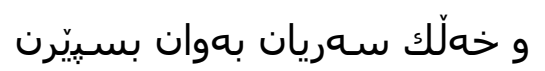

بهو بِيّيهى دايراك خاتوو دايراك يه كيّكه لهو ئافرهته رووشـن دلّه دإرشتنى جهمى بهستبِّت و و

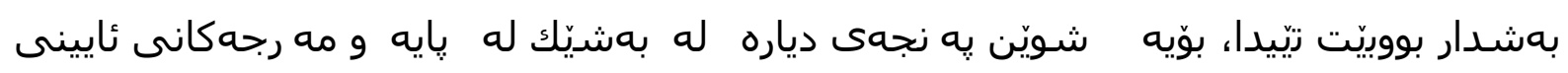

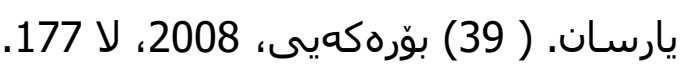

5. خاتوون زهربانوّى دهرزيانى

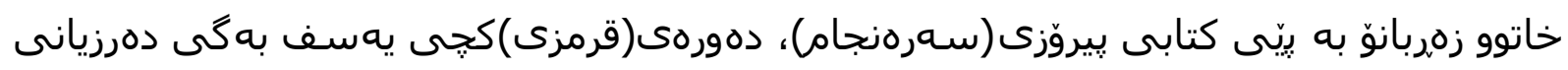

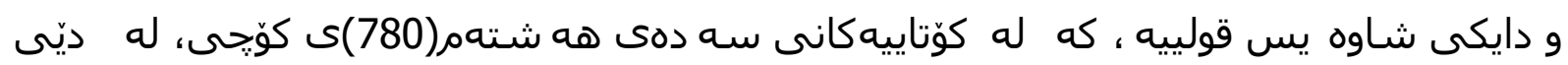

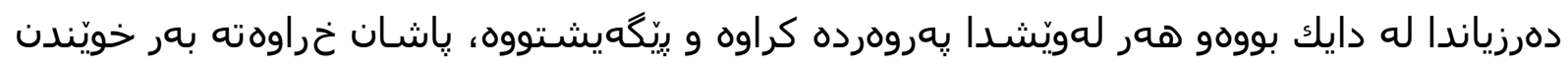

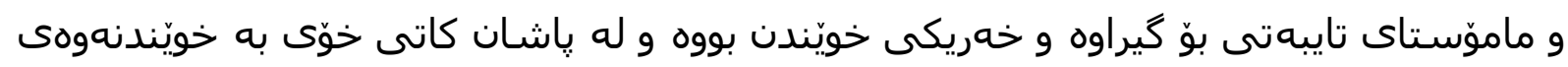

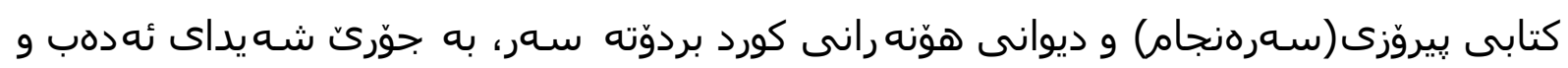


هونهر بووه كه له ياش ماوه يهك خوّى هوّنراوه ى هوّنمهوتهوه و نازناوى (خاتوون)ى بوّ خوّى داناوه، به بِيّى زانياره كان زوّر به خشـندهو و به زهيى و ميهره بان بووه و زوّر هاوكارى و ريّنويّنى

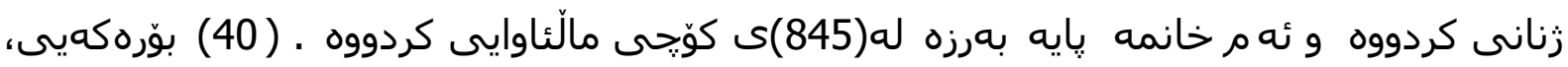
2008، لע387

خاتوو زهربانوى دهرزيانى له تهمهنى20 سالّيدا بوّته هاوسـهرى يِير قه نبهرى شاهوّيى، كه له دهورهى مورتهزا عهليدا دوّنى ميكايلى فلريشته بووه و له تهمهنى 30 سالّيدا كوريّكيان ده بيّت كه ئهويش(شاوهيس قولى)يه، كه يِينجهمين دهركهوتهى زاتى خودايييه . له دهورهى(قرمزى)،

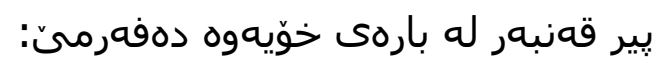

ئهسلّمهن جه كورد، ئهسلّمهن جه كورد با بوّم كوردهنان، ئهسلّمهن جه كورد

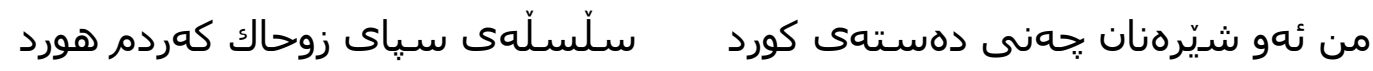

واته: ( من ئهسلّم كورده به باوانمووه، من له دوَزيّكما بِيِشتر، ئهو شيّره بووم لهَّلّ كورده كان

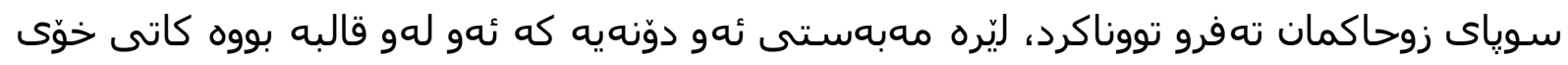
به بِيّى ردامانى ئايينى يارسان. ههندى هوّنراوه له شاوهيس قولييهوه ماوهتهوه و له دهفتهريّكدا به ناوى(دهورهى قرمزى) كوّكراوهتهوه و يِاريزراوه.

(41)ناميق هوروامى، 2011، لا 140.

خاتوون زه ربانوّى ده رزيانى جكه له هوّنينهوهى شيعر له زهنيينى ته نبوور(تهميره)شدا

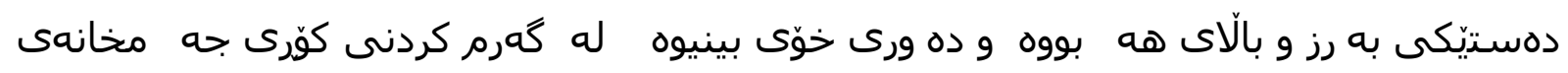

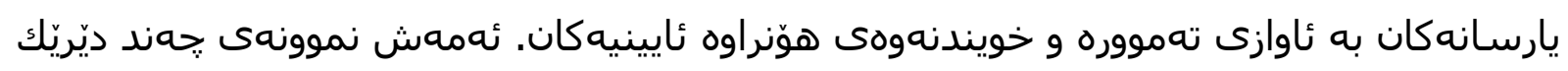
له هوّنراوهكانى:

كرد بييهن رزوان، كرد بيهن رزوان كارخانهى خواجهم كرد بيهن رزوان

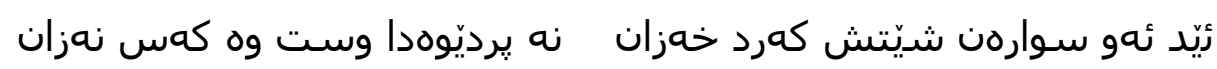

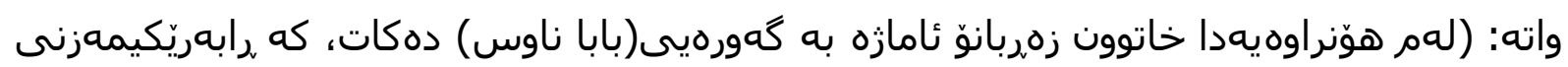

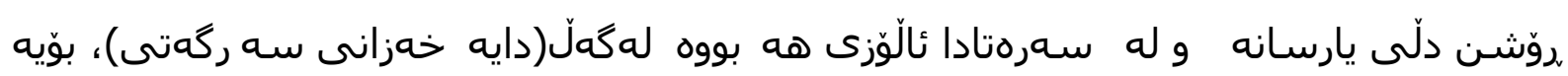
مهبهستى ئه وهيه كه همموو ياران له دهورى رابه ر و سموروّكمان جوم بووينه تهوه و ئه و ئه

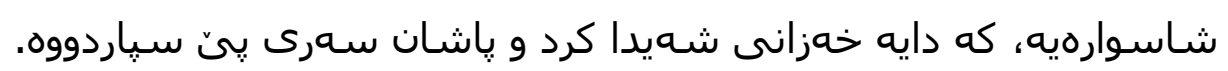

دoرos

لهم تويّزينهوهدا گهيشتين بهم دهرهنجامانهى خوارهوه:

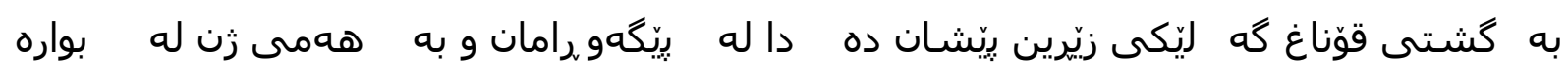

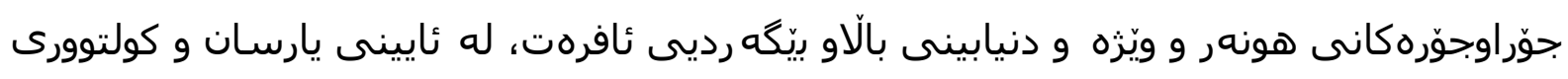

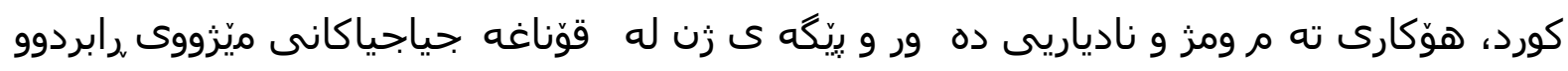




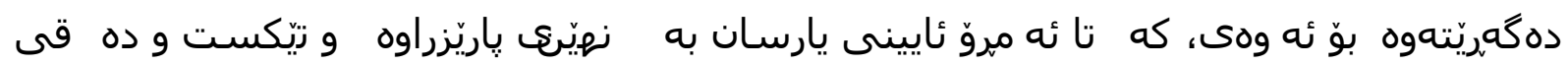

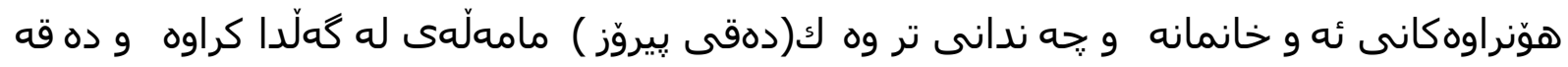

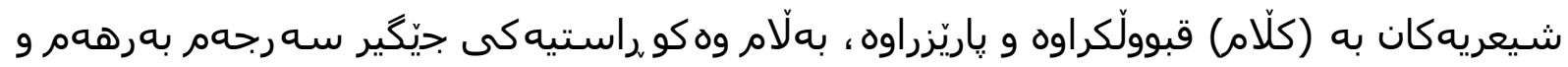
تيّكست و كارى هونه رى رابردوو به بهشيّكى به هادار و نه مرى كولتوورى كورد ده زميّردرى و و بِيْويسته كارى زانستى زياترى لهسهر بكرى

لهم تويزينهوهيهدا تيشكمان خسته سهر ئايينى يارسان، كه ئاييزيّكى سهربهخوّى كورديه و له

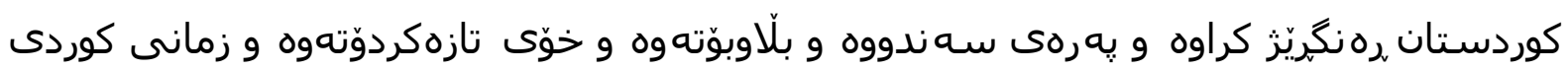

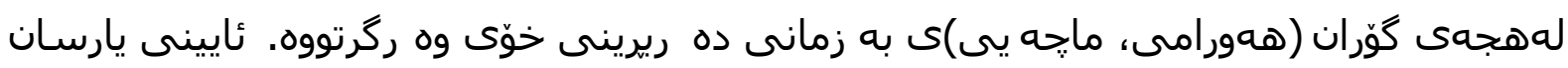

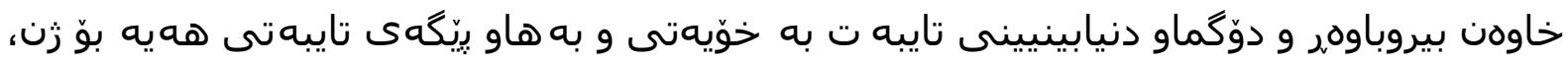
له دهورهكاندا به دريّزايى ميّزوو ئافرهت دهورى گرنگى بينيوه له بوارى نووسين و رابه ريكردن و و

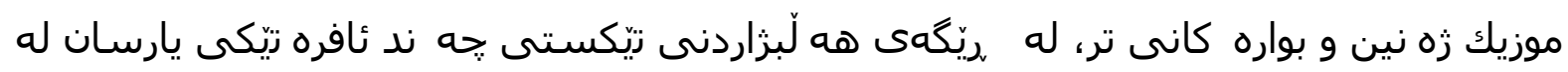

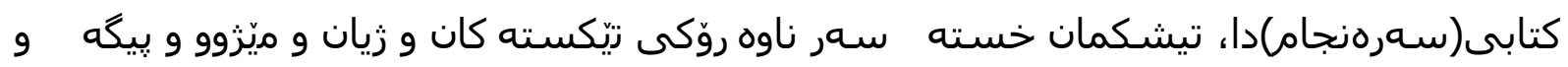

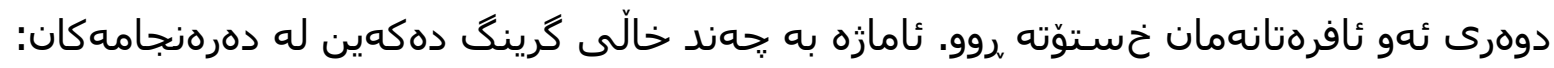

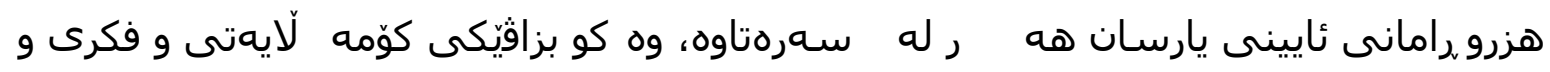

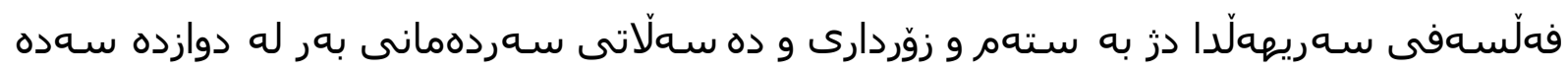

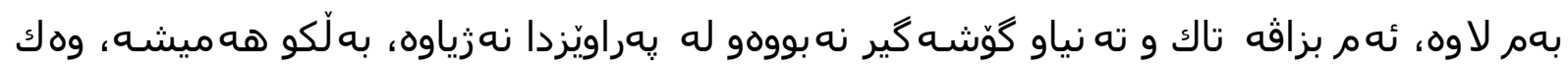

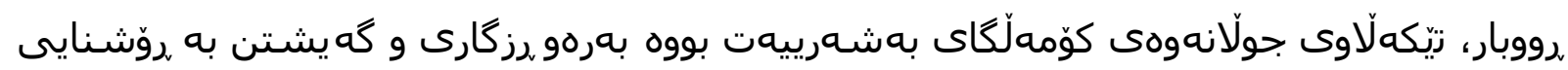

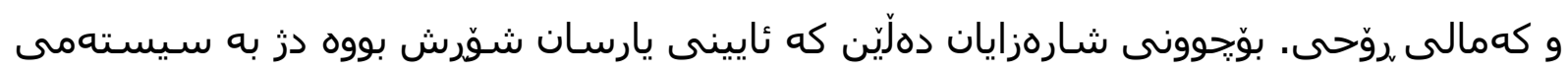

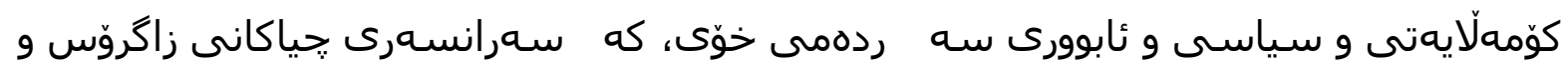

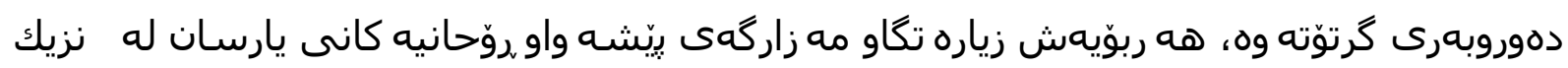

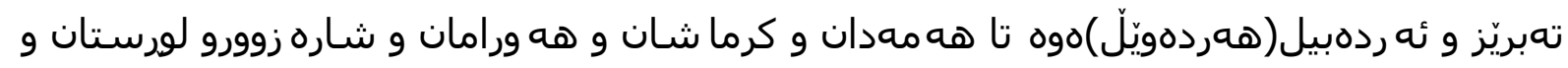
بهغداو كهركوك و موسلّدا ههنه و رن بهشيّكى كاراو زيندووى ئهم خهبات و قوربانيدانهيه بوونه.

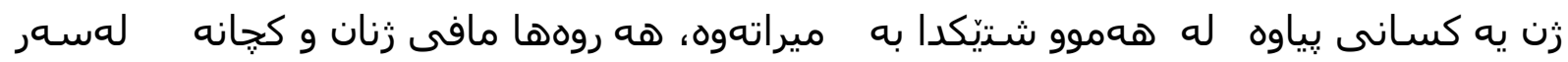

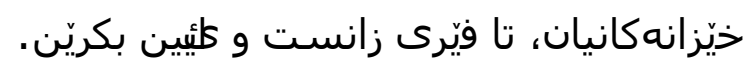

ئهو ئافره تانهى زيّمه لهم تويّزينه وهدا هه لْمانبزاردوون، كوردن و له كوردستان به دنيا هاتوون و سهر به ئايينى يارسانن، تيكسته كانيان له كتابى سه رهنجام ياريزراون و وه كو دهقى يِيروز له له

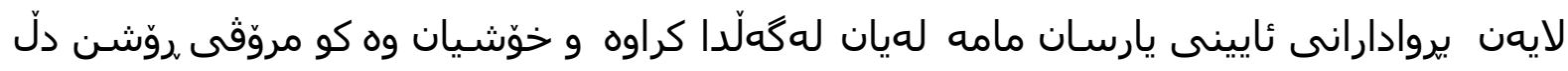

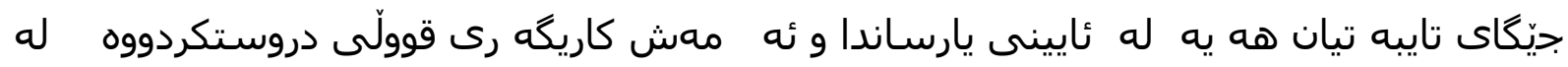

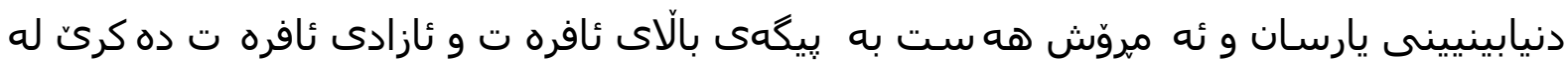
كولتوورى كوردييدا . 
ئافرهت له ئايينى يارسان بِيَكهى بهرز و تايبهتى خوّى ههيه. بوّى ههيه، وهكو پِياو، به بهرزترين

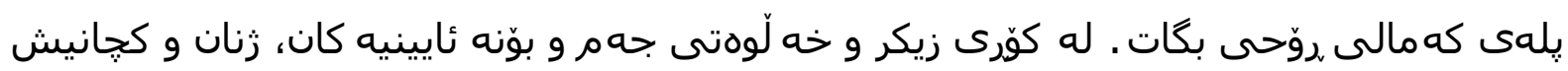
״الاّكانه بهشـار ده بن و موزيك ده زهنن و سرود ده خويننن و خزمه ت ده كهن. له دهورهكانى

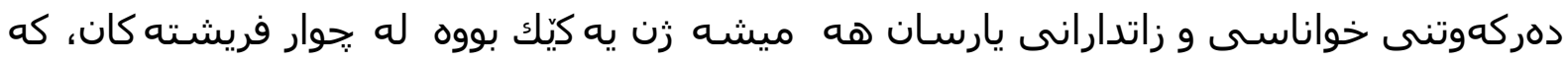

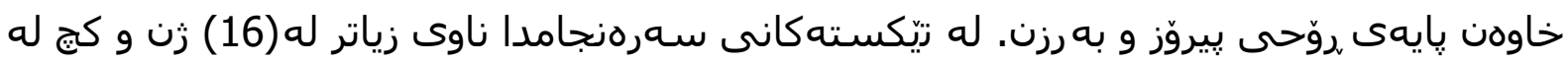
ناو دوّحانى و گهوره ياراندا هاتووه، كه ههنديّكيان تهميره زهن(موزيك زهن)وخويّنهرى به ئاوازى رئه سـرود(كلّام)كانى يارسان بوونه و شان به شـانى بِياوان سـرودى سوّفيگه رى عيرفانيان داناوه

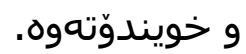

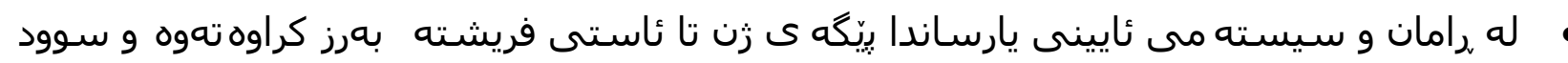

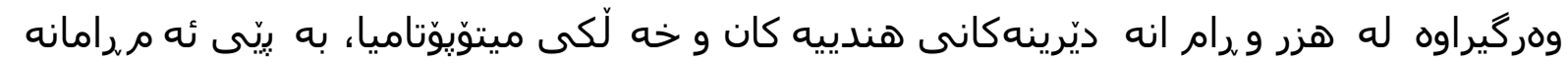

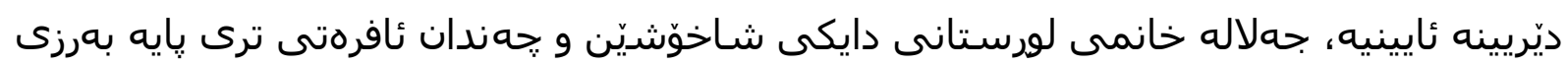

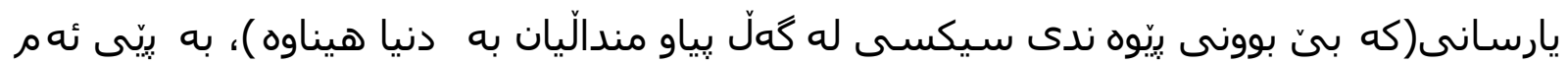

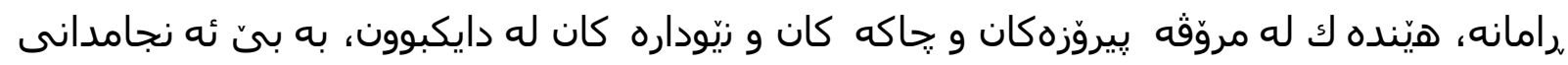

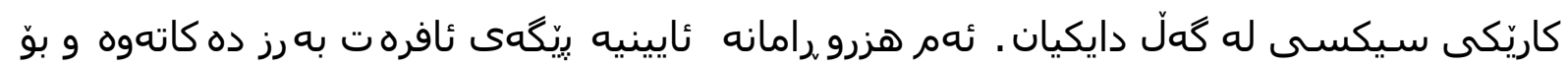

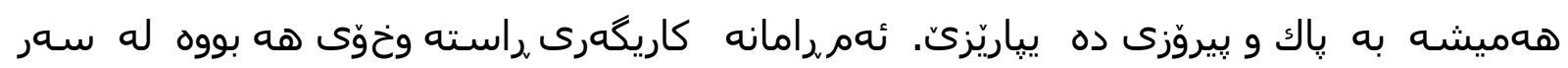

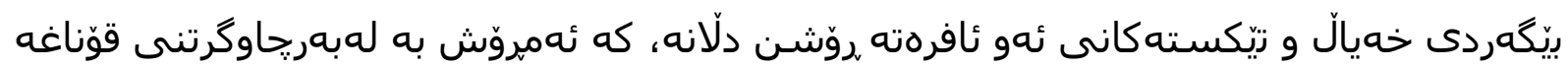

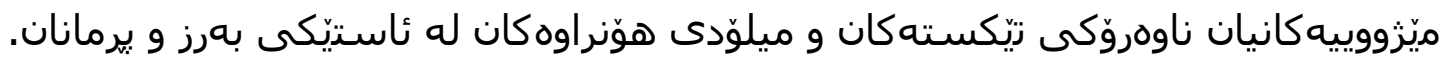

له كوّتاييدا زوّر گرنگ و بِيّويسته تويّزينهوهى زانستى زياتر بكرى و گرنگى به ئايينه كورديهكان و

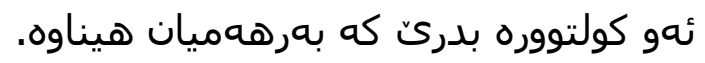


خلاصـة

يارسان هي ديانة كردية قديمة مبنية على الاسس الدينية العريقة في كردستان مثل مير اتي و الزردشية وغير ها من الديانات الاخرى ـ ان (سرنجام ) هو الكتاب المقد لدى ديانة يارسان ويعتبر كجزء اصيل من التراث القومي الكردي ويحمل بين طياته المر اسيم الدنوية الخاصة بها وان هذه الديانة وجدت جنبا الى جنب مع الديانات الاخرى العالمية المعروفة وكما انها استطاعت من تطوير وتجديد نفسها باستمر ار .

وفي هذا البحث حاولنا تسليط الضوء على المكون النسائي في مجال الكتابة والموسيقى و التربية الدينية في ديانة يارسان على مر التاريخ. وبغية اثر اء الموضوع بمزيد من المعلومات تمت الاشارة الى عدد من النساء المثقفات المعروفات و التي ذكرت كامثلة في الكتاب المقد (سر انجام) واللاتي وصلن الى مرتبة عالية جدا من المعرفة ونم تفسير قصائدهن الدنيوية وكما انهن لعبن دورا كبير ا في المجنمع جنبا الى جنب مع الرجال لخدمة ونشر رسالة تللك الديانة وكما انهن ساهمن

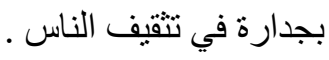

سa, ساوهكان:

( 1) جهمال نهبهز: فهلسهفه و رامانى يارسان ، ههوليّر،2009 ل35.

( 2)مارف خهزنهدار: ميّزووى ئهدهبى كوردى، بهرگى يهكهر، ههوليّر 2010، ل 254.

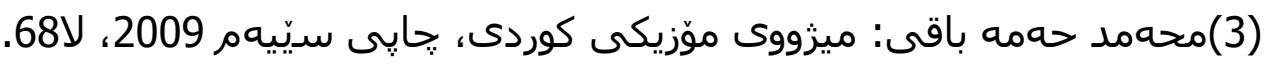

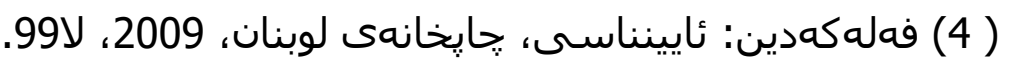

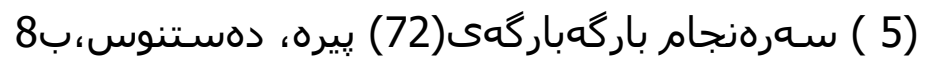

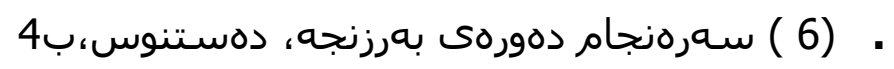

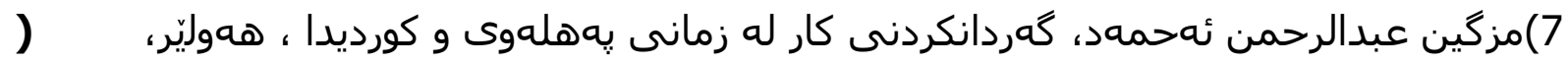

2006، 272

(8) فهمهى كاكهيى . دهروازهيهى بوّ ناسينى ئايينى يارسان ..روّزنامهى باس . رماره 126. 2013.

.(9) تهيب تاهرى: تاريخ و فهلسهفهى سهرهنجام، :حايخانهى روّزهملات، 2009، ل589.

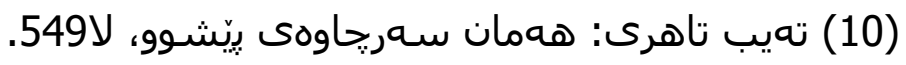

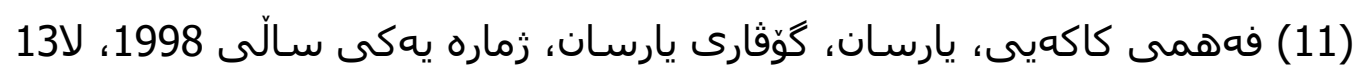

(12)رشاد ميران، ردوشى ئايينى و نهتهوهيى له كوردستان، 2017، لا 192.

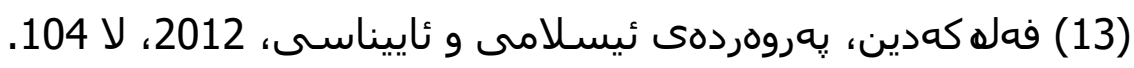

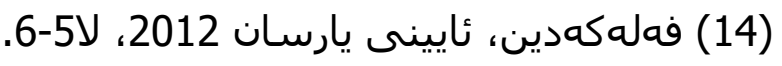


(15) تهيب تاهيرى، تاريخ و فهلسهفهى سهرهنجام، هووليّر 2009، لا577.

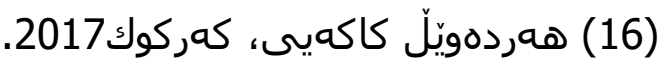

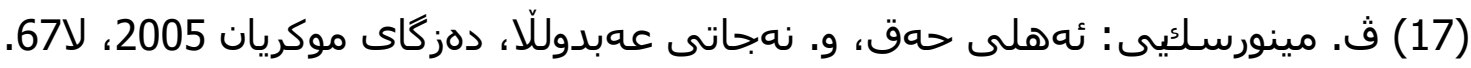

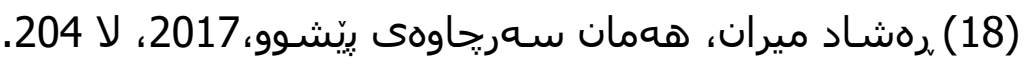

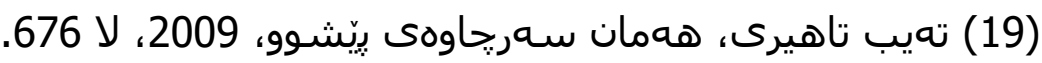

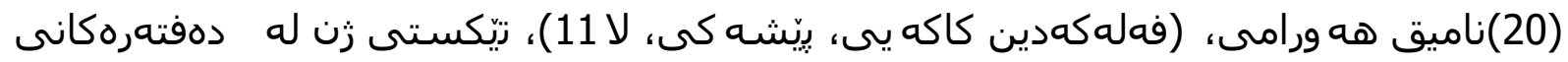

يارسان، هووليّر2011.

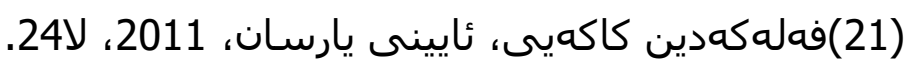

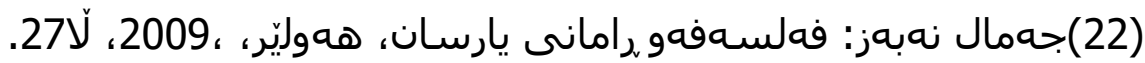

(23) فهلمكدين كاكهيى، ئايينى يارسان، هووليّر 2011، لا 25.

(24) هوياس، هووليّر، (15. 4. 2017).

(25) ههردمويّل كاكهيى، كهركوك، (2016.2016) (11.3.).

(26)تهيب تاهيرى، سهرهنجام، 2007،لا 62.

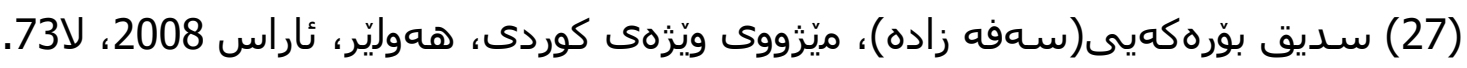

(28)تهيب تاهيرى، كتابى سهرهنجام، 2007، لا 63 .

(29)ناميق هورامى، زيّكستى زنان له دهفتهرى يارساندا، هووليّر 2011،لا 81.

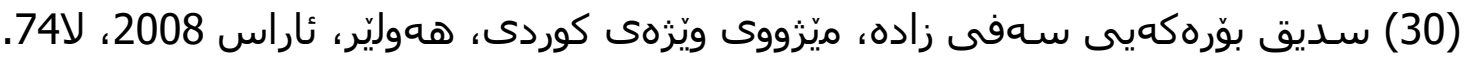

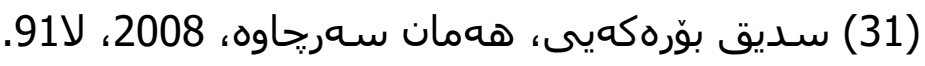

(32)تهيب تاهيرى، سهرهنجام، 2007،لا 56.

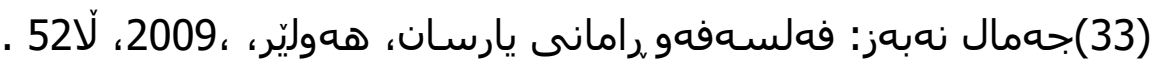

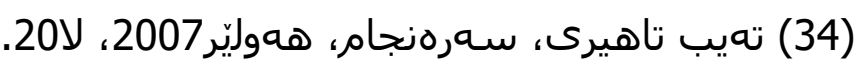

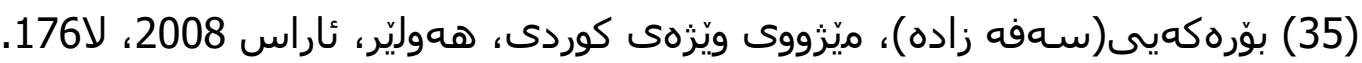

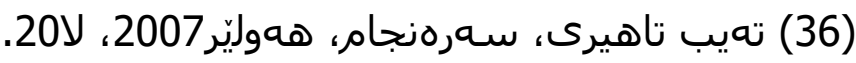

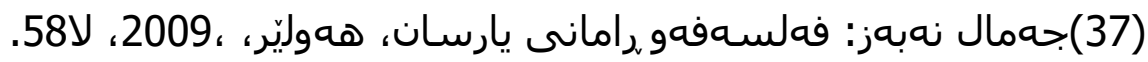

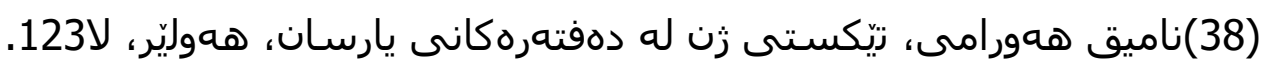

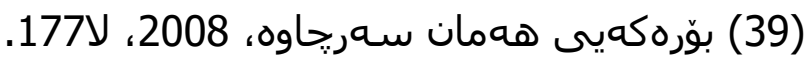

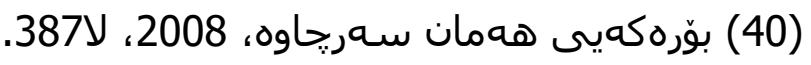

(41)ناميق هوورامى، تيكستى زنان له دهفتهرى يارساندا، هووليّر 2011، لا 140.

سهر:جاوهى تركه سودى ليّوهركيراوه:

1. سهرهنجام: كتيبى ئايينى بِيروّى يارسان. 
2. تهيب تاهيرى: تاريخ و فهلسهفهى سهرهنجام، جايخانهى روّرَهَلات 2009.

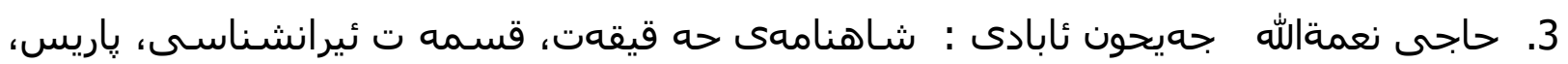

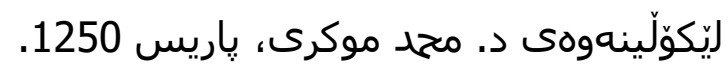

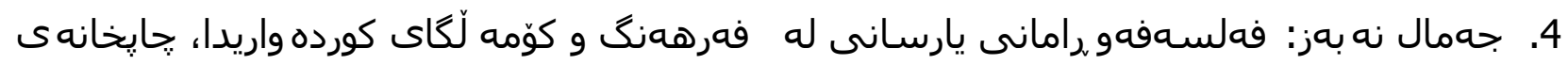
ناره 2009. 5. د. كَلّموراد مرادى: نيكاهى كوزارا به ميّزووى فهلسهفهى ئههله حهق(يارسان)، سويد 1990.

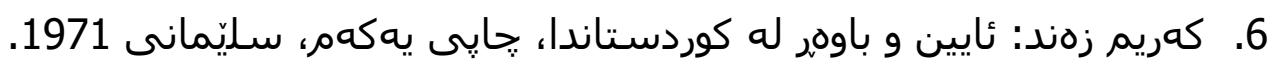

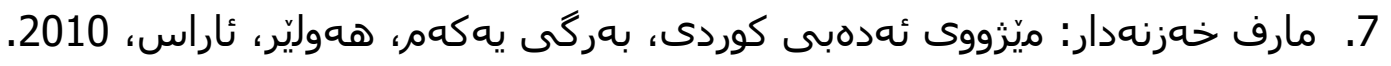

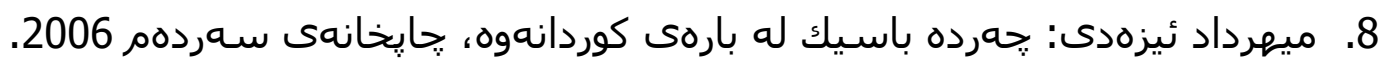

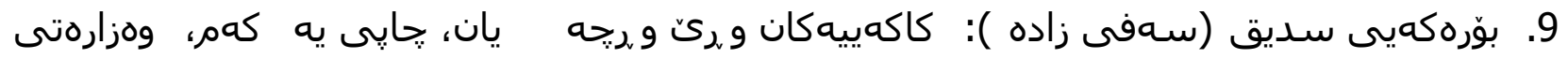
،ووّشنبيرى 2001.

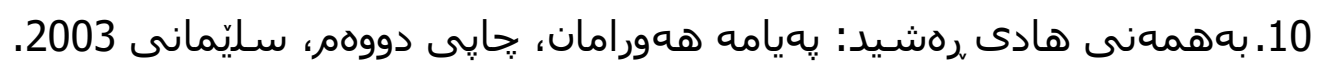

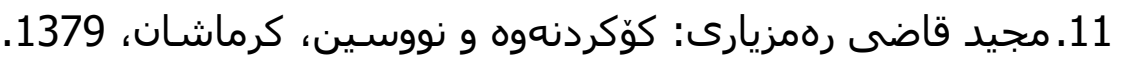

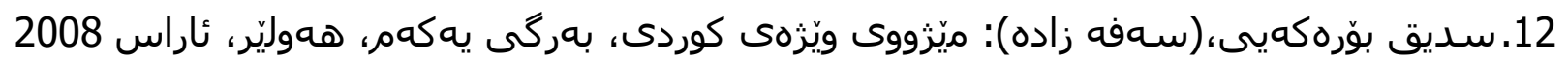

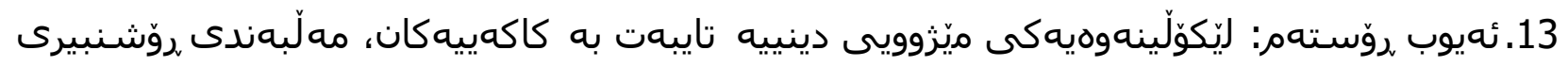
هوورامان، 2006.

14.تهيب تاهيرى: زهبورى حهقيقهت، كرماشان، 2013.

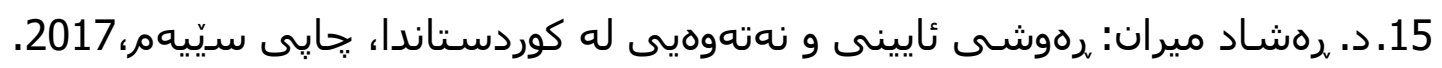

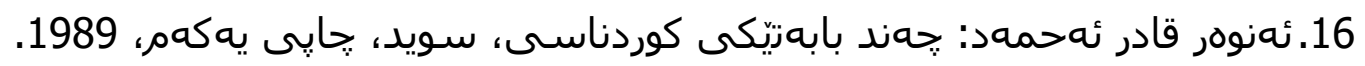

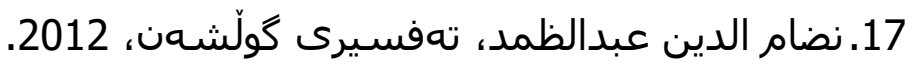

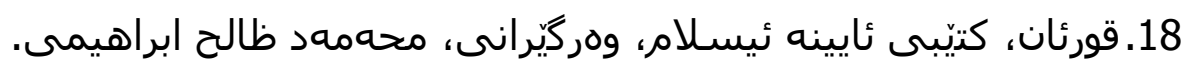

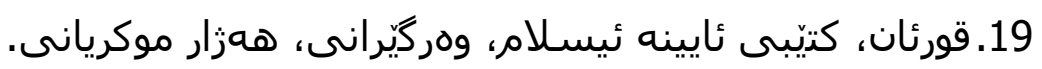
20.سيد محهمد حوسيّنى: ديوانه كهوره، كرماشامو 1382.

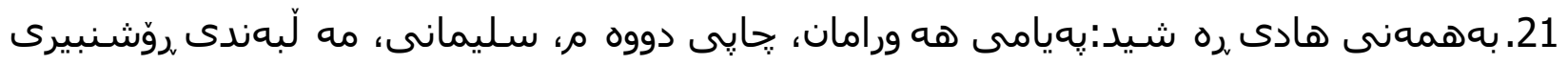
هوروامان 2003.

22. د. كُولموراد مورادى: ئوّلهانى جيهان، ،. ناسرى رهزازى، هووليّر، ناراس، 2010.

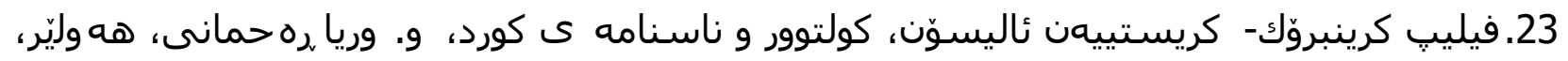

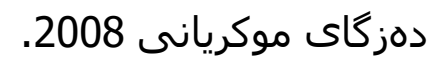

24.فهلكهدين كاكهيى: ئايينى يارسان، هووليّر، 2011.

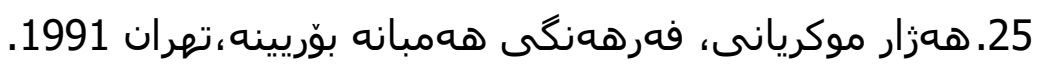

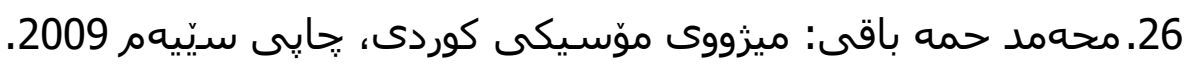
27. د. كيومهرس عهزيزيمى: ميزووى شيعهذهرى له كوردستاندا، تاران، 2017. 
28. حمهكهريم محمود: كوردستان له بهردهر فتوحاتى ئيسلاميدا، سليّمانى، 2006. 29. گهرميانى ئاسوّو ئامهد تيكريس: كورته ميّزووى كورد و كوردستان، سويد، 1992.

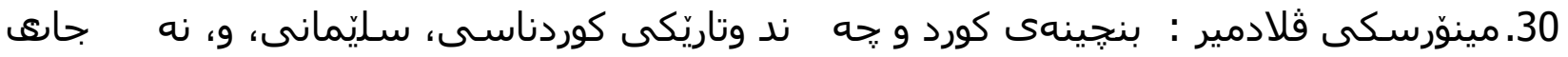
عهبدوللا، مهكتهبى بير و وشـيارى. 31. كومون فرانتس: نهيِنيه كانى ئايينى ميترايى، و، فهرهاد عهزيز خوّشناو، هووليّر، موكريان 2008. 32.سيدحهسهنى تهقى زاده: مانى و دينهكى، :حإِى يهكهر، هaوليّر، مناره، 2005.

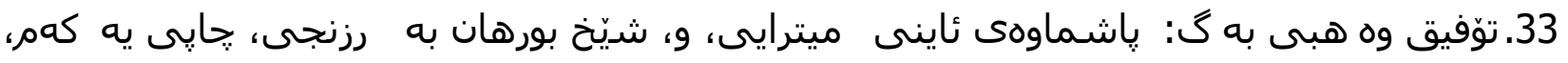

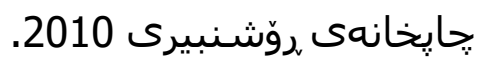
34.ن ئيثانوَقا : بِيِرهوانى ،راستى، يارانى كوردستان ( ئههلى حه ق)، و، ئاسوّ كه ريم، هه وليّر، .2003

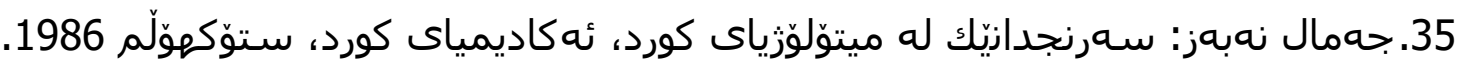

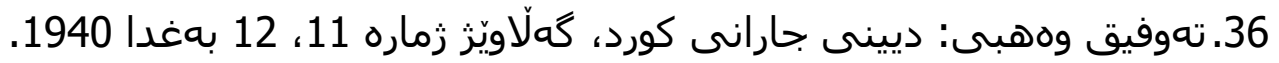

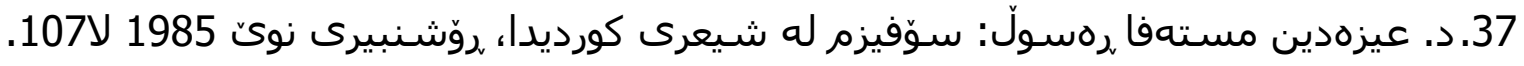
38. كهريم زهند: ئايين و باوهرله كوردستاندا، سـليّمانى 1971.

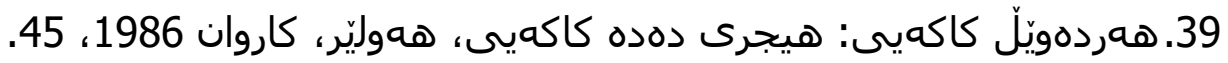
40.ئهمين شيّخ عملائهدين نهقشبهندى: تهسهوف خييه، بهغدا 1985؟ 41. محهمهد ئهمين هوروامى: كاكهيى، بهغدا 1984.

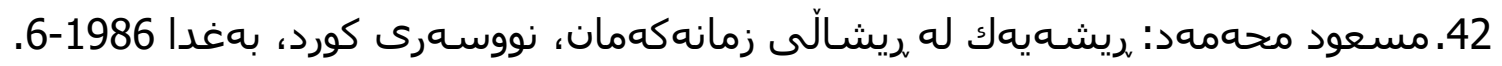
43.شاكر فهتاح: يهزيدييهكان و ئايينى يهزيدى، سليّماه 1969. 44.مستهفا عهسكهرى: ئاوردانهوهيهك له بزووتنهوهى همقه، بهغدا 1983. 45.عبدوالقادر دهباغى: جهند ديّريكك له ميزروودا، بهشى يهكهر، كاروان، 1987- 54. 46. جهمال نهبهز: زمانى يهكگرتووى كوردى، بامبيرى 1976. 47.مهلا عهبدولكهريمى مودهرس: ديوانى مهولهوى، بهغدا 1961.

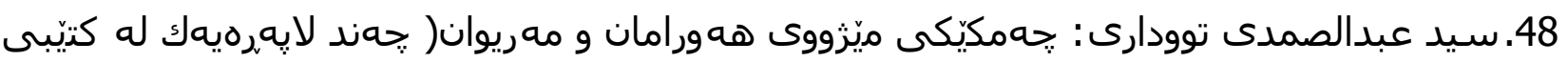
نور النوار- محهمهدى مهلاكهريم وهريكيّيراوهته سهر كوردى، بهغدا مهيد 1970. 49. محهمهد ئهمين زهكى: خوّلاسهى تهئريخى كورد و كوردستان، جلدى يهكه م، 1935. 50.صديق بؤرهكهيى(صفى زاده): دوره هفتوانه(سـرنجام) كتابخانهى گُهورى، تهران 1361.

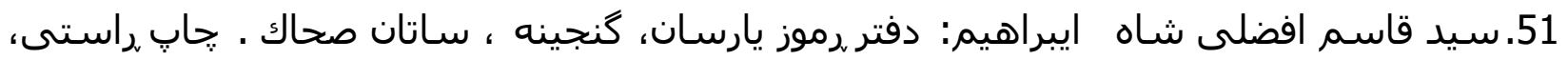
تهران. 52.هاشه رضى: اوستا، ترجمه و تحقيق، سازمان انتشارات فروهر، جايخانه ى خواجه، ؛حاب اول

53. نعمت الله جيحون ابادى: شاهنامهى حقيقت، باهتمام دكتر محد مكرى، تهران 1345. 


\section{REFERENCES}

Abadi, H. N. J. (1250). Reality Shahnama, Qismat Iranshnacy, Dr. Mohammed Mokri Investigation, Paris.

Abadi, N. J. (1345). Shahnama of Reality, supervised by Dr. Mohamad Mukri, Tehran.

Abdulsamad, N. (2012). Gulshan Explanation.

Ahmed, A. Q. (1989). Some Kurdology Subjects, Sweden, first edition.

Ahmed, M. A. (2006). Work Gardankiedin in Pahlawi and Kurdish Languages. Erbil.

Askari, M. (1983). A Review from Haqa Movement, Baghdad.

Azizimi, K. (2017). Sheizim History in Kurdistan, Tehran.

Bag, T. W. (2010). The Remains of Mani Religion, translated by: Sheikh Burhan Barzinji, first edition, Roshnbiri Press.

Bahmani, H. R. (2003). Hawraman News, second edition, Slemani, Hawraman Cultural Center.

Baqi, M. H. (2009). History of Kurdish Music/ third Edition.

Burakayi, S. (Safi Zada), (1361).Dura Haftwana (Saranjam). Kahuri bookshop, Tehran.

Burkayi, S. (Safi Zada), (2001). The Kakayis and their Origin, first edition, Minstry of Culture.

Burkayi, S. (Safa Zada). (2008). History of Kurdish Literature. Erbil, Aras.

Dabbaghi, A. (1987). Some Lines from History, first part, Karwan.

Evanova, N. (2003). The Followers of Reality, kurdistan yaran, (Ahli Haq), translated by: Aso Karim, Erbil.

Ezidi, M. (2006). A Summary about the Kurds. Sardam Press.

Fattah, S. (1969). The Ezidian and Ezidi Religion, Slemani.

Frants, K. (2008). The Secrets of Mitrayi Religion, translated by: Farhad a. Khoshnaw, Erbil, Mokrian.

Grenbrok, P.; Alison, C. (2008). Heritage and Kurdish Identity. Trans. by Wrya Rayhani, Erbil, Mokriani Foundation.

Hawrami, M. A. (1984). Kakayi. Baghdad.

Hawrami, N. (2011). Woman Text in Yarsan Books. Erbil.

Husaini, S. M. (1382).Great Dewana, Kimanshah.

Ibrahim, S. Q. A. S. (1961). The Symbolic Book of Yarsan, Ganjina, satan shak, Rasti press, Tehran.

Kakayi, F. (2009). Religiosity. Lebanon Press.

Kakayi, F. (2013). A Gate to Introduce Yarsan Religion. Bas Newspaper No. 126.

Kakayi, F. (1998). Yarsan. Yarsan Magazine, No. 1.

Kakayi,F. (2012). Islamic \& Religious Education.

Kakayi, H. (1986). Hijri dada Kakayi, Erbil, Karwan.

Kakayi, F. (2011). Yarsan Religion.

Kakayi, F. (2012). Yarsan Religion. 
Khaznadar, M. (2010). History of Kurdish Literature. Part 1. Erbil, Aras.

Mahmood, H. K. (2006). Kurdistan in Islamic Victories, Slemani.

Minorski, V. (2005). Ahli Haq, translated by: Najati Abdullah Mokryan Foundation.

Miran, R. (2017). Religious and National Conduct in Kurdistan, third edition.

Mohammed, M. (1986). A Branch of the Languages Sources, Nusari Kurd, Baghdad.

Mokriani, H. (1991). Hambana Borina Culture, Tehran.

Muddaris, M. A. (1961). Mawlawi Divan, Baghdad.

Muradi, G. (1990). Nigaha Guzaraby Ahl Haq history of Yarsan. Sweden.

Muradi, G. (2010). World Olakan. Nasir Razazi, Erbil, Aras.

Nabaz, J. (1976). The United Kurdish Language, Bamburg.

Nabaz, J. (1986). A Glance to Kurdish Methodology, Kurd Academi, Stockholm.

Nabaz, J. (2009). Philosophy and Thoughts of Yarsan. Nara Press, Erbil.

Naqishbandi, A.S. A. (1985). What is Sophism?, Baghdad.

Quran, Islamic Holy Book. Translated by: Momammed Salih Ibrahimi.

Quran, Islamic Holy Book. Translated by: Hazhar Mokriani..

Rashid, B. H. (2003). Hawraman News, second edition, Slemani.

Ramzyari, M. Q. (1379). Accumulation and Writing, Kimanshah.

Rasool, E. M. (1985). Sophism in Kurdish Poetry New Culture.

Redha, H.O. (1371).Translated by Fruhar Foundation, Khawaja press, first edition.

Rostam, A. (2006). A Historical and Religious Investigation about Kakayis, Hawraman Cultural Center.

Saranjam Bargabargay (72) Pira. Handwriting.

Saranjam Dawray Barzinja. Handwriting

Saranjam. The Holy Religious Book of Yarsan.

Tahiry, T. (2009): History and Philosophy of Saranjam. Rozhhalat Press.Erbil.

Tahiry, T. (2007). Saranjam Book.

Tahiry, T. (2013). Zabori Haqiqat. Kimanshah.

Taqizada, S. H. (2005). Mani and Its Religion, first edition, Erbil, Minra.

Tigris, G. A. A. (1992). A short History of Kurd and Kurdistan, Sweden.

Todari, S. A. (1970). A Bunch of Hawraman and Mariwan History, (some pages from Nur Alnuwar book), translated by: Mohamad M. Karim, Baghdad.

Vlademir, M. (2006). The Origin of Kurd and Several kurdology Speeches, Bir\& Hoshyari Bureay.

Wahbi, T. (1940). Previous Religion of Kurds, Galawezh No. 11, 12, Baghdad.

Zaki, M. A. (1935). The Summery of Kurd and Kurdistan History, first part.

Zand, K. (1971). Religion and Belief in Kurdistan, first edition, Slemani. 